Florida International University FIU Digital Commons

$11-12-2010$

\title{
Phylogenetics, Conservation, and Historical Biogeography of the West Indian Members of the Adelieae (Euphorbiaceae)
}

Brett Jestrow

Florida International University, bjest001@fiu.edu

DOI: $10.25148 /$ etd.FI10120301

Follow this and additional works at: https://digitalcommons.fiu.edu/etd

\section{Recommended Citation}

Jestrow, Brett, "Phylogenetics, Conservation, and Historical Biogeography of the West Indian Members of the Adelieae (Euphorbiaceae)" (2010). FIU Electronic Theses and Dissertations. 315.

https://digitalcommons.fiu.edu/etd/315 


\title{
FLORIDA INTERNATIONAL UNIVERSITY
}

Miami, Florida

\section{PHYLOGENETICS, CONSERVATION, AND HISTORICAL BIOGEOGRAPHY OF THE WEST INDIAN MEMBERS OF THE ADELIEAE (EUPHORBIACEAE)}

\author{
A dissertation submitted in partial fulfillment of the \\ requirements for the degree of \\ DOCTOR OF PHILOSOPHY \\ in \\ BIOLOGY \\ by \\ Brett Jestrow
}

2010 
To: $\quad$ Dean Kenneth Furton

College of Arts and Sciences

This dissertation, written by Brett Anthony Jestrow, and entitled Phylogenetics, Conservation, and Historical Biogeography of the West Indian Members of the Adelieae (Euphorbiaceae), having been approved in respect to style and intellectual content, is referred to you for judgment.

We have read this dissertation and recommend that it be approved.

Maureen Donnelly

Grenville Draper

Carl Lewis

Jennifer Richards

Javier Francisco-Ortega, Major Professor

Date of Defense: November 12, 2010

The dissertation of Brett Jestrow is approved.

Dean Kenneth Furton

College of Arts and Sciences

Interim Dean Kevin O'Shea

University Graduate School

Florida International University, 2010 


\section{DEDICATION}

This dissertation is dedicated to my family, not to mention the dog. 


\section{ACKNOWLEDGMENTS}

Of course, a big thanks to my mentor and friend, Javier Francisco-Ortega. Thanks to my committee: Dr. M. Donnelly, Dr. G. Draper, Dr. C. Lewis, and Dr. J. Richards. I thank Dr. P. Berry, Dr. B. van Ee, and Dr. F. Jiménez, for their contributions to the Cuban and Dominican collections, their support during the field studies, and for their photographs included in this work. I would like to thank the Presidential fellowship of FIU and the EPA GRO-STAR Fellowship (Number MA-91630201-3 to BJ) for financial support. The Cuban Research Travel Grant and the Judith Evans Parker Travel Scholarship both of FIU, also contributed travel funding to BJ for the research. I thank Dr. N. Harriman for his expertise in botanical Latin and J. J. Figueroa for his botanical illustrations. Also the curators: Dr. R. Vogt (B), Dr. L. Gautier (G), and Dr. J.-N. Labat (P), for their help in sending us the photos of herbarium specimens. I also thank my colleagues: Dr. J. Gutiérrez (HAJB), A. Oberli (J), Dr. G. Proctor (J), and A. Veloz (JBSD) for their help

during my field studies and the arrangement of the required collecting, export, and research permits. My thanks go out to Barbara Maloney and Thomas Beasley from FCAEM of FIU for technical support for this study. 


\begin{abstract}
OF THE DISSERTATION
PHYLOGENETICS, CONSERVATION, AND HISTORICAL BIOGEOGRAPHY OF THE WEST INDIAN MEMBERS OF THE ADELIEAE (EUPHORBIACEAE)

by
\end{abstract}

Brett Jestrow

Florida International University, 2010

Miami, Florida

Professor Javier Francisco-Ortega, Major Professor

The Caribbean Island Biodiversity Hotspot is the largest insular system of the New World and a priority for biodiversity conservation worldwide. The tribe Adeliae (Euphorbiaceae) has over 35 species endemic to this hotspot, representing one of the most extraordinary cases of speciation in the West Indies, involving taxa from Cuba, Hispaniola, Jamaica, and the Bahamas. These species form a monophyletic group and traditionally have been accommodated in two endemic genera: Lasiocroton and Leucocroton. A study based on: (1) scanning electron microscopy of pollen and trichomes, (2) macromorphology, and (3) molecular data, was conducted to reveal generic relationships within this group. Phylogenies were based on parsimony and Bayesian analyses of nucleotide sequences of the ITS regions of the nuclear ribosomal DNA and the non-coding chloroplast DNA spacers $p s b M-t r n D$ and $y c f 6-p c b M$. One species, Lasiocroton trelawniensis, was transferred from the tribe into the genus Bernardia. Of the remaining species, three major monophyletic assemblages were revealed, one was restricted to limestone ares of Hispaniola and was sister to a clade with two monophyletic genera, Lasiocroton and Leucocroton. Morphological, 
biogeographical, and ecological data provided additional support for each of these three monophyletic assemblages. The Hispaniolan taxa were accommodated in a new genus with four species: Garciadelia. Leucocroton includes the nickel hyperaccumulating species from serpentine soils of Cuba, while the rest of the species were placed in Lasiocroton, a genus restricted to limestone areas. The geographic history of the islands as well as the phylogenetic placement of the Leucocroton-alliance, allows the research to include the historical biogeography of the alliance across the islands of the Caribbean based on a dispersal-vicariance analysis. The alliance arose on Eastern Cuba and Hispaniola, with Lasiocroton and Leucocroton diverging on Eastern Cuba according to soil type. Within Leucocroton, the analysis shows two migrations across the serpentine soils of Cuba. Additional morphological, ecological, and phylogenetic analyses support four new species in Cuba (Lasiocroton gutierrezii) and Hispaniola (Garciadelia abbottii, G. castilloae, and G. mejiae). 


\section{TABLE OF CONTENTS}

CHAPTER

PAGE

I. Lasiocroton trelawniensis (Euphorbiaceae), a critically endangered species from the Cockpit Country of Jamaica, belongs to Bernardia (Euphorbiaceae) ....................1

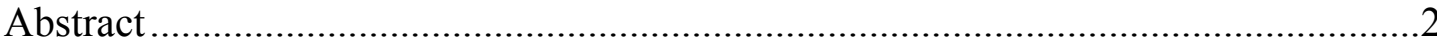

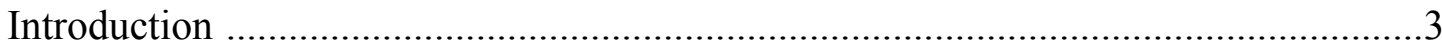

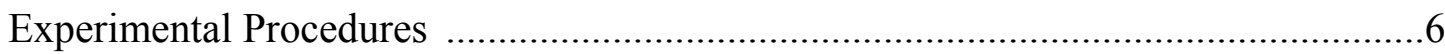

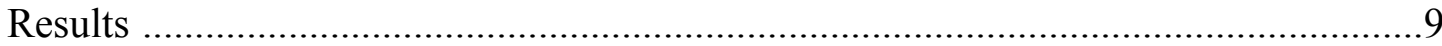

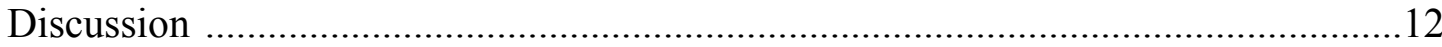

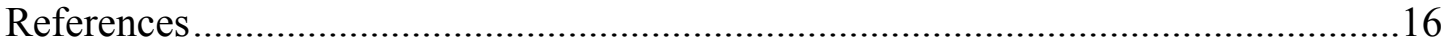

II. The generic delimitations of the Antillean members of tribe Adelieae (Euphorbiaceae) and the description of the Hispaniolan endemic genus

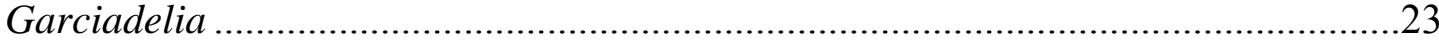

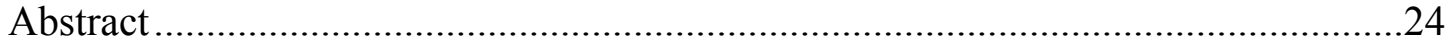

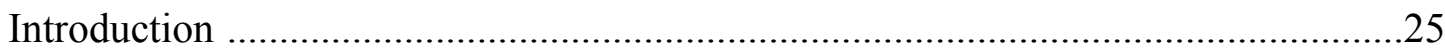

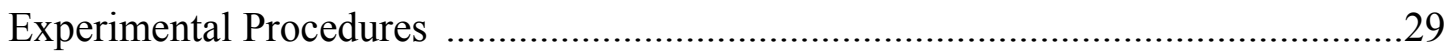

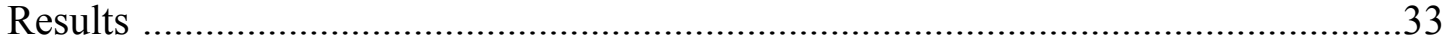

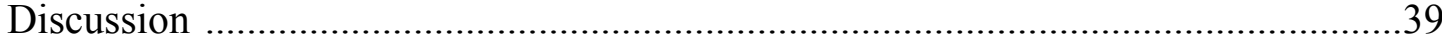

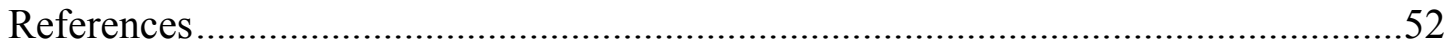

III. Islands within Islands; a Molecular Phylogenetic Study of a Plant Radiation across

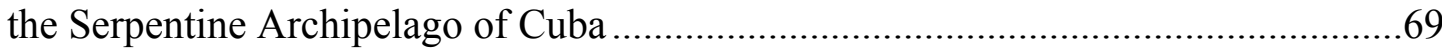

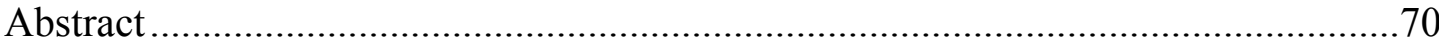

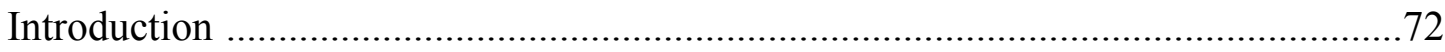

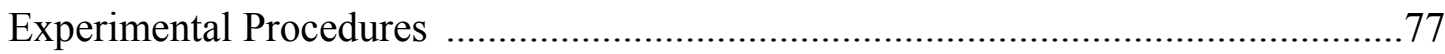

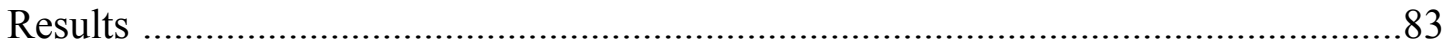

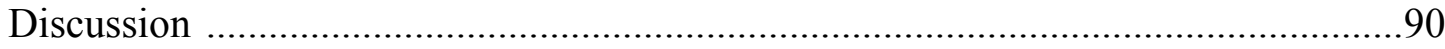

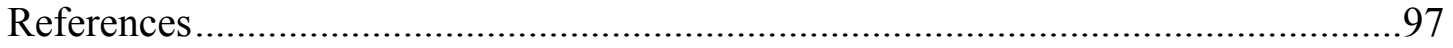

IV. Conclusions and Future Research Directions ..................................................115

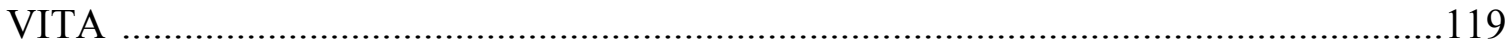




\section{LIST OF TABLES}

TABLE

PAGE

1. Morphological and palynological distinctions between Bernardia and Lasiocroton

2. Parsimony statistics of tree topologies.....

3. Plant Collections: localities, collectors, and genbank numbers

4. Parsimony statistics of trees and characters

5. Bremer's Ancestral Areas Analysis for the Leucocroton alliance clade according to both parsimony and Bayesian topologies

6. The Bremer Ancestral Areas Analysis for the Lasiocroton clade according to both parsimony and bayesian topologies 


\section{LIST OF FIGURES}

FIGURE

PAGE

1. Scanning electron microscopy images for Bernardia trelawniensis and Lasiocroton macrophyllus .20

2. Strict consensus trees for both trnl-f and $r b c L$ DNA regions 21

3. Strict consensus of the comibend cpDNA regions .22

4. One of 14 most parsimonious trees with bootstrap and Bayesian clade credibility values .57

5. Example most parsimonious trees for the two cpDNA datasets; $p s b M-t r n D$ and ycf6-pcbM. .58

6. The single most parsimonious trees for both nuclear and cpDNA regions with bootstrap and Bayesian clade credibility values

7. Scanning electron microscopy images of the Leucocroton alliance. .60

8. Map of Hispaniola showing the known localities of the four species of Garciadelia

9. Map of Cuba showing the known localities for the new species, Lasiocroton gutierrezii

10. Illustration of Lasiocroton gutierrezii

11. Illustration of the four species of Garciadelia .64

12. Photographs of flowering individuals of the Leucocroton alliance 103

13. The nine major ultramafic massifs of Cuba showing the distribution of Leucocroton. .104

14. Geographical distribution of species of Lasiocroton and Garciadelia 105

15. The strict consensus trees of the ITS and combined cpDNA datasets. .106

16. One of the twelve most parsimonious trees from the total combined ITS - cpDNA dataset.

17. Reconstruction of ancestral areas using DIVA area analyses along topologies obtained after phylogenetic analyses of the ITS-cpDNA combined data set 


\section{CHAPTER I}

Lasiocroton trelawniensis (Euphorbiaceae), a critically endangered species from the Cockpit Country of Jamaica, belongs to Bernardia (Euphorbiaceae)

\section{BRETT JESTROW, GEORGE PROCTOR, AND JAVIER FRANCISCO-ORTEGA}

Jestrow, B. (Department of Biological Sciences, Florida International University, University

Park, Miami, FL 33199, U.S.A. (correspondence) and Center for Tropical Plant

Conservation, Fairchild Tropical Botanical Garden, Coral Gables, Miami, FL 33156, U.S.A.;

e-mail: bjest001@fiu.edu), G. Proctor (Department of Life Sciences, Botany, Mona Campus,

Kingston 7, Jamaica; e-mail: proctorbotanist@yahoo.com) \& J. Francisco-Ortega

(Department of Biological Sciences, Florida International University, University Park,

Miami, FL 33199, U.S.A. and Center for Tropical Plant Conservation, Fairchild Tropical

Botanical Garden, Coral Gables, Miami, FL 33156, U.S.A.; e-mail: ortegaj@fiu.edu).

Chapter 1 was published in Botanical Review with the same title and authors. 


\begin{abstract}
A taxonomic study based on scanning electron microscopy of pollen, macromorphology, and a molecular phylogenetic analysis of the chloroplast DNA regions trnL$F$ and $r b c L$ shows that Lasiocroton trelawniensis belongs to the Neotropical genus Bernardia. The main morphological differences between Bernardia and Lasiocroton are given, and the new combination Bernardia trelawniensis is provided.

Key Words: Antilles, Caribbean, conservation, DNA phylogenetics, SEM, West Indies
\end{abstract}




\section{INTRODUCTION}

Conservation without clear knowledge of the taxonomy and phylogenetic status of the target taxa can be deceptive. Phylogenetic reconstructions constitute a necessary aspect of the framework required for assigning conservation priorities (Rodrigues et al., 2005), and phylogenetic trees are fundamental for understanding the taxonomy of endangered species (Sinclair et al., 2005). A species misplaced in a particular genus can have a definite impact on the establishment of conservation and management strategies (Rodrigues et al., 2005). A case in point takes place in the Cockpit Country of Jamaica. This region consists primarily of mesic forest over steep limestone hills and is well known as a major "hot spot" for endemic plant species in the West Indies (Iremonger, 1997). While the Cockpit Country only accounts for $4 \%$ the landmass of Jamaica, approximately $60 \%$ of the island-endemic vascular plants occur in the region (Iremonger, 1997). Lasiocroton Griseb., a genus of euphorbiaceous trees, is diverse on Jamaica, with four of the six species endemic to the island (Adams, 1972). All species found on Jamaica are listed by the IUCN (2007) from the Endangered (E) to the Lower Risk (LR) categories. Lasiocroton trelawniensis C.D. Adams, the species of discussion for this paper, is endemic to a single hilltop, "Island View Hill," in the Cockpit Country (Adams, 1970), and I consider it to be in the Critically Endangered category (CR, based on criteria B1 + D, i.e. present from only one locality with a population size estimated to number fewer than 50 mature individuals) of the red list guidelines of the World Conservation Union (IUCN, 2001). Lasiocroton trelawniensis was incorrectly assigned to the Endangered category by the IUCN (2007). 
Webster (1994) placed Lasiocroton in the tribe Adelieae s.l. (subfamily Acalyphoideae) on the basis of morphology. Recently, Wurdack et al. (2005) and De-Nova et al. (2006) published molecular phylogenies of the Euphorbiaceae. The study by Wurdack et al. (2005) focused on the chloroplast regions $r b c L$ and $\operatorname{trn} L-F$ and proposed a new circumscription for the Acalyphoideae s.s. This subfamily has two major lineages, named as the "core acalyphoids" and the "alchorneoids." The core acalyphoids comprise eight distinct clades, which were labeled from A1 to A8. Lasiocroton belongs to A6, and this clade is sister to a monophyletic assemblage composed of Clades A7 and A8. Clade A5 is sister to the group formed by Clades A6, A7, and A8. The genus Bernardia belongs to Clade A7. (Fig. 3.).

These previous molecular studies also changed the tribal placements of some genera within the Acalyphoideae. The tribe Adelieae no longer contains the genera Enriquebeltrania Rzed. and Crotonogynopsis Pax, results also supported by palynological data (Nowicke et al., 1999). The removal of these two genera restricts the Adelieae to the New World. Philyra Klotzsch, a monotypic South American genus treated by Webster (1994) in the tribe Chrozophoreae subtribe Ditaxinae, was found to be closely allied to the Adelieae. Therefore I consider the Adelieae s.s. to include four genera: Adelia L., Lasiocroton, Leucocroton Griseb., and Philyra. These genera form a monophyletic group, which represent half of the genera of Clade A6 from Wurdack et al. (2005). In addition, I also propose that Adenophaedra (Müll. Arg.) Müll. Arg., Bernardia Houst. ex Mill., and Caryodendron H. Karst. comprise the tribe Bernardieae s.s. (Clade A7 from Wurdack et al., 2005). These two tribes, as recognized in my study, are strongly supported by bootstrap values higher than 95\% (Wurdack et al., 2005). However, certain representatives of the two 
tribes are morphologically similar, exemplified by the lectotype of Bernardia was initially described as Adelia bernardia L. For example, recently Adelia cinera (Wiggins \& Rollins) A. Cerv., V. W. Steinm. \& Flores Olvera was moved from Bernardia (Cervantes et al., 2003).

As part of an ongoing project on the systematics of the West Indian genera Lasiocroton and Leucocroton, I investigate the taxonomic placement of Lasiocroton trelawniensis based on morphological, palynological, and DNA evidence. My study shows that this Jamaican endemic does not belong to the Adelieae, but to the Bernardieae where I have placed in Bernardia, a neotropical genus with approximately 70 species (RadcliffeSmith, 2001) and seven sections (Müller Argoviensis, 1866; Pax and Hoffman, 1912). Pax and Hoffman (1912) provided the most recent published taxonomic treatment for this genus. Hereafter, I will refer to this species as B. trelawniensis (see taxonomic treatment below).

The lectotype of this genus is Bernardia carpinifolia Griseb. (= B. dichotoma (Willd.) Müll. Arg.) (Webster, 1994), and the description was published by Grisebach in the $19^{\text {th }}$ century (Grisebach, 1859). Later Müller Argoviensis (1866) published B. dichotoma, based on the earlier name Croton dichotomus Willd. (Willdenow, 1805). Bernardia dichotoma is the name currently used in the West Indian Floras and B. carpinifolia is considered a synonym (e.g., Adams, 1972; Correll and Correll, 1982; Howard, 1989; Liogier, 1953, 1986; Liogier and Martorell, 2000). The type species is endemic to the Caribbean Islands, and it belongs to the section Tyria (Klotzsch) Müll. Arg., a taxon with 26 species (Cervantes, 2006). Because this section includes the type of the Bernardia, according to the rules of botanical nomenclature, I will refer to this taxon as section Bernardia. Pax and Hoffman 
(1912) morphologically differentiated this group as shrubs having an indumentum with stellate or fasciculate trichomes, glandulous receptacles, and lacinulate-lacerate styles.

\section{MATERIALS AND METHODS}

Pollen Study. Pollen from Bernardia trelawniensis and Lasiocroton macrophyllus (Sw.) Griseb. was removed from herbarium specimens collected in the wild in Jamaica (B. trelawniensis: Jestrow 1004 (FTG); L. macrophyllus: Jestrow 1003 (FTG) and studied with Scanning Electron Microscopy (SEM) in the Florida Center for Analytical Electron Microscopy (FCAEM) of Florida International University (FIU) using the instrument JEOL JSM 5900LV. Untreated pollen was coated with gold-palladium using a SPI-Module Sputter Coater at $367 \AA$ for four minutes. Although pollen for other species of Bernardia were not examined in my study, I made comparisons with SEM images previously published by Nowicke et al. (1999) and Takahashi et al. (2000).

DNA Study. My study includes a phylogenetic analyses of nucleotide sequences of the chloroplast regions $r b c L$ and $t r n L-F$, and uses both data available in GenBank and published by Wurdack (2005), as well as new nucleotide sequences generated for this study. The ingroup included all the sequences available from GenBank for those taxa placed in Clades A6, A7, and A8 of the "core acalyphoid" group as defined by Wurdack et al. (2005) (24 species in 20 genera for $t r n L-F$, and 19 species in 18 genera for $r b c L$ ). The sequence of Bernardia available for the trnL-F in GenBank is for B. scabra Müll. Arg., but it only had the half of the 3' end. The Bernardia GenBank (GB) sequence for $r b c L$ is for B. myricifolia (Scheele) Watson. The ingroup had the following sequences obtained by us. For $r b c L$ : Bernardia dichotoma (GB: EF470580; Jestrow 1001 (FTG)) and B. trelawniensis (GB: 
EF470579; Jestrow 1004 (FTG)). For trnL-F: Bernardia dichotoma (GB: EF470582 and EF470584; Jestrow 1001 (FTG)), B. myricifolia (GB: EF470581 and EF470583; Barron S. Rector 335 (FTG)), and B. trelawniensis (GB: EF107750 and EF107751; Jestrow 1004 (FTG)).

I was unable to sample broadly within Bernardia. However I included Bernardia dichotoma. The lectotype of the genus (B. carpinifolia) is a synonym of B. dichotoma. My Bernardia sampling further included B. myricifolia, a species also belonging to section Bernardia with B. dichotoma. Bernardia scabra belongs to section Polyboea (Klotzsch) Müll. Arg. and was included in my analyses in order to have in my ingroup as many species as possible for this genus. The outgroup included two species (Seidelia triandra (E. Mey.) Pax and Leidesia procumbens (L.) Prain), belonging to Clade A5 (as defined by Wurdack et al. (2005)); based on previous phylogenetic studies this group is sister to all the genera of the ingroup (Wurdack et al. 2005). The nucleotide sequences of the outgroup were also retrieved from Wurdack et al. (2005) via GenBank.

Plant DNA was extracted from silica-dried material using a Qiagen DNeasy Plant Mini kit. PuReTaq Ready-To-Go PCR beads were used for the PCR amplification reaction mix. For both regions the cycle program is as follows: $80^{\circ} \mathrm{C}: 5 \mathrm{~min},\left(94^{\circ} \mathrm{C}: 1 \mathrm{~min}, 50^{\circ} \mathrm{C}: 1\right.$ $\left.\min , 72^{\circ} \mathrm{C}: 2 \mathrm{~min}\right) \times 35,72^{\circ} \mathrm{C}: 5 \mathrm{~min}$. The $\operatorname{trn} L-F$ amplification was obtained from four primers in two separate fragments because of difficulties in amplifying the region as a whole. The first fragment was amplified using primers "c" and "d" from Taberlet et al. (1991). Primers "e" and "f" were used to amplify the second fragment (Taberlet et al, 1991). The $r b c L$ amplification was obtained using forward primer, rbcL RH1, and reverse primer, rbcL 3'ZC (Zurawski and Clegg, 1987). Cycle sequencing was performed in both directions with 
the ABI PRISM ${ }^{\mathrm{TM}}$ BigDye $^{\mathrm{TM}}$ v.3.1 Terminator Cycle Sequencing Kit (Perkin Elmer) following the manufacturers instructions. The primers used for PCR amplification were also utilized for the cycle sequencing reactions. Nucleotide sequences were visualized on a PE Applied Biosystems 377 automated sequencer at the Florida International University (FIU) DNA Core Facility.

All sequences were assembled and visually aligned, using Sequencher 3.1.1 (Gene Codes, Michigan). Both regions, $r b c L$ and $\operatorname{trn} L-F$, were found to be alignable and no regions were omitted in the analysis. Maximum Parsimony analysis was performed using PAUP* 4.0b10 (Swofford, 2003) using the heuristic algorithm with equal weights and unordered characters, tree-bisection-reconnection (TBR) swapping, and MulTrees “on." Gaps were coded as uninformative. Phylogenetic support for each clade was evaluated through bootstrap analysis (Felsenstein, 1985) using 100 replicates in PAUP* with the same settings, except MulTrees was set to "off" in order to shorten calculation time for both the trnL-F and combined bootstrap analyses. Consistency index (CI; excluding uninformative characters) and retention index (RI) were also calculated (Kluge and Farris, 1969; Farris, 1989).

I conducted three different phylogenetic analyses, the first based on the $r b c L$ data matrix (23 taxa), the second one on the trnL-F data set (29 taxa), and the third one on a combined matrix that included data from $t r n L-F$ and $r b c L$. The combined analyses only included those species for which data were available for both markers (22 taxa), with the only exception being for the genus Dysopsis Baill. As the genus Dysopsis included different species for the $r b c L$ and the trnL-F analyses, the sequences from the two different species were combined as Dysopsis sp. for the combined analysis. This approach was also followed by Wurdack et al. (2005). I feel this is justified given the very close associations of the two 
taxa, both were historically considered varieties of the same species, and presently some authorities consider Dysopsis to be a monotypic genus (Radcliffe-Smith, 2001). Also for the combined analysis, both the $r b c L$ and $t r n L-F$ regions for each taxa were included with equal weighting according to individual base characters.

\section{RESULTS AND DISCUSSION}

Pollen Data. Bernardia trelawniensis has a punctate tectum with a psilate surface and lacks an operculum (Fig. 1). These are characteristics of Bernardia pollen that are not known to occur in Lasiocroton (Nowicke et al., 1999; Takahashi et al., 2000). In contrast, the pollen of Lasiocroton is strikingly different with both a fusiform operculum and a crotonoid tectum (Fig. 1, Table 1). Additional distinctive micromorphological features previously recorded by Nowicke et al. (1999) and Takahashi (2000) (i.e., margo and costa ectocolpi) are also indicated in Table 1. The presence or absence of margo and costa ectocolpi of B. trelawniensis were not observed. Nowicke et al. (1999) included nine species of Bernardia and Takahashi et al. (2000) included three species of Lasiocroton, allowing for robust confidences in their conclusions about pollen structure. The palynological data clearly supports the placement of my target species in Bernardia and not in Lasiocroton.

\section{Molecular phylogenetic data--}

$\boldsymbol{r b c L}$. The final aligned matrix for the $r b c L$ parsimony analysis was 1446 nucleotide characters in length. There were 137 variable characters, with 54\% (74) of these parsimonyinformative. This phylogenetic analysis yielded 64 most-parsimonious trees of 230 steps each $(\mathrm{CI}=0.5409 ; \mathrm{RI}=0.7137)$. The strict consensus of the 64 most parsimonious trees is 
shown in Fig. 2. Bernardia trelawniensis forms a polytomy with the other two species of Bernardia included in the analyses, with $100 \%$ bootstrap support.

trnL-F. The final aligned matrix for the trnL-F parsimony analysis had 1419 nucleotide characters. There were 319 variable characters, with $42 \%$ (135) of these being parsimony-informative. The parsimony analysis yielded 18 most-parsimonious trees of 433 steps each $(\mathrm{CI}=0.7031 ; \mathrm{RI}=0.8455)$. The strict consensus of all 18 most parsimonious trees is shown in Fig. 2. The strict consensus shows Bernardia trelawniensis as sister to $B$. dichotoma with bootstrap support of $83 \%$, and this clade is sister to B. myricifolia (bootstrap support of $90 \%)$.

The trnL-F study also has some additional phylogenetic implications for the family. Wurdack et al. (2005) showed that the tribe Bernardieae s.s. (Clade A7) to form a strongly supported monophyletic group after the phylogenetic analyses of the $r b c L$ data alone and of the combined $r b c L$ and $t r n L-F$ data set. However, the trnL-F phylogeny obtained by Wurdack et al. (2005) weakly supported the recognition of the tribe Bernardieae s.s. (Clade A7 after Wurdack et al. (2005)) with a bootstrap value of 59\%. However, my phylogeny with the inclusion of three complete Bernardia sequences increased the support for this clade (to 96\%). Therefore my molecular analysis provides additional strong support for the recognition of this tribe.

Combined: The parsimony analysis yielded tree of 582 steps $(\mathrm{CI}=0.6347$; RI $=$ 0.7794). This tree is shown in Fig. 3. The three Bernardia species in the analysis form a monophyletic clade with a bootstrap of $100 \%$. The combined analysis nests Bernardia trelawniensis into Bernardia sect. Bernardia with a bootstrap value of 73\%. The molecular data support the palynological results of placing Bernardia trelawniensis within Bernardia 
and also provide additional support for the phylogenetic conclusions of Wurdack et al. (2005).

Morphological evidence. During my initial field studies in Jamaica (May 2005), I noticed morphological features that were in conflict with the placement of Bernardia trelawniensis in the Antillean genus Lasiocroton (Radcliffe-Smith, 2001; Webster, 1994). Bernardia trelawniensis has leaves with denticulate margins, whereas, all other species in Lasiocroton have leaves with entire to sinuate margins (Radcliffe-Smith, 2001; Webster, 1994). In fact, no species has leaves with denticulate margins in the tribe Adelieae s.s. (Webster, 1994; Radcliffe-Smith, 2001). The only species in the Adelieae s.s. with leaves even approaching denticulation is the widespread Antillean L. bahamensis Pax \& K. Hoffm., with some individuals from Cuba having sinuate leaves. In addition, a single pistillate flower was found on a primarily staminate plant of B. trelawniensis, and it is known that monoecy occurs in Bernardia but not in Lasiocroton (Radcliffe-Smith, 2001; Webster, 1994).

My initial morphological observations for Bernardia were supplemented by those provided by Radcliffe-Smith (2001) and Cervantes et al. (2003). I also found additional morphological characters that show that this taxon belongs to Bernardia (Table 1). All species of Bernardia have glands near the base of the leaf whereas no species in the Adelieae s.s. have glands on their leaves. Bernardia trelawniensis has glands numbering from one to three, though these glands are not obvious, particularly on immature leaves. Furthermore, the glands exhibited by B. trelawniensis, are abaxial on the lamina and quite flat which is typical for Bernardia sect. Bernardia. The glandular condition is quite different from that of B. corensis (Jacq.) Müll. Arg. of sect. Polyboea which has a pair of tuberculate glands at the joining of the lamina and petiole. In addition, Bernardia species have stipules, while 
Lasiocroton species are exstipulate. Bernardia trelawniensis has small, 1-2 mm long subulate stipules, similar to other members of Bernardia sect. Bernardia.

Trichomes also provide important diagnostic characters. Bernardia trelawniensis has strikingly stellate trichomes, densely arranged with long, erect and narrow radii of a glasslike appearance. Lasiocroton, which literally translates to "wooly croton," has stellate trichomes with thick and rugose radii that are typically brown in color. No species of Lasiocroton has trichomes similar to those of $B$. trelawniensis. While not all species of Bernardia have such trichomes, stellate trichomes are typical of Bernardia sect. Bernardia. Plants of B. trelawniensis have staminate flowers born on a short $(5-10 \mathrm{~mm})$ spicate inflorescence. In contrast, the staminate inflorescence of Lasiocroton is racemose to subpaniculate with a rachis ranging from 5 to $25 \mathrm{~cm}$. Three additional floral structures (i.e., anthers, male disk glands, and pistillodes) also have consistent differences between the two genera. The main morphological features that distinguish Lasiocroton from Bernardia are listed in Table 1. These two genera are readily distinguishable, even from sterile specimens, on the basis of several morphological features.

\section{TAXONOMIC IMPLICATIONS}

One reason Bernardia trelawniensis was assigned to Lasiocroton is because the original description only included pistillate specimens (Adams, 1970). Male specimens provide the most obvious characters to distinguish the two genera. In addition, $B$. trelawniensis has some general features found in species of Lasiocroton. Traits shared by these two taxa include a pronounced abaxial leaf venation, a yellowish indumentum on recent 
growth, flowers with a single whorl of perianth, pistillate inflorescences of similar length and structure, a woody habit, and technically "stellate trichomes."

My morphological observations suggest that Bernardia trelawniensis is closely related to the type species of the genus. I am aware that my phylogenetic analyses had limited sampling within Bernardia, and that future studies might prove this genus not to be monophyletic. Two sections of Bernardia, Passaea (Baill.) Müll. Arg. and Traganthus (Klotzsch) Müll. Arg. were not included in my study, both have been suggested to possibly warrant generic status because of their unique morphologies (Webster, 1994; RadcliffeSmith, 2001). As the morphology of the genus is not clearly understood, I cannot rule out the possibility of the paraphyly of Bernardia. However, even if future studies find Bernardia to be paraphyletic, B. trelawniensis will still remain part of Bernardia s.s. because of the species morphological similarities to the type species of this genus.

Bernardia dichotoma is widely distributed on the Caribbean Islands (Correll and Correll, 1982; Liogier, 1953, 1986). After a preliminary study of specimens of B. dichotoma from Jamaica, the consistent traits that differentiate these two species are trichome density and color. The trichomes of B. dichotoma growing on Jamaica are dense and give a tomentose appearance with a whitish hue. In contrast, B. trelawniensis has significantly fewer trichomes of a yellowish hue. Cervantes (2006) included only one variety of $B$. dichotoma in her thesis and suggested that the species boundaries of B. dichotoma are not well established. However, on Jamaica, B. trelawniensis is readily identifiable from B. dichotoma on the basis of my own observations in the field and of herbarium specimens.

Bernardia dichotoma seems to represent a taxonomic complex with a poorly understood morphology, and I cannot rule out that B. trelawniensis could be a part of this 
complex. As Pax and Hoffman (1912) distinguished three varieties of B. dichotoma, clearly further research is needed to interpret morphological variation within B. dichotoma and its implications for the relationship between B. trelawniensis and B. dichotoma.

Bernardia trelawniensis is Critically Endangered because of its precarious locality, thus placing the species at the forefront of conservation importance. A recent botanical expedition (2006) to the Cockpit Country, headed by Fairchild Tropical Botanic Garden, found the species growing on all elevations of Island View Hill but identified less than 50 individuals (Lauren Raz, pers. comm.). These additional field observations further support that B. trelawniensis is Critically Endangered.

The phylogenetic component of this paper has no impact on the assignment of Critically Endangered according to the guidelines of the IUCN. However, the phylogeny would have an impact on management strategies, if these trategies were based on phylogenetic diversity. The conservation priority of a species closely related to a widespread species has a lower quantitative value of phylogenetic diversity when compared to a species with a highly differentiated morphology belonging to a restricted endemic genus (Rodrigues et al., 2005). This means, that while Bernardia trelawniensis was thought to have an unusual evolutionary history in Lasiocroton -with denticulate margins, glands, and stipules as autapomorphies- now the total amount of evolutionary change has been reduced by it placement in the morphologically similar Bernardia. Bernardia trelawniensis is Critically Endangered, but no longer has the prestige of being the only denticulate, glandular, and stipulate member of its genus. 


\section{TAXONOMIC TREATMENT}

Bernardia trelawniensis (C.D. Adams) Jestrow \& G. R. Proctor, comb. nov. Lasiocroton trelawniensis C.D. Adams, Phytologia 20(5): 312. 1970. TYPE: JAMAICA, Trelawny Parish, 1.5 miles north of Warsop, Wilson Valley District, Island View Hill, collected on wooded limestone hilltop, 2000-2200 feet, 26 Mar 1960, G.R. Proctor 20746 (holotype IJ).

Additional specimen examined. JAMAICA. Trelawny Parish: 1.5 miles north of Warsop, Wilson Valley District, Cockpit Country, Island View Hill, limestone hilltop, 670m, 18¹7’13.8’N, 77³4’33.3”W, Jestrow 1004 (FTG).

\section{SPECIES DESCRIPTION}

Shrubs 1-4 m tall, dioecious with occasional deviations to monoecy, indumentum with stellate trichomes, latex absent. Leaves alternate, simple, elliptic to lanceolate, shortly rounded at base, glands numbering from 1-3 placed abaxially near base of lamina, lamina 3$10 \mathrm{~cm}$ long and 1-4 cm wide, denticulate margins, penninerved, prominent abaxial reticulatepinnate venation, developing leaves yellowish abaxially, petiole $0.5-1 \mathrm{~cm}$ long. Subulate stipules 1-2 mm long. Staminate inflorescence spicate, axillary, 4-6 mm long. Staminate flowers with single whorl of poorly defined perianth, 5-merous perianth $\sim 1 \mathrm{~mm}$ long. Pistillate inflorescence as terminal racemes, erect in fruit, 3-6 cm in length, 5-11 flowers, flowers sessile. Pistillate flowers with a persistent single whorl of 5-merous perianth $\sim 2 \mathrm{~mm}$ long. Fruits 3-sectioned schizocarps, oblong-globose, 6-8 mm long, olive-green, tawnytomentose. 


\section{LITERATURE CITED}

Adams, C. D. 1972. Flowering plants of Jamaica. The University Press, Glasgow.

Adams, C. D. 1970. Miscellaneous additions and revisions to the flowering plants of Jamaica. Phytologia 20: 312-313.

Cervantes, A., V. W. Stienmann \& H. F. Olvera. 2003. Adelia cinera (Euphorbiaceae), formerly in Bernardia. Brittonia. 55: 4-9.

Cervantes, A. 2006. Sistemática de Bernardia sección Tyria (Euphorbiaceae). Doctoral Thesis, Instituto de Biología, UNAM, Mexico.

Correll, D. S. \& H. B. Correll. 1982. Flora of the Bahama Archipelago. A.R. Ganter Verlag KG, Vaduz, Florida.

De-Nova, J. A., V. Sosa \& K. J. Wurdack. 2006. Phylogenetic relationships and the description of a new species of Enriquebeltrania (Euphorbiaceae s.s.): An enigmatic genus endemic to Mexico. Syst. Bot. 31: 533-546.

Farris, J. S. 1989. The retention index and homoplasy excess. Syst. Zool. 38: 406-407.

Felsenstein, J. 1985. Confidence limits of phylogenies: an approach using bootstrap. Evolution 39: 783-791.

Grisebach, A. H. R. 1859. Flora of the British West Indian Islands. Lovell Reeve \& Co., London.

Howard, R. A. 1989a. Flora of the Lesser Antilles, Vol. 5. Arnold Arboretum, Harvard University, Jamaica Plain, Massachusetts.

Iremonger, S. 1997. Cockpit Country, Jamaica. Pp. 266-268. In: S. D. Davis, V. H. Heywood, O. Herrera-MacBryde, J. Villa-Lobos, \& A. C. Hamilton, (eds.), Centres of Plant Diversity vol 3. WWF \& IUCN, IUCN Publications Unit, Cambridge, UK.

IUCN. 2001. IUCN red list categories and criteria: Version 3.1. IUCN Species Survival Commission. IUCN, Gland, Switzerland and Cambridge, UK. Published in the Internet: http://www.redlist.org/info/categories_criteria2001.

IUCN. 2007. 2007 IUCN red list of threatened species. IUCN Species Survival Commission. IUCN, Gland, Switzerland and Cambridge, UK. Published on the Internet: http://www.iucnredlist.org. 
Kluge, A. G. \& J. S. Farris. 1969. Quantitative phyletics and the evolution of anurans. Syst. Zool. 18: 1-32.

Liogier, A.H. 1953. Flora de Cuba, Vol. 3. Contr. Ocas. Mus. Hist. Nat. Colegio "De La Salle" 13: 1-502.

Liogier, A.H. 1986. La Flora de la Española. Vol. 4. Universidad Central del Este, San Pedro de Macorís, Dominican Republic.

Liogier, A.H. \& L. F. Martorell. 2000. Flora of Puerto Rico and adjacent islands. Segunda Edición Revisada. Editorial de la Universidad de Puerto Rico, Río Piedras, Puerto Rico.

Müller Argoviensis, J. 1866. Euphorbiaceae (excluding Euphorbia). In: A. De Candolle. (ed.), Prodomus Systematis Naturalis Regni Vegetabilis vol 15 (2): 189-1260. Victoris Masson et Filii, Paris.

Nowicke, J. W., M. Takahashi \& G. L. Webster. 1999, Pollen Morphology, exine structure, and systematics of Acalyphoideae (Euphorbiaceae). Part 2. Rev. Palaeobot. Palynol. 105: 1-62.

Pax, F. \& K. Hoffman. 1912. Euphorbiaceae. In: A. Engler. (ed.), Das Pflanzenreich. Vol. 4 (147- VI): 21-42.

Radcliffe-Smith, A. 2001. Genera Euphorbiacearum. Royal Botanic Gardens, Kew.

Rodrigues, A. S. L., T. M. Brooks \& K. J. Gaston. 2005. Integrating phylogenetic diversity in the selection of priority areas for conservation: does it make a difference? Pp. 101-119. In: A. Purvis, J. L. Gittleman \& T. Brooks (eds.), Phylogeny and conservation. Cambridge University Press, Cambridge.

Sinclair, E. A., M. Pérez-Losada \& K. A. Crandall. 2005. Molecular phylogenetics for conservation biology. Pp. 19-56. In: A. Purvis, J. L. Gittleman \& T. Brooks (eds.), Phylogeny and conservation. Cambridge University Press, Cambridge.

Swofford, D. L. 2003. PAUP*: phylogenetic analysis using parsimony (*and other methods), version 4. Sinauer, Sunderland, Massachusetts.

Taberlet, P., L. Gielly, G. Pautou \& J. Bouvet. 1991. Universal primers for amplification of three non-coding regions of chloroplast DNA. Pl. Molec. Biol. 17: 1105-1109.

Takahasi, M., J. W. Nowicke, G. L. Webster, S. S. Orli \& S. Yankowski. 2000. Pollen morphology, exine structure, and systematics of Acalyphoideae (Euphorbiaceae). Part 3. Rev. Palaeobot. Palynol. 110: 1-66. 
Webster, G. L. 1994. Synopsis of the genera and suprageneric taxa of Euphorbiaceae. Ann. Missouri Bot. Gard. 81: 33-144.

Wurdack, K. J., P. Hoffmann, \& M. W. Chase. 2005. Molecular phylogenetic analysis of uniovulate Euphorbiaceae (Euphorbiaceae sensu stricto) using plastid $r b c L$ and trnL-F DNA sequences. American Journal of Botany 92: 1397-1420.

Zurawski, G. \& M. T. Clegg. 1987. Evolution of higher plant chloroplast DNA encoded genes: implications for structure function and phylogenetic studies. Annual Rev. Pl. Physiol. Pl. Molec. Biol. 38: 391-418. 
TABLE 1

MORPHOLOGICAL AND PALYNOLOGICAL DISTINCTIONS BETWEEN Bernardia AND Lasiocroton, ADAPTED FROM CERVANTES ET AL. (2003) AND JESTROW

(UNPUBLISHED)

\begin{tabular}{|c|c|c|}
\hline & Bernardia & Lasiocroton \\
\hline \multicolumn{3}{|l|}{ Leaf } \\
\hline Glands & present & absent \\
\hline Margin & dentate & entire to sinuate \\
\hline Stipules & present & absent \\
\hline Trichomes & simple, fasciculate, stellate & rugose-stellate \\
\hline \multicolumn{3}{|l|}{ Flower } \\
\hline Anthers & basifixed & subdorsifixed \\
\hline Male disk glands & interstaminal or none & annular \\
\hline Pistillode & absent & filiform or absent \\
\hline \multicolumn{3}{|l|}{ Infloresence } \\
\hline Pistillate infloresence & racemose to spicate & racemose to subpaniculate \\
\hline Pistillate rachis length & $1 \mathrm{~mm}$ to $20 \mathrm{~cm}$ & $5 \mathrm{~cm}$ to $25 \mathrm{~cm}$ \\
\hline \multicolumn{3}{|l|}{ Pollen } \\
\hline Operculum & absent & fusiform \\
\hline Tectum & punctate to reticulate & crotonoid \\
\hline Costa ectocolpi & present & absent \\
\hline Margo & present & absent \\
\hline
\end{tabular}


FIG. 1. Pollen SEM. A. Bernardia trelawniensis (From Jestrow 1004). B. Lasiocroton macrophyllus (From Jestrow 1003).

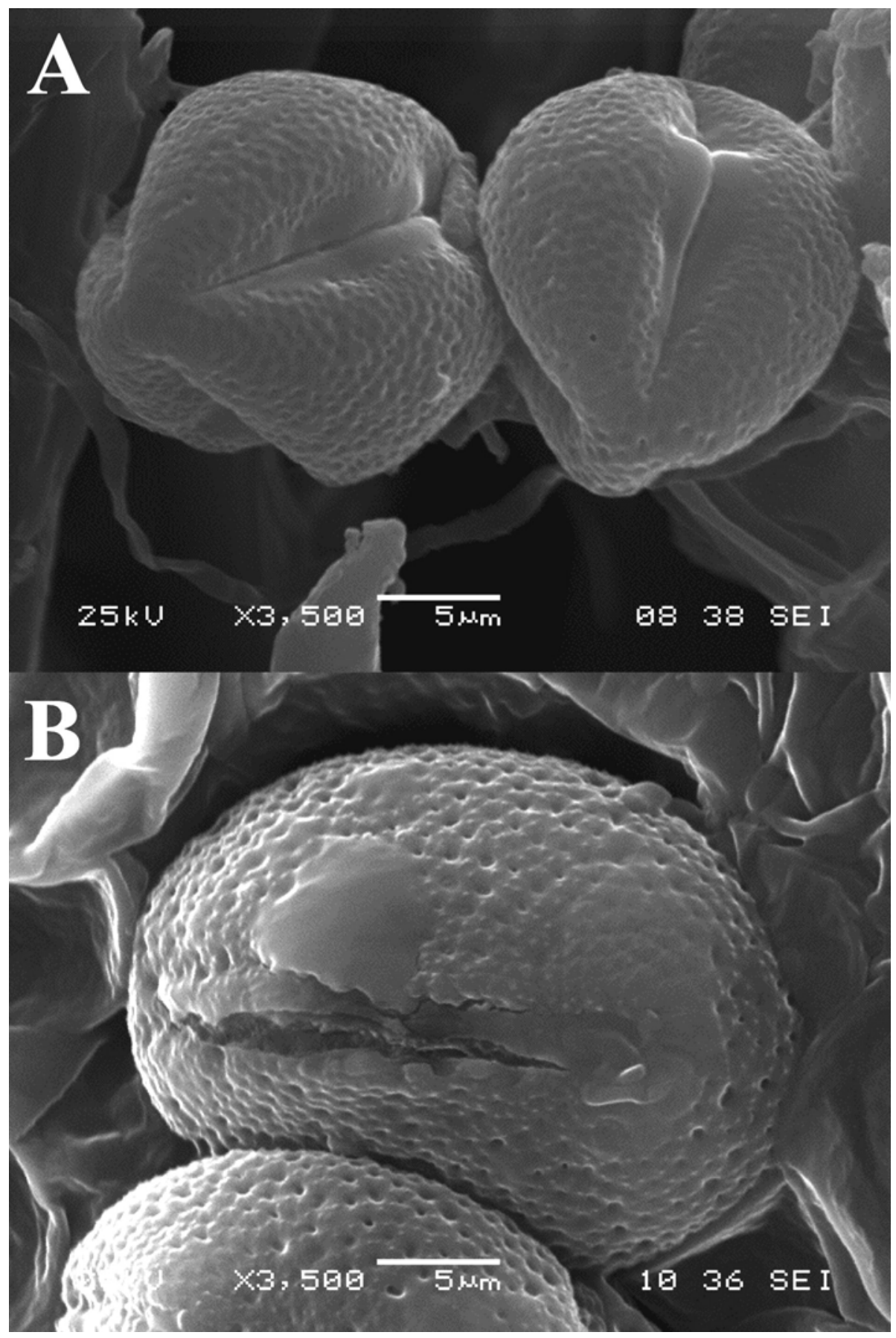


FIG. 2. Strict consensus tree obtained after the maximum parsimony phylogenetic analyses of the subset from the Acalyphoideae using $r b c L$ and $t r n L-F$ nucleotide sequences. On the left is the $r b c L$, on the right is the trnL-F. Bootstrap values are shown above the nodes.

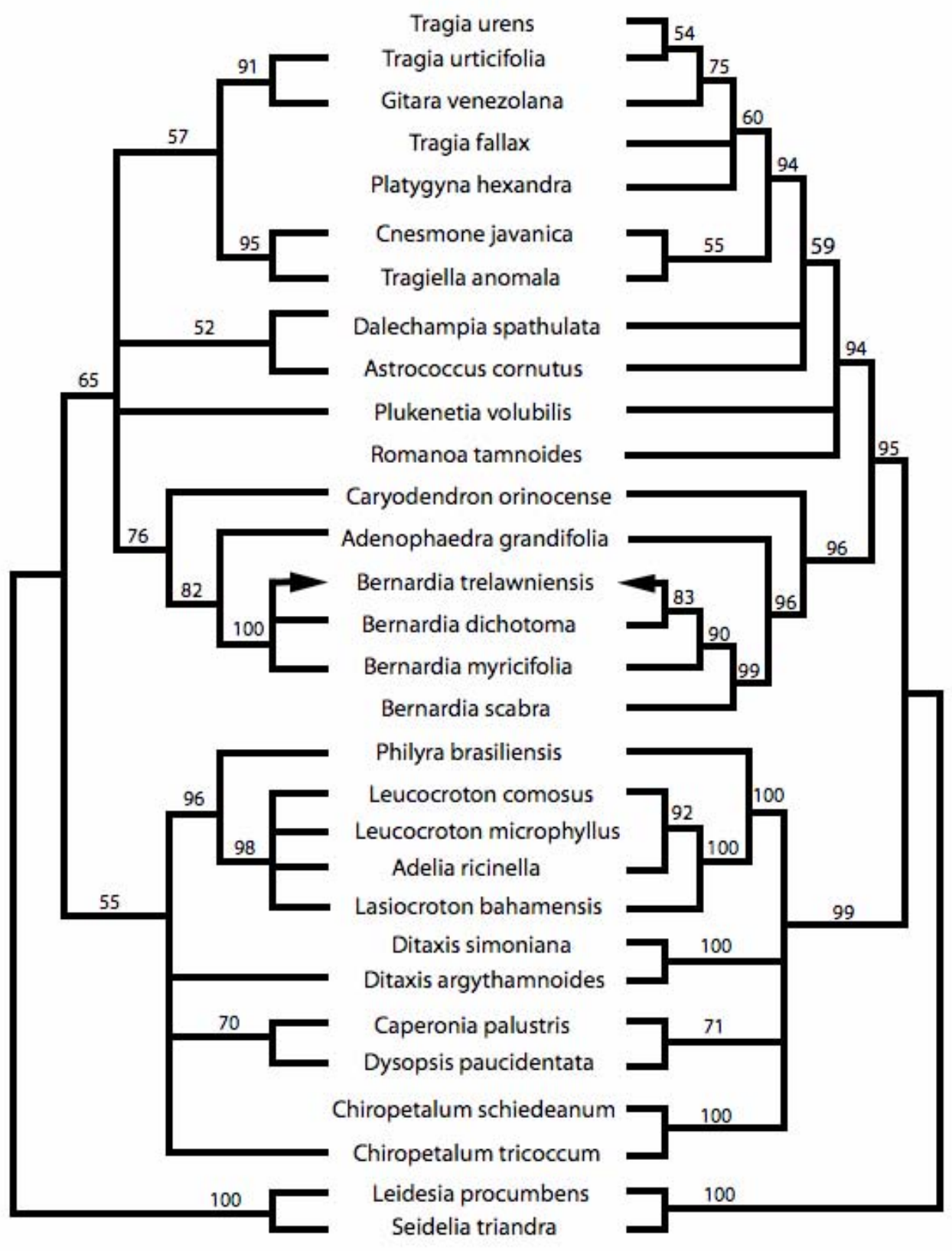


FIG. 3. Strict consensus tree obtained after the maximum parsimony phylogenetic analysis of the subset from the Acalyphoideae using combined $r b c L$ and $t r n L-F$ nucleotide sequences. Bootstrap values are shown above the nodes.

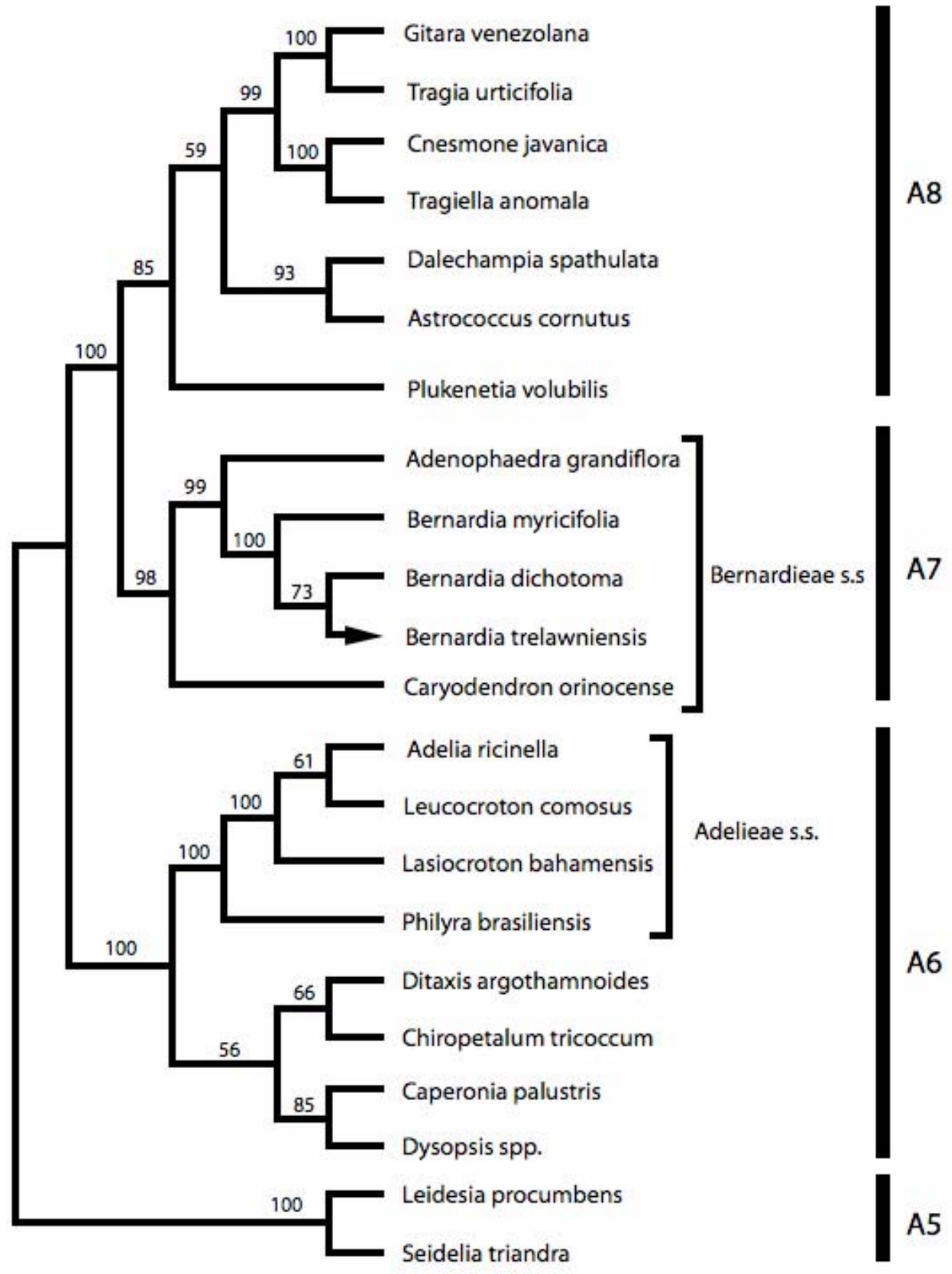




\section{CHAPTER II}

The generic delimitations of the Antillean members of tribe Adelieae (Euphorbiaceae) and the description of the Hispaniolan endemic genus Garciadelia

Brett Jestrow $^{1,2}$, Francisco Jiménez ${ }^{3} \&$ Javier Francisco-Ortega ${ }^{1,2}$

1 Department of Biological Sciences, Florida International University, Miami, Florida 33199, U.S.A.

2 Center for Tropical Plant Conservation, Fairchild Tropical Botanical Garden, Coral Gables, Miami, Florida 33156, U.S.A

3 Jardín Botánico Nacional, Apartado Postal 21-9, Santo Domingo, Dominican Republic

Author for correspondence: Brett Jestrow, bjest001@fiu.edu 


\begin{abstract}
The Caribbean Island Biodiversity Hotspot is the largest insular system of the New World and a priority for biodiversity conservation worldwide. The tribe Adeliae (Euphorbiaceae) has over 35 species endemic to this hotspot, representing a prime example of speciation in the West Indies, involving taxa from Cuba, Hispaniola, Jamaica, and the Bahamas. These species form a monophyletic group and traditionally have been accommodated in two endemic genera: Lasiocroton and Leucocroton. A study was conducted on: (1) scanning electron microscopy of pollen, (2) macromorphology, and (3) molecular phylogenies, to reveal generic relationships within this group. Phylogenies were based on parsimony and Bayesian analyses of nucleotide sequences of the ITS regions of the nuclear ribosomal DNA and the non-coding chloroplast DNA spacers $p s b M-t r n D$ and $y c f 6$ pcbM. Three major monophyletic assemblages were revealed; one of them is restricted to Hispaniola and is accommodated in a new genus, Garciadelia, with four species. This genus is sister to a clade comprising two monophyletic groups. The first of these two groups includes all species of Leucocroton and is restricted to serpentine soils of Cuba. The second group includes the species of Lasiocroton, with species occurring in Cuba, Hispaniola, Jamaica, and the Bahamas. Morphological, biogeographical, and ecological data provided additional support for each of these three monophyletic assemblages. Two new combinations (i.e., Lasiocroton microphyllus from Cuba and Garciadelia leprosa from Hispaniola) are made. Four new species are described (Lasiocroton gutierrezii from Cuba, and Garciadelia abbottii, G. castilloae, and G. mejiae from Hispaniola).
\end{abstract}




\section{INTRODUCTION}

The Caribbean Islands Biodiversity Hotspot, as defined by Smith \& al. (2004), includes the Greater and Lesser Antilles, as well as the Bahamas and most of the islands off the Venezuelan coast. This insular system includes over 8,000 endemic plant species (Santiago-Valentín \& Olmstead, 2004), and is ranked among the eight most important biodiversity hotspots based on endemicity, massive habitat loss, and vulnerability to extinction (Myers \& al., 2000). The threatened nature of such a high-diversity area has raised both conservation and scientific concerns in the region (Maunder \& al., 2008). Of particular interest to this research are Lasiocroton Griseb. and Leucocroton Griseb. (Euphorbiaceae); two of the approximately 184 endemic seed plant genera restricted to the hotspot (Francisco-

Ortega \& al., 2007, 2008; Acevedo \& Strong, 2008; Schaeffer \& al., 2008). Wallenia Sw. (40 spp.) (Myrsinaceae), Calycogonium DC. (36 spp.) (Melastomataceae), and Dendropemon (Blume) Rchb. (36 spp.) (Loranthaceae) are the only endemic genera that have a larger number of species than the focal genera of this study (reviewed by Francisco-Ortega \& al., 2007, 2008).

Lasiocroton has long been considered closely allied to Leucocroton (Grisebach, 1861; Pax \& Hoffman, 1914; Webster, 1994), and a sister relationship of these two genera is strongly supported by recent molecular phylogenetic studies (Wurdack \& al., 2005; De-Nova \& Sosa, 2007). Lasiocroton and Leucocroton together constitute one of the most important examples of species radiation for the Caribbean seed-plant genera. Only three additional monophyletic assemblages of multiple endemic genera, which include more than 20 species, are known. The first one is in the Rubiacae: Isidorea DC. (17 spp.), a genus endemic to Cuba 
and Hispaniola, and the Jamaican endemic Portlandia P. Browne (7 spp.) are sister taxa (Motley \& al., 2005). The second case is found in the Orchidaceae as the endemic genera Broughtonia R. Br. (6 spp.), Psychilis Raf. (15 spp.), Quisqueya Dod (4 spp.), and Tetramicra Lindl. (13 spp.) form a monophyletic group (Van Den Berg \& al., 2000, 2005). Finally, the tribe Senecioneae (Asteraceae) has possibly the largest Caribbean endemic clade including ten genera: Antillianthus B. Nord. (17 spp.), Elekmania B. Nord. (10 spp.), Ekmaniopappus Borhidi (2 spp.), Herodotia Urb. \& Ekman (1 sp.), Leonis B. Nord. (1 sp.), Lundinia B. Nord. (1 sp.), Mattfeldia Urb. (1 sp.), Nesampelos B. Nord. (3 spp.), Oldfeltia B. Nord. \& Lundin (1 sp.), and Zemisia B. Nord. (1 sp.) (Pelser \& al., 2007). Further endemic genera not included in the Pelser \& al. (2007) phylogenetic study, but which are closely allied members of the Senecioneae include: Herreranthus B. Nord. (1 sp.), Ignurbia B. Nord. (1 sp.), Odontocline B. Nord. (6 spp.), and Shafera Greenm. (1 sp.) (Nordenstam, 2006). Lasiocroton and Leucocroton belong to tribe Adelieae (subfamily Acalyphoideae).

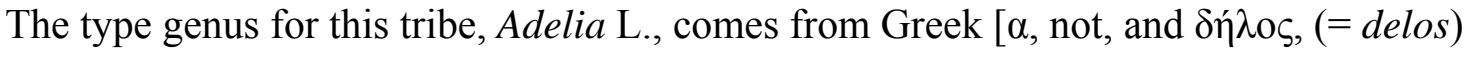
visible] a name chosen by Linnaeus (1759) presumably for the difficulties in interpreting this taxon. The members of the Adelieae have undergone considerable taxonomic changes, particularly during the last five years. While the tribe formerly included five genera (Webster, 1975, 1994; Radcliffe-Smith, 2001), molecular phylogenies show that two of them, Crotonogynopsis Pax and Enriquebeltrania Rzed., are no longer considered to be part of this taxon (Wurdack \& al., 2005; De-Nova \& al., 2006). Currently Adelia, Lasiocroton, and Leucocroton form the central core of the Adelieae (Jestrow \& al., 2008), and recent DNA phylogenetic studies also support the monospecific genus Philyra Klotzsch as belonging to the tribe (Wurdack \& al., 2005). Therefore in my study the Adelieae include Adelia, 
Lasiocroton, Leucocroton, and Philyra as suggested by Jestrow \& al. (2008). Adelia and Philyra are found in the continent from Mexico to Brazil with a single species, A. ricinella L., reaching the Caribbean Islands.

The first infrageneric molecular phylogeny for the tribe was constructed for Adelia (De-Nova \& al., 2007) with representative taxa from Lasiocroton and Leucocroton. That phylogenetic study built on the previous $r b c L$ and trnl-F phylogeny of Wurdack \& al. (2005) by adding nucleotide sequence data from the internal transcribed spacers (ITS1 and ITS2) of the nuclear ribosomal DNA and morphological data.

Available taxonomic keys for Lasiocroton and Leucocroton are difficult to follow and do not provide good discriminatory characters among the genera and their species (e.g., Borhidi, 1991; Webster, 1994; Radcliffe-Smith, 2001). For example, the keys of Webster (1994) and Radcliffe-Smith (2001) defined Leucocroton as having 4-colpate pollen; however, my micro-morphological observations show that this genus has 3-colpate pollen.

Species of Leucocroton have been the subject of ecophysiological studies, because of their extraordinary ability to hyperaccumulate nickel (Berazaín \& al., 2007). All 26 species of this genus found on the serpentine soils of Cuba are known to sequester nickel (Reeves \& al., 1996). Indeed, Leucocroton has more nickel hyperaccumulating species than any other genus endemic to the West Indies (Reeves \& al., 1996, 1999).

The last significant taxonomic revision of Leucocroton was completed by Borhidi (1991), who listed 28 species comprising three sections (i.e., Adeliocroton Borhidi, Lasiocrotonopsis Borhidi, and Leucocroton). In addition, seven new species of the genus were described in his study. Leucocroton section Adeliocroton included only two species, and are the only ones not found on serpentine soils. Borhidi (1991) segregated this section 
based on free stamens, as opposed to the connate stamens of the remaining two sections of the genus. Of the two non-serpentine species, L. microphyllus is confined to coastal limestone scrub of Cuba. The second one, L. leprosus (Willd.) Pax \& K. Hoffm. (transferred to Garciadelia in the present study, see below), is the only member of the genus found on the island of Hispaniola. The other two sections, Leucocroton (19 spp.) and Lasiocrotonopsis (7 spp.), comprise the majority of the taxa and were segregated from each other by Borhidi (1991) according to leaf venation and, marginally, by stamen number.

In this study I used molecular data from the nuclear and chloroplast genomes to investigate phylogenetic relationships between the West Indian genera of the Adelieae. The resulting phylogeny was interpreted in the light of micro- and macromorphological data either specifically obtained for my research or reported in previous studies (i.e., Jestrow \& al., 2008 and Takahashi \& al., 2000). Section Adeliocroton is a main focus of this research, both in the proposing of the new genus Garciadelia (including Leucocroton leprosus) and in the new combination Lasiocroton microphyllus (formerly in Leucocroton). The ultimate goal of this study was to analyze the monophyly of the genera and what, if any, consistent generic groups exist within this group. In order to avoid confusion, the new taxonomic nomenclature (see below) will be followed throughout this work, with what I have named the "Leucocroton alliance" consisting of three genera: Garciadelia, Lasiocroton, and Leucocroton. All of the species of Garciadelia and Lasiocroton grow on limestone soils and form two monophyletic groups; likewise all Leucocroton taxa are endemic to serpentine areas of Cuba and form a distinct lineage (see below). 


\section{MATERIALS AND METHODS}

Taxon sampling. -- A total of 19 taxa were sampled from 17 previously recognized species. The most distant outgroup was Bernardia dichotoma from the tribe Bernardieae of subfamily Acalyphoideae (Jestrow \& al., 2008). The outgroup also included Caperonia palustris from the tribe Chrozophoreae. A previous phylogenetic study showed these two genera to be closely related to the Adelieae (Wurdack \& al., 2005). The ingroup consisted of representatives from both the Leucocroton alliance and the rest of the tribe, including the monospecific genus Philyra and three species of Adelia representing the main lineages of this genus. My study included the type of Lasiocroton, L. macrophyllus (Webster, 1994;

Radcliffe-Smith, 2001), as well as three species from each of the main lineages of this genus (Jestrow \& al., unpublished): L. microphyllus [moved from Leucocroton section Adeliocroton in this study (see below)], the widely-distributed L. bahamensis, and the Jamaican endemic, L. harrisii. Six species from Leucocroton were selected as representatives of the five main clades of this genus as identified in a separate phylogenetic study (Jestrow \& al., unpublished), including the type of the genus, L. wrightii (Webster, 1994; RadcliffeSmith, 2001). Four of them belong to the section Leucocroton (i.e., L. comosus, $L$. linearifolius, L. pachyphyllus, and $L$. wrightii) and two to section Lasiocrotonopsis (i.e., $L$. moncadae and L. virens) as described by Borhidi (1991). As for the new genus Garciadelia (including the former Leucocroton leprosus), the three new species described in this study (see below) were used (i.e., G. abbottii, G. castilloae, and G. mejiae). Unfortunately, I did not include the Haitian endemic G. leprosa because I was unable to obtain samples of this extremely rare species. 
DNA extraction, amplification, and sequencing. -- DNA of plant samples was extracted from silica-dried material using a DNeasy Plant Mini Kit (Qiagen, Valencia, California). PuReTaq Ready-To-Go PCR Beads (GE Healthcare Life Sciences, Piscataway, New Jersey) were used for the PCR amplification reaction mix. For all regions, the cycle program used is as follows: (1) $80^{\circ} \mathrm{C}$ for $5 \mathrm{~min}$; (2) $94^{\circ} \mathrm{C}$ for $1 \mathrm{~min}$; (3) $50^{\circ} \mathrm{C}$ for $1 \mathrm{~min}$; (4) $72^{\circ} \mathrm{C}$ for $2 \mathrm{~min} ; 35$ cycles from step (2); and (5) $72^{\circ} \mathrm{C}$ for $5 \mathrm{~min}$. Chloroplast noncoding regions, $p s b M-t r n D$ and $y c f 6-p c b M$ were amplified with primers previously published by Shaw \& al. (2005). The ITS1, 5.8s, and ITS2 were amplified as one region using primers ITS 5 (Downie \& Katz-Downie, 1996) and ITS 4 (White \& al., 1990). For members of Garciadelia, the total ITS regions were cloned prior to sequencing. Cloning was needed because of the poor quality of sequences obtained after direct sequencing for the species of this genus (see Results below). There was no need to clone the sequences obtained for the rest of the taxa because direct sequencing yielded clean products that were easily read and interpreted. I used TOPO TACloning (Invitrogen, Carlsbad, California), following the manufacturer's guidelines. Cycle sequencing was performed in both directions with the PRISM BigDye v.3.1 Terminator Cycle Sequencing Kit (Applied Biosystems, Foster City, California) following the manufacturers instructions. The primers used for PCR amplification were also utilized for the cycle sequencing reactions. Nucleotide sequences were visualized on a PRISM 377 Automated DNA Sequencer (Applied Biosystems, Foster City, California) at the Florida International University (FIU) DNA Core Facility. All sequences were submitted to GenBank (see Appendix).

Phylogenetic analyses. -- All sequences were assembled using the automated alignment option of Sequencher 3.1.1 (Gene Codes Corporation, Ann Arbor, Michigan) and 
visually adjusted using MacClade 4.06 (Madison \& Madison, 2000). A single region in the $y c f 6-p c b M$ alignment was removed because of a large " $T$ " repeat within the ingroup (20-40 $\mathrm{bp})$, this repeat also coincided with a large (254 bp) insertion in Bernardia dichotoma and was also eliminated from the alignment. All regions were gap-coded using the Simple Indel Coding method (Simmons \& Ochoterena, 2000). For the ITS regions, only the ingroup was scored for gaps because of the alignment ambiguities because of the level of saturation with both B. dichotoma and Caperonia palustris. These gap characters were scored as missing data for the outgroup.

The parsimony analyses for the ITS matrix was based on a heuristic search with 10,000 random replicates saving no more than 100 trees for each step with the TBR and Multrees options. Clade support was assessed with bootstrap analysis but searches were conducted using a 10,000 replicate heuristic approach with starting trees from random addition. For the chloroplast and combined data sets, parsimony analysis was based on a Branch and Bound search using PAUP* 4.0b10 (Swofford, 2003). Statistical support for each clade was evaluated through bootstrap analysis (Felsenstein, 1985) with Branch and Bound searches using 10,000 replicates in PAUP*. Consistency index (CI; excluding uninformative characters), retention index (RI), and rescaled consistency index (RC) were calculated (Kluge \& Farris, 1969; Farris, 1989). Incongruence Length Difference (ILD) tests were run between the three data sets (ITS, $p s b M-t r n D$, and $y c f 6-p c b M$ ). Branch lengths were assigned by the Deltran algorithm. For the combined analyses (see Results below) I chose one ITS clone per Garciadelia species based on the minimum number of autapomorphic characters. This selection allowed us to avoid any false inflation of the branch lengths. Therefore the 
following ITS clones were included in this combined analysis; G. abbottii, GU000002; G. castilloae, GU000008; and G. mejiae, GU000012.

Bayesian methods were also used for phylogenetic inferences. For this analysis, I did not include gap-coding because of uncertainties regarding molecular evolution modeling. Each region (ITS1, 5.8s, ITS2, psbM-trnD, ycf6-pcbM) were run separately through Modeltest v.3.06 (Posada \& Crandall, 1998) to identify the models and parameters. Models were chosen based on the Akaike Information Criterion as explained in Posada and Crandall (1998). I used the following models for the Bayesian analyses: ITS 1, GTR $+\mathrm{I}+\mathrm{G} ; 5.8 \mathrm{~s}$, TRNef+I; ITS2, TRN+G; psbM-trnD, K81uf+I; and ycf6-pcbM, TVM+G. Bayesian inferences were conducted using MrBayes 3.1.2 (Huelsenbeck \& Ronquist, 2001) with two MCMC runs of four linked chains for 1,000,000 generations, sampling every 100 generations. The four chains included one cold, and the other three with incremental heating as per the default of MrBayes. Of the 10,001 trees produced per MCMC run, the first $25 \%$ of them were removed as burnin, resulting in a total of 15,000 trees. The burnin of $25 \%$ was determined to be adequate from the likelihood values, as the values leveled off by 100,000 generations for the datasets. All Bayesian analyses produced split frequencies of less than 0.015 , showing convergence between the paired runs. I then used PAUP* to compute the majority consensus tree for the total data to give the posterior probabilities. For the Bayesian analysis of the total combined data set, the estimated rates of changes per character were saved for each branch in order to compare the relative branch lengths.

SEM studies. -- Pollen from the species of the Leucocroton alliance included in the phylogenetic analysis were removed from herbarium specimens collected from the wild or from the living collections of Fairchild Tropical Botanic Garden (see Appendix). They were 
studied with Scanning Electron Microscopy (SEM) at the Florida Center for Analytical Electron Microscopy (FCAEM) of FIU using the JSM 5900LV (JEOL, Tokyo, Japan) instrument. Untreated samples were coated with gold-palladium using a SPI-Module Sputter Coater (SPI Supplies, West Chester, Pennsylvania) at $367 \AA$ for four minutes. I examined an additional species for pollen, Lasiocroton fawcetti Urb., that was not included in the phylogenetic analysis. I also made comparisons with pollen SEM images previously published by Jestrow \& al. (2008) and Takahashi \& al. (2000).

\section{RESULTS}

ITS analyses. -- The aligned ITS data matrix was 764 nucleotide positions in length and included 175 parsimony informative (PI) nucleotide positions along with five PI coded gaps (Table 2). Of these, approximately half ( 89 nucleotides and three coded gaps) were PI within the Leucocroton alliance. The strict consensus tree of the 14 most parsimonious trees shows Adelia cinerea to be sister to the Leucocroton alliance, although with low bootstrap support (Fig. 4). Within the Leucocroton alliance, Garciadelia was found to be sister to a clade formed by Lasiocroton and Leucocroton, but with low bootstrap support. However, the monophyly of the three genera of the Leucocroton alliance was strongly supported with bootstrap values ranking between 100\% (Garciadelia and Leucocroton) and 99\% (Lasiocroton). Interestingly, the two species of Leucocroton section Lasiocrotonopsis (i.e., L. moncadae and L. virens) were not found to be sister taxa.

Putative ITS sequences of Garciadelia abbottii, G. castilloae, and G. mejiae, were cloned because it was difficult to produce clean sequences by direct sequencing. Through 
GenBank searches I blasted the cloned sequences of these three species and found that a few of them matched (up to $88 \%$ of the query coverage) ITS accessions of endophytic Ascomycetes. This explained my difficulties to obtain readable ITS sequences of this genus from direct PCR products. The fungal clones from the Garciadelia species were quite similar to each other, and were easy to align manually. These initial GenBank searches also showed that the majority of the cloned sequences matched ITS accessions of the Leucocroton alliance. I was able to recover five ITS clone sequences for each of these three Garciadelia species. The fives clones for a given species differed from each other by no more than two mutations (Fig. 4). The cladistic analysis showed the multiple ITS clones of G. abbottii and G. castilloae forming two distinct monophyletic groups with bootstrap supports of $61 \%$ and $93 \%$ respectively. A single nucleotide change supported the clade of clones of G. abbottii. Three mutations were synapomorphies for the ITS clone clade of G. castilloae. However, no synapomorphies supported the clones of G. mejiae as a distinct clade (Fig. 3).

The Bayesian analysis produced a tree without any conflict to the parsimony strict consensus topology. However, this analysis did not find support for a sister relationship between Adelia cinerea and the Leucocroton alliance, but a polytomy with the species of Adelia (Fig. 3). Bayesian posterior probabilities for all three genera were $100 \%$.

Chloroplast analyses. -- The aligned $p s b M$-trnD and $y c f 6-p s b M$ data matrices were 1065 and 1222 nucleotide positions in length, respectively (Table 2). The data set of psbMtrnD included 38 PI nucleotide positions along with 15 PI coded gaps, and the $y c f 6-p s b M$ data matrix had 43 PI nucleotide positions and 16 PI coded gaps. Within the Leucocroton alliance, the $p s b M$-trnD data set yielded eight PI nucleotide positions with ten PI coded gaps, while the $y c f 6-p s b M$ alignment had 16 PI nucleotide positions with seven PI coded gaps. One 
of the six most parsimonious trees of $p s b M-\operatorname{trn} D$ conflicted with the strict consensus at a single node, which collapsed in the bootstrap analysis (Fig. 5). The ycf6-psbM search produced a single most parsimonious tree.

In contrast to the results produced by the parsimony analyses of the ITS and $y c f 6$ psbM data, the psbM-trnD phylogeny found a clade formed by Adelia ricinella and A. vaseyi as sister to the Leucocroton alliance; however, this relationship was poorly supported with a bootstrap value of $71 \%$. The $y c f 6-p s b M$ tree conflicted with both the ITS and $p s b M-t r n D$ topologies by nesting Philyra within the Adelia clade, this relationship was strongly supported with a bootstrap value of $100 \%$. Within the Leucocroton alliance, both the psbMtrnD and the $y c f 6-p s b M$ trees found Garciadelia to be sister to the Lasiocroton and Leucocroton clade with high bootstrap support greater than $83 \%$ and $92 \%$.

Bayesian and parsimony analyses conflicted only at a single node of the psbM-trnD tree (represented by the "\#” in Fig. 5). The Bayesian topology placed Philyra between Caperonia and Bernardia, although with a low Bayesian posterior probability of $69 \%$. The Bayesian analysis of the $y c f 6-p s b M$ did not find support for a sister relationship between Adelia cinerea and the Leucocroton alliance, but a polytomy with the species of Adelia (Fig. 5).

Combined analyses. -- The ILD tests showed conflicts between the $y c f 6$ and ITS $(\mathrm{P}=0.01)$ and between the trnD and $y c f 6(\mathrm{P}=0.01)$ data sets. The ITS-trnD ILD test had less conflict $(\mathrm{P}=0.07)$. I found Philyra brasiliensis to be the prime culprit in creating the incongruence, and when I removed this taxon from the analyses, I resolved the conflicts [i.e., ITS-trnD (P=0.38), ITS-ycf6 ( $\mathrm{P}=0.11)$, and trnD-ycf6 $(\mathrm{P}=0.52)]$. When Adelia cinerea was not included, then I found an even higher rate of congruence, especially between the two 
chloroplast regions [trnD-ycf6 $(\mathrm{P}=1.00)]$. Clearly these two species constituted the source for incongruence, but whether included or not in the phylogenetic analyses, they did not affect the topology of the Leucocroton alliance. I decided to keep both A. cinerea and $P$. brasiliensis in my combined analyses, but remain aware of the difficulty in ascertaining their proper placement in the tribe. Looking at the combined phylogeny, Lasiocroton, Leucocroton, and Garciadelia form highly supported monophyletic clades, according to both Bayesian and parsimony approaches.

My combined analysis also showed a sister relationship of Garciadelia to the rest of the alliance (Fig. 6). The combined parsimony analysis found Adelia cinerea to be sister to the Leucocroton alliance with a bootstrap support of $90 \%$, however the Bayesian analysis did not resolve this relationship. The placement of $A$. cinerea is problematic as already indicated by De-Nova \& al. (2007), and I do not feel justified in granting this species with generic status without complete agreement between both phylogenetic analyses.

Pollen SEM analyses. -- All pollen of the Leucocroton alliance had three colpi, opercula, and a perforated testa, in contrast with earlier reports by Webster (1994) that indicated that some of these taxa had pollen with four colpi. The palynological study of Takahashi \& al. (2000) recognized these three traits as synapomorphies of the Leucocroton alliance; however, these authors had a limited taxonomic sampling, and did not report any pollen autapomorphies for Garciadelia as I found in this study.

Garciadelia pollen has a conspicuously reticulate-perforated incomplete testa (Fig. 7A, 7B, 7C). In contrast, Leucocroton pollen has considerably smaller pores in their testa, with L. virens (Fig. 7H) having the largest pores I have observed in the genus, including those images published by Takahashi \& al. (2000). The Jamaican species of Lasiocroton had 
a nearly complete testa, while L. bahamensis and L. microphyllus had considerably larger pores. Polar-equatorial length ratio (P/E) patterns were concordant with the resulting phylogeny. Low $\mathrm{P} / \mathrm{E}$ ratios are common in Leucocroton, as shown in L. linearifolius and $L$. pachyphyllus with pollen grains wide and flat in shape. In contrast, the pollen grains of Garciadelia and Lasiocroton are generally elongate, with high P/E ratios, approaching a spherical shape as shown in L. microphyllus. Likewise, the pollen opercula of all of the Leucocroton species are wider and more pronounced than the other genera, with the single exception of Lasiocroton microphyllus; a species that exhibited a unique mosaic of character traits also found in the other two genera. The pollen of Adelia cinerea (shown by Cervantes \& al., 2003) has a similar operculum and shape to Garciadelia, though the perforations are not as dramatic.

Garciadelia as a distinct monophyletic genus. -- Criteria to define new genera have been a central focus in plant systematic and taxonomy, even in specific reference to the Euphorbiaceae (Humphreys \& Linder, 2009; Judd \& al., 2008; Berry \& al., 2005). One only needs to look at the abundance of published, only to be abandoned generic names in the family, to recognize it.

After my research, I was left with two possibilities, either describing a large inclusive genus or dividing the group into three genera that correspond with the major clades identified in my study. By going the route of the large genus, I will not recognize the major ecological, physiological, biogeographical, and morphological differences behind the three major monophyletic groups found in my study.

With three genera, the taxonomy reflects clearly the evolutionary history of this group, which is one of the central tenets of modern taxonomy (Judd \& al., 2008). My study 
shows that Leucocroton includes 26 species, all of which are endemic to serpentine areas of Cuba and have the ability to hyperaccumulate nickel. No other endemic plant genus from the Caribbean Islands displays this extraordinary radiation along the naturally fragmented landscape of serpentine soils found across Cuba. Leucocroton represents the paradigm of speciation on this unique environment of the neotropics. These physiological traits are not found in any member of Garciadelia or Lasiocroton. Importantly, the three genera recognized in my study are morphologically distinct (see taxonomic treatment below). I also found that Garciadelia has pollen with large perforations as an autapomorphic trait. In addition, this genus is the earliest branch of the alliance and its pollen has similar operculum and shape to Adelia cinerea. Interestingly this Mexican species is supported as sister to the Leucrocroton alliance in the parsimony analyses of the ITS, $y c f 6-p c b M$, and combined data sets.

Accepting these three genera elucidates the biogeographic knowledge present in the phylogeny, namely that Cuban and Hispaniolan species each form a separate clade, with all these groups following the rules of monophyly. Finally, from a conservation viewpoint, Garciadelia has some of the most endangered species of the dry lowland shrub of the biodiversity hotspot (see below). From this perspective, to dissolve this genus into another would be to eliminate any ability to recognize quickly the evolutionary and conservation significance of the genus.

For a single all-encompassing genus, Lasiocroton, would take taxonomic precedence, as it is the earliest published genus of the clade. Therefore, all 28 species formerly included in Leucocroton would have to be described under the new combinations. This change would take significant amount of effort, and would ultimately only serve to remove information 
from the evolutionary history as explained above. The situation is made much simpler with the naming of the new genus Garciadelia. I needed to move only one species, Leucocroton microphyllus, to Lasiocroton, while the species Leucocroton leprosus is transferred to G. leprosa. I publish three new species in Garciadelia, but these are new descriptions and hold no sway as to how I divide the genera.

\section{TAXONOMIC TREATMENT}

\section{Key to the genera of the Leucocroton alliance}

1. Stamens mostly connate; restricted to serpentine soils on Cuba; nickel-

hyperaccumulators

Leucocroton

1. Stamens free; restricted to limestone soils; not nickel-hyperaccumulators 2

2. Leaf lamina width/length ratio greater than 0.5 or leaves less than $25 \mathrm{~mm}$ in length, pistillate disk thick. Lasiocroton

2. Leaf lamina width/length ratio less than 0.5 and leaves more than $25 \mathrm{~mm}$ in length, pistillate disk absent. Garciadelia

Lasiocroton microphyllus (A. Rich.) Jestrow, comb. nov. -- Adelia microphylla A. Rich. in Ramón de la Sagra: Hist. Fis. Cuba 11: 209. $1850 \equiv$ Bernardia microphylla (A. Rich.) Müll. Arg. in Linnaea 34: 172. 1865 三 Leucocroton microphyllus (A. Rich.) Pax \& K. Hoffm. in Engler: Pflanzenr. IV.147.VII. 64. 1914 -- Type: Cuba. Legit Ramón de la 
Sagra, P00635080. Holotype (P!, photo of herbarium specimen examined), isotypes

(G-DC!, photos of two herbarium specimens examined).

= Bernardia lycioides Müll. Arg. ex Pax \& K. Hoffm. in Engler: Pflanzenr. IV. 147. VII. 64.

1914, nom. nud.

Shrubs 0.5--2 m, dioecious, indumentum of rugose-peltafid trichomes. Stems stout and heavily branched, 1.5--4 mm thick, branches typically terminating in stout stem-spines. Leaves alternate, simple, oblong to obovate, 5--25 mm long, 2--5 mm wide, mucronate with a rounded apex, bluish-green, no vein impression, exstipulate, no glands; petioles poorly defined to $1 \mathrm{~mm}$ long. Staminate inflorescence spicate, 5--10 flowered, 10--65 mm long; staminate flowers with a single whorl of 5 sepals, 10 stamens. Pistillate inflorescence racemes, 1--3 flowered, 10--20 mm long; pistillate flowers with 5 sepals, pedicel 3--6 mm, disk thick, style 3--branched and compactly laciniate. Fruit a trilobed schizocarp, 2--3 mm diam.

Distribution, habitat, and collection history. -- I have examined a photo of a specimen of this species collected by Sagra in the herbarium of A. Richard located at P. The protologue refers to: "Crescit circa Havanam, in locis saxosis (Ramon de la Sagra) et in Vuelta de abajo, (J.-M. Valenzuela)" (Richard, 1850). Borhidi (1991) interprets "Sagra 58 (P)" as the holotype for this name, however Sagra 58 is located in G. Therefore I am not certain if Borhidi (1991) was referring to material found in P or in G. The herbarium of P has a single Sagra collection, without any collection number. This specimen was labeled as "HOLOTYPUS" by F. Zimmermann in 1991. I concord with Zimmermann's typification, as the specimen belonged to the herbarium of Richard, was collected by Sagra, and it follows the original description by Richard (1850). Therefore I consider this material to be the 
holotype of Adelia microphylla A. Rich. Pax \& Hoffmann (1914) listed Bernardia lycioidies Müll. Arg. as a synonym of Leucocroton microphyllus, but this name was never published, so it is a nomen nudum.

Lasiocroton microphyllus is endemic to Cuba and is restricted to coastal scrub on limestone soils. After Lasiocroton bahamensis, which is more abundant and has a broader distribution area, it is the second most common and widely distributed species of the Leucocroton alliance. Most collections are from three distinct areas of the island (i.e., the northern coast of Habana province from El Mariel to Cojimar, the southern coast of Cienfuegos, and the coastlines of Santiago-Guantánamo-Holguín to the northern coasts and islands of Las Tunas-Camagüey-Ciego de Avila provinces). The coastal limestone scrub is also known as "manigua costera" and this ecosystem directly follows the distribution of $L$. microphyllus, with the single exception of the extreme southwestern coastal area of Pinar del Río, where L. microphyllus is unknown (Castro, 1978). Lasiocroton microphyllus is widespread, but is nowhere common or dominant. Many of the previous collections, particularly those in and near the City of Havana and the Havana province, have not been collected in the last fifty years. This species warrants the IUCN (2007) status of Near Threatened because of its apparent rarity.

Lasiocroton gutierrezii Jestrow, sp. nov. -- Type: Shady place, limestone rocks, Sierra de Grillo, Madruga. No. 5289. Feb. 24,1956. Col. Bro. Alain, HAC17403 -- Holotype (HAC!), isotype (GH!).

Lasiocrotone microphyllo affinis sed caulibus gracilisbus et sine spinis. 
Shrubs to $1.5 \mathrm{~m}$ tall, dioecious, indumentum of rugose-peltafid trichomes. Stems narrow and trailing, 0.5--1.5 mm thick, lacking stem-spines. Leaves alternate, simple, narrowly obovate, 10--30 mm long, 2--5 mm wide, mucronate with a rounded apex, bluish-green, no vein impression, exstipulate, no glands; petioles poorly defined to $1 \mathrm{~mm}$ long,. Staminate inflorescence spike, 5--10 flowered, 10--25 mm long; staminate flowers with 5 sepals. Pistillate inflorescence panicle, 3--10 flowered; pistillate flowers with 5 sepals, disk thick, style 3--branched and compactly laciniate. Fruit a trilobed schizocarp. Figure 10.

Distribution, habitat, and collection history. -- Among the herbarium specimens that I initially assigned to Lasiocroton microphyllus, all but one was from the dry, coastal, scrub areas of Cuba. This single exception (Alain 5289) is from an inland locality of the Grillo Range, located in the center of the island, midway between north and south coasts of Havana province. The specimen immediately stood out because of its long, narrow, trailing stems, and lack of stem spines. While examining photographs of specimens from HAC, an additional specimen had the same morphological traits and was also collected from an inland site outside the "manigua costera" (see above). This second locality was from the Escaleras de Jaruco, which constitutes the northwestern edge of the limestone highlands of the provinces of Havana and Matanzas, while the former locality occurs near the southeastern edge of these hills (Fig. 9). This additional collection was of pistillate material and showed inflorescences with 3--10 flowers, unlike L. microphyllus, which has 1--3 flowers.

Lasiocroton gutierrezii, now known from only two collections, is therefore justified by both morphology and distribution. The two localities are typical of the semideciduos forests of central Cuba as shown by Castro (1978). I honor Dr. Jorge Gutiérrez of the Jardín Botánico Nacional, Universidad de Habana, with the eponym, for his life long dedication to 
the flora of Cuba and his particular contributions to the taxonomy of the Euphorbiaceae. I consider this species as Endangered according to the IUCN criteria [B1ab(i)].

Garciadelia Jestrow \& Jiménez Rodr., gen. nov. -- Type: Croton leprosus Willd. Sp. Pl., ed. 4, 4 (1): 553. 1805.

Arbuscula et frutices, dioecius, indumentum stellatum. Folia alternata, simplex, cordata, penninervis, stellatopilosa, estipulata, eglandulata. Inflorescentia mascula subpaniculata. Flores masculini actinomorhpi; perianthium univerticillatum, lobis triangularibus, stamina duplo quot lobi parvilobis. Inflorescentia feminea racemosa. Flores feminei actinomorhpi, perianthium univerticillatum 5-lobi, sine disco, stylus trifurcatus. Fructus 3-lobi, schizocarpus, stellatopilosus. Semen orbicularis ecarunculata.

Small trees and shrubs 1--4 m tall, dioecious, indumentum of stellate trichomes. Leaves alternate, simple, cordate at base, penninerved, erect-stellate trichomes, estipulate, without glands. Staminate inflorescence subpaniculate. Staminate flowers actinomorphic; perianth 5--merous in a single whorl with triangular lobes; stamens twice as numerous as the perianth divisions; anthers dorsifixed and dehiscing longitudinally; staminate disk weakly lobed. Pistillate inflorescence a raceme. Pistillate flowers actinomorphic, perianth 5--merous, in a single whorl with triangular lobes, without disk, style 3--branched. Fruit a trilobed schizocarp, covered in stellate trichomes. Seeds orbicular and lacking a caruncle. Figure 11.

I have chosen to honor Ricardo G. Garcia, director of the Jardín Botánico Nacional Dr. Rafael M. Moscoso of Dominican Republic (JBSD), for his outstanding contributions and dedication to the botany of Hispaniola. I have suffixed his last name with the greek root, $\delta \dot{\eta} \lambda \mathrm{os}$ (= delos), in reference to the type genus of the Adelineae (i.e., Adelia). 


\section{Key to the species of Garciadelia}

1. Leaf margin revolute, leaf surface bullate from tertiary vein impression, trichomes on

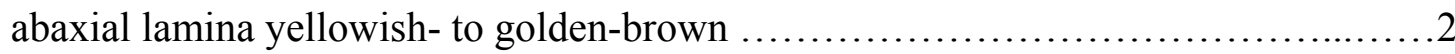

2. Leaves 25-45 mm long, ovate-oblong, apex rounded, entire surface bullate and strongly revolute G. mejiae

2. Leaves 65-120 mm long, lanceolate, apex acute; surface bullate primarily at base and not strongly revolute G. leprosa

1. Leaf margin entire or weakly revolute; leaf surface not bullate but possibly with some tertiary vein impression; trichomes on abaxial lamina white or with occasional browning along the midvein...............................................

3. Leaves coriaceous, elliptic-oblong, symmetric, apex rounded-subacute, tertiary vein impression; trichomes on abaxial lamina with some browning on

midvein G. abbottii

3. Leaves chartaceous, oblanceolate, asymmetric, apex acute, no tertiary vein impression; trichomes on abaxial lamina white G. castilloae

Garciadelia leprosa (Willd.) Jestrow \& Jiménez Rodr., comb. nov. 三 Croton leprosum Willd. Sp. Pl., ed. 4, 4 (1): 553. $1805 \equiv$ Adelia ferruginea Baill. in Étude Euphorb. 418. 1858, nom. superfl. 三 Bernardia leprosa (Willd.) Müll. Arg. Linnaea 34: 172. $1865 \equiv$ Leucocroton leprosus (Willd.) Pax \& K. Hoffm. in Engler: Pflanzenr. IV.147.VII 64. 1914 三 Adelia leprosa (Willd.) Moscoso in Cat. F1. Domingensis 302. 1943 -- Type: Croton leprosum foliis lanceo latis integerrimis cordatis subtus tomentosis. Habitat in St. Domingo, B-W17896. Holotype (B-W!, photo of herbarium 
specimen examined), isotypes [BM!, CGE!, G! (photo of herbarium specimen examined), G-DC! (photo of herbarium specimen examined), P! (photo of herbarium specimen examined)].

$=$ Croton leprosus Spreng. ex Griseb. Fl. Brit. W. I. 38. 1859, nom. illegit.

Shrubs or small trees. Leaves, coriaceous, lanceolate, mucronate and acute apex, cordate base, lamina 6--10 $\mathrm{cm}$ long and 1--2.5 $\mathrm{cm}$ wide, entire to revolute margins, penninerved, adaxial tertiary venation impressed and weakly bullate proximally, brownishyellow to white erect-stellate trichomes, petiole $5--20 \mathrm{~mm}$ long. Staminate inflorescence subpaniculate, 5--10-flowered, $25--40 \mathrm{~mm}$ long. Staminate flowers, petals absent, single whorl of 5-sepals, 2--3 mm long. Pistillate inflorescence raceme, 1--2 flowered, 20--30 mm long, articulate with 1--2 bracts on pedicel 1--2 mm long. Pistillate flowers with single whorl of 5 sepals, 2--3 mm long, pedicel 2--5 mm, style 3--branched. Fruit a trilobed schizocarp, 4$-5 \mathrm{~mm}$ diam. Figure 11A.

Distribution, habitat, and collection history. -- The original description refers to a collection by Pierre Antoine Poiteau from "St. Domingo" without any additional locality (Willdenow, 1805). This was the name for the western half of the island of Hispaniola, now known as Haiti, where Poiteau was collected between 1798 and 1801 (Pennell, 1950). Borhidi (1991) identified the holotype as "POITEAU s.n. Haiti, (G)". I disagree with this typification as it seems that this was not the original material studied by Willdenow. His herbarium (B-W) includes a Poiteau's specimen having a label with the name Croton leprosum that also matches the protologue (Willdenow, 1805). The label of this specimen refers to "St. Domingo" as stated in the original protologue, suggesting this specimen to be 
the holotype for this taxon. All of the other Poiteau collections have on their labels the name "Adelia ferruginea" and the locality "St. Domingue."

The greek noun, $\kappa \rho$ ó $о \varsigma$ (=crotos), is unusual in nomenclature for being a masculine noun ending in "-on" in the third declension. Therefore the specific epithet should follow the masculine ending (e.g., -us) as opposed to the neuter (e.g., -um) (Manara, 1991). Sprengel (1826) recognized this and corrected the orthography by publishing the name as, "Croton leprosus W." All subsequent publications have followed Sprengel's lead, and the name, Croton leprosum, has been abandoned.

Sprengel (1826) assigned further localities and collections from Hispaniola, Martinique, Mexico, and Guadalupe to the name "Croton leprosus W." However, Grisebach (1859) considered that Sprengel (1826) was referring to Croton flocculosus Geis. [accepted name C. flavens L. (Acevedo-Rodriguez \& Strong, 2010)] and not to C. leprosum Willd. In Grisebach's (1859) treatment for C. flocculosus this taxon is listed as "Croton leprosus Spreng (non W.)"; therefore, I am certain that C. leprosus sensu Sprengel does not refer to a taxon of the Leucocroton alliance.

Poiteau's collection of this taxon was the basis for the description of Adelia ferruginea Baill. However, Baillon (1858) did not realize that this species had already been described by Willdenow (1805) 50 years earlier. Because Baillon's description of $A$. ferruginea was based on the same collections used by Willdenow (1805) to describe Croton leprosus, I consider the name A. ferruginea as a nomen superfluum.

While Poiteau (1815a, b) collected in the of Cap-Haïtien region of Haiti, the exact locality is unknown (Fig. 8). The reason for my conjecture of the Cap-Haitien region as the original collection locality is related to the record of Erik Ekman. In 1924, Ekman was the 
second and last botanist to collect Garciadelia leprosa. His collection information details the locality as at the foot of precipices of Eocene limestone near the town Haut-du-Cap, a small town just southwest of Cap-Haïtien. Ekman's material also contains both staminate and pistillate material, making his collections the only known source of pistillate material.

Given the species has not been collected in over eighty years from the single known locality, it has been assigned the IUCN [B1ab(iii)+B2ab(iii)] conservation status of Critically Endangered (IUCN, 2007). I have not considered the species as extinct, because no recent plant exploration has been made to this region to confirm its occurrence.

Garciadelia abbottii Jestrow \& Jiménez Rodr., sp. nov. -- Type: Guettarda. Small tree. Lajana, Samaná Peninsula; altitude about 100 meters. No. 1306 W. L. Abbott, Collector Apr 11, March 27 [crossed out], 1921, US1079094. Holotype (US!), isotypes (BM!, GH!, JBSD!).

Garciadelia leprosa affinis foliis subellipticis obtusis differt.

Shrubs or small trees. Leaves, elliptic-oblong to ovate-oblong, apex rounded to subacute, base weakly cordate, lamina $4--10 \mathrm{~cm}$ in length, margins entire, penninerved, adaxial primary and secondary venation impressed and not bullate, yellow to white trichomes, petiole 7--15 mm long. Staminate inflorescence margins subpaniculate, 10--12 flowered, 20--30 mm long Staminate flowers actinomorphic, single whorl of 5 sepals 2--3 $\mathrm{mm}$ long and ivory-colored adaxially, 10 stamens. Pistillate inflorescence raceme, 1--2 flowered, 30--40 mm long, articulate with 2--3 bracts on pedicel 1--2 mm long. Pistillate flowers actinomorphic with 5 sepals 2--3mm long, pedicel 1--5mm, style 3--branched. Fruit atrilobed schizocarp, 7--9 mm diam., densely stellate. Figure 11E. 
Distribution, habitat, and collection history. -- This species is the most widely collected of the genus with seven known collections. Prior to my study it was identified as Leucocroton leprosus by Urban (1923), R. Howard (1950), Alain (1966), and Liogier (1970). The first collection was by W.L. Abbott in 1921, with the label stating from Lajana, an area of the Samaná Peninsula northeastern Hispaniola. However, because this was the only known collection from the Samaná Peninsula, I researched this locality further. Zanoni (1986) explained that from the $5^{\text {th }}-12^{\text {th }}$ of April, Abbott sailed from the Samaná Peninsula to the southern coast of Samaná Bay. This trip of Abbott coincides with the collection date, and I believe that this serves as confirmation that this first collection is not from the Samaná Peninsula but from coastal areas of Los Haitises, the area from where the species has been collected by the rest of the collectors (Fig. 8). I have chosen the holotype from among four duplicate specimens of Abbott, based on its quality and the high number of staminate inflorescences.

Collecting sites for this species range in altitude from near sea level to ca. $500 \mathrm{~m}$. The low elevation localities are limestone outcrops on the Bahía de Samaná, and even includes red mangroves (Rhizophora mangle L., Rhizophoraceae) as an associated species on a collection label [T. Zanoni, M. Mejía, J. Pimentel 21209 (NY)]. I have found only three living plants of this species (two juveniles and one mature staminate individual) in a single site of Los Haitises, at a karst hill covered with humid evergreen forests.

The species is certainly rare, but I cannot rule out that that more populations exist in unexplored areas of this region. Bolay (1997) wrote about Los Haitises National Park, "Slash-and-burn cultivation goes on and the park cannot be considered well protected. The original territory of $208 \mathrm{sq} \mathrm{km}$ was reduced to only $70 \mathrm{sq} \mathrm{km}$ in 1980.” This information 
allowed us to classify the species as Endangered, according to the IUCN criteria, [B1ab(i,iii)], although I have not been able to visit all known localities of the species.

Garciadelia mejiae Jestrow \& Jiménez Rodr., sp. nov. -- Type: Shrub, 1.75. high; the whole plant golden yellow, aromatic; on limestone rocks, Hoyo de Pelempito, Bahoruco Mts. Alt. 1000 m. Bro. Alain H. Liogier 326 Feb 1971 6, US2649059. Holotype (US!), isotype: (GH!).

Garciadelia leprosa affinis foliis brevis revolutissimis bullatissimis differt.

Shrubs 1--2 m tall. Leaves, coriaceous, narrow-elliptic, mucronate and rounded apex, weakly cordate, no glands, petiole 3--6 mm, lamina 20--40 x 5-10 mm, margins revolute, penninerved, tertiary venation impressed forming a bullate surface, golden-orange erectstellate trichomes, petiole $0.5--1 \mathrm{~cm}$ long, exstipulate. Staminate inflorescence compact, subpaniculate, 5--8 flowered, 20--25 mm long; staminate flowers actinomorphic, sepals 5, 2-$3 \mathrm{~mm}$ long, ivory-colored adaxially, 10 stamens. Pistillate inflorescence axillary racemes, 1-3 flowered, 30--40 mm long with 2--3 bracts on pedicel 1--2 mm long; pistillate flowers actinomorphic with 5 sepals 2--3mm long, pedicel 1--5 mm, style 3--branched. Fruit a trilobed schizocarp, 7--9 mm diam., densely stellate. Figures 11B, 11C, and 11F.

Distribution, habitat, and collection history. -- I first identified the species from two duplicate specimens from a single collection made by Alain Liogier in 1971. These specimens came from a previously unrecorded locality for this genus, in the Bahoruco Mountains, quite distant from the known localities at northwestern (Garciadelia leprosa) and northeastern (G. abbottii) Hispaniola (Fig. 7). Curiously, although Liogier identified these 
specimens as Leucocroton leprosus, he did not include this locality in his Flora of Hispaniola (Liogier, 1986).

When I contacted R. Garcia (JBSD), about these two collections, he informed us about a curious plant he had just recently collected resembling Garciadelia leprosa. Although R. Garcia found this plant in a different site, in the Parque Nacional Sierra de Bahoruco, the locality was close to that of the designed holotype. In 2008, I traveled to the site and collected additional specimens; the collections were morphologically identical to the ones made by Liogier. This population is the largest I have seen for the genus, although numbering fewer than 20 individuals. The altitude was twice that of the other species at ca. 1000 meters. The habitat is dry deciduous forests on kart in a transition towards higher elevation humid evergreen forests. The plants were flowering, and all were dioecious. Only two localities are known for the species, one of which has not been collected since 1971. This species is considered as Endangered according to the IUCN criteria [B1ab(ii)+2ab(ii); D]. I am honoring Milciades Manuel Mejía, former director and botanist of the JBSD, with the eponym Garciadelia mejiae.

Garciadelia castilloae Jestrow \& Jiménez Rodr., sp. nov. -- Type: Sierra del Bahoruco, Provincia Barahona, Municipio La Ciénaga, Seccion La Filipina, márgenes de la Cañada La Baliza, bosque húmedo con Piper spp., Persea sp. Reinhardtia paiewonskiana 17 06' 57” N, 70 06' 27”' W, Elev. 600800 m, 7 Diciembre 2006. T. Clase, B. Peguero \& C. De los Santos, JBSD116910. Holotype (JBSD!) Garciadelia leprosa affinis foliis chartaceis asymmetricis sine impressivenus, trichomatibus albidus abaxialis 
Small spindly trees 3--4 $\mathrm{m}$ tall. Leaves, chartaceous, oblanceolate and asymmetric, mucronate and acute apex, weakly cordate, petiole $10--25 \mathrm{~mm}$, lamina $5--15 \mathrm{~cm}$ long and 20$-45 \mathrm{~mm}$ wide, entire margins, penninerved, only primary venation impressed, white trichomes abaxially. Staminate inflorescence compact, subpaniculate, 5--10 flowered, 50--70 $\mathrm{mm}$ long. Staminate flowers actinomorphic, single whorl of 5 sepals 2--3 mm long, 10 stamens. Pistillate material not known. Figure 11D.

Distribution, habitat, and collection history. -- This species was first discovered in 2006 by T. Clase, B. Peguero, and C. de los Santos and was then tentatively identified as Leucocroton leprosus. While both Garciadelia mejiae and G. castilloae are found in the Bahoruco Mountains, they occur in separate provinces with strikingly different ecosystems and morphologies. Garciadelia castilloae is located in Barahona Province, inland from the town La Filipina, along a roadside surrounded by slash and burn farming. About a dozen mature dioecious plants were seen growing on the side of a steep ravine, with a dense canopy covering a dense underbrush, typical of a humid evergreen forest. Given the slash-and-burn tactics taking place within a mile or two, G. castilloae is one of the most critically endangered species in the Leucocroton alliance. I consider this species to have the Critically Endangered conservation category according to the IUCN guidelines [B1ab(ii)+2ab(ii); C1; D]. I have decided to honor the late Daisy Castillo, botanist of JBSD, with the eponym Garciadelia castilloae. 


\section{LITERATURE CITED}

Acevedo-Rodríguez, P. \& Strong, M.T. 2008. Floristic richness and affinities in the West Indies. Bot. Rev. 74: 5--36.

Acevedo-Rodríguez, P. \& Strong, M.T. 2010. Flora of the West Indies. Catalogue of seed plants of the West Indies. National Museum of Natural History, the Smithsonian Institution, Washington, DC. Published on the Internet:

http://botany.si.edu/antilles/WestIndies/catalog.htm.

Baillon, H.E. 1858. Étude Euphorb générale du groupe de Euphorbiacées. Victor Masson, Paris.

Berry, P.E., Hipp, A.L., Wurdack, K.J., Van Ee, B. \& Riina, R. 2005. Molecular phylogenetics of the giant genus Croton and tribe Crotoneae (Euphorbiaceae sensu stricto) using ITS and trnL-trnF DNA sequence data. Amer. J. Bot. 92: 1520--1534.

Berazain, R., Fuente, V., Rufo, L., Rodríguez, N., Amils, R., Díez-Garretas, B., SánchezMata, D. \& Asensi, A. 2007. Nickel localization in tissues of different hyperaccumulator species of Euphorbiaceae from ultramafic areas of Cuba. Plant Soil. 293: 99--106.

Bolay, E. 1997. The Dominican Republic a country between rain forest and desert. Contributions to the ecology of a Caribbean island. Margraf Verlag, Weikersheim, Germany.

Borhidi, A. 1991. Taxonomic revision of the genus Leucocroton (Euphorbiaceae). Acta Bot. Hung. 36: 13--40.

Castro, N.A. 1978. Bosques. P. 40 in: Instituto Cubano de Geodesia y Cartografía (ed.), Atlas de Cuba. Instituto Cubano de Geodesia y Cartografia, Havana.

Cervantes, A., Stienmann V.W. \& Olvera H.F. 2003. Adelia cinera (Euphorbiaceae), formerly in Bernardia. Brittonia 55: 4--9.

De-Nova, J.A., Sosa, V. \& Wurdack, K.J. 2006. Phylogenetic relationships and the description of a new species of Enriquebeltrania (Euphorbiaceae s.s.): an enigmatic genus endemic to Mexico. Syst. Bot. 31: 533--546.

De-Nova, J.A. \& Sosa, V. 2007. Phylogeny and generic delimitation of Adelia (Euphorbiaceae) inferred from molecular and morphological data. Taxon 56: 1027-1036. 
Downie, S.R. \& Katz-Downie, D.S. 1996. A molecular phylogeny of Apiaceae subfamily Apioideae: evidence from nuclear ribosomal DNA internal transcribed spacer sequences. Amer. J. Bot. 83: 234--251.

Farris, J.S. 1989. The retention index and homoplasy excess. Syst. Zool. 38: 406--407.

Felsenstein, J. 1985. Confidence limits of phylogenies: An approach using bootstrap. Evolution 39: 783--791.

Francisco-Ortega, J., Santiago-Valentín, E., Acevedo-Rodríguez, P., Lewis, C., Pipoly III, J., Meerow, A.W. \& Maunder, M. 2007. Seed plant genera endemic to the Caribbean Island biodiversity hotspot: A review and a molecular phylogenetic perspective. Bot. Rev. 73: 183--234.

Francisco-Ortega, J., Ventosa, I., Oviedo, R., Jiménez, F., Herrera, P., Maunder, M. \& Panero, J.L. 2008. Caribbean Island Asteraceae: Systematics, molecules, and conservation on a biodiversity hotspot. Bot. Rev. 74: 112--131.

Grisebach, A.H.R. 1859. Flora of the British West Indian Islands. Lovell Reeve \& Co., London.

Grisebach, A.H.R. 1861. Erläuterungen ausgewählter pflanzen des tropischen Amerikas. Abh. Königl. Ges. Wiss. Göttingen 9: 3--58.

Huelsenbeck, J.P. \& Ronquist, F. 2001. MrBayes: Bayesian inference of phylogenetic trees. Bioinformatics 17: 754--755.

Humphreys, A.M. \& Linder, H.P. 2009. Concept versus data in delimitation of plant genera. Taxon 58: 1054--1074.

IUCN. 2007. 2007 IUCN red list of threatened species. IUCN Species Survival Commission. IUCN, Gland, Switzerland and Cambridge, UK. Published on the Internet: http://www.iucnredlist.org.

Jestrow, B., Proctor, G. \& Francisco-Ortega, J. 2008. Lasiocroton trelawniensis (Euphorbiaceae), a critically endangered species from the Cockpit Country of Jamaica, belongs to Bernardia (Euphorbiaceae). Bot. Rev. 74: 166--177.

Judd, W.S., Campell, C.S., Kellogg, E.A., Stevens, P.F. \& Donoghue, M.J. 2008. Plant systematics: A phylogenetic approach. $3^{\text {rd }}$ Edition. Sinauer Associates, Sunderland, Massachusetts.

Kluge, A.G. \& Farris, J.S. 1969. Quantitative phyletics and the evolution of anurans. Syst. Zool. 18: 1--32.

Linnaeus, C. 1759. Systema naturae. $10^{\text {th }}$ Edition. Laurentii Salvii, Stockholm. 
Liogier, A.H. 1986. La flora de la Española. Vol. 4. Universidad Central del Este, San Pedro de Macorís, Dominican Republic.

Maddison, D.R., \& W.P., 2000. MacClade 4: Analysis of phylogeny and carácter evolution. Version 4.0 Sinauer Associates, Sunderland, Massachusetts.

Manara, B. 1991. Some guidelines on the use of gender in generic names and species epithets. Taxon 40: 301--308.

Maunder, M., Leiva, A., Santiago-Valentín, E., Stevenson, D.W., Acevedo Rodríguez, P., Meerow, A.W., Mejía, M., Clubbe, C. \& Francisco-Ortega, J. 2008. Plant conservation in the Caribbean Island biodiversity hotspot. Bot. Rev. 74: 197--207.

Motley, T.J., Wurdack, K.J. \& Delprete, P.G. 2005. Molecular systematics of the Catesbaeeae-Chiococceae complex (Rubiaceae): Flower and fruit evolution and biogeographic implications. Amer. J. Bot. 92: 316--329.

Myers N., Mittermeier, R.A., Mittermeier, C.G., Da Fonseca, G.A.B. \& Kent, J. 2000. Biodiversity hotspots for conservation priorities. Nature 403: 853--858.

Nordenstam, B. 2006. New genera and combinations in the Senecioneae of the Greater Antilles. Compositae Newslett. 44: 50--73.

Pax, F. \& Hoffman, K. 1914. Euphorbiaceae-Acalypheae-Mercurialinae. Pp. 1--473 in: A. Engler (ed.), Das Pflanzenreich. IV. 147. VII (63). Wilhelm Engelmann, Berlin.

Pennell, F.W. 1950. Historical collections of the American Philosophical Society and the Academy of Natural Sciences of Philadelphia. Proc. Amer. Philo. Soc. 94: 137--151.

Pelser, P.B., Nordenstam, B., Kadereit, J.W. \& Watson, L.E. 2007. An ITS phylogeny of tribe Senecioneae (Asteraceae) and a new delimitation of Senecio L. Taxon 56: 1077-1104 .

Poiteau, A. 1815a. Exposition des caracter de deux genres de plantes, ou nouveaux, ou incompletement observes, jusqu'a ce jour. Mém. Mus. Hist. Nat. (Paris) 1: 60--65.

Poiteau, A. 1815b. Mémoire sur le genre Drypetes. Mém. Mus. Hist. Nat. (Paris) 1: 152-159.

Posada, D. \& Crandall, K.A. 1998. Modeltest: Testing the model of DNA substitution. Bioinformatics 14: 817--818.

Radcliffe-Smith, A. 2001. Genera Euphorbiacearum. Royal Botanic Gardens, Kew. 
Richard, A. 1850. Segunda parte historia natural. Tomo XI. Botánica. Pp. 1-339 in: R. de la Sagra (ed.), Historia física política natural de la Isla de Cuba. Arthus Bertrand, Paris.

Reeves, R.D., Baker, A.J.M., Borhidi, A. \& Berazaín, R. 1996. Nickel hyperaccumulating plants from the ancient serpentine soils of Cuba. New Phytol. 133: 217--224.

Reeves, R.D., Baker, A.J.M., Borhidi, A. \& Berazaín, R. 1999. Nickel hyperaccumulation in the serpentine flora of Cuba. Ann. Bot. 83: 29--38.

Santiago-Valentín, E. \& Olmstead, R.G. 2004. Historical biogeography of Caribbean plants: Introduction to current knowledge and possibilities from a phylogenetic perspective. Taxon 53: 299--319.

Schaefer, H., Kocyan, A. \& Renner, S.S. 2008. Linnaeosicyos (Cucurbitaceae): A new genus for Trichosanthes amara, the Caribbean sister species of all Sicyeae. Syst. Bot. 33: 349--355.

Shaw, J., Lickey, E.B., Beck, J.T., Farmer, S.B., Liu, W., Miller, J., Siripun, K.C., Winder, C.T., Schilling, E.E. \& Small, R.L. 2005. The tortoise and the hare II: Relative utility of 21 noncoding chloroplast DNA sequences for phylogenetic analysis. Amer. J. Bot. 92: 142--166.

Simmons, M.P. \& Ochoterena, H. 2000. Gaps as characters in sequence-based phylogenetic analyses. Syst. Biol. 49: 369--381.

Smith, M.L., Hedges, S.B., Buck, W., Hemphill, A., Inchaustegui, S., Ivie, M.A., Martina, D., Maunder, M. \& Francisco-Ortega, J. 2004. Caribbean Islands. Pp. 112118 in: Mittermeier, R.A., Gil, R.R., Hoffman, M., Pilgrim, J., Brooks, T., Mittermeier, C.G., Lamoreux, J. \& da Fonseca, G.A.B. (eds.), Hotspots revisited: Earth's biologically richest and most threatened terrestrial ecoregions. Mexico, D.F.: CEMEX.

Sprengel, C.P.J. 1826. Systema vegetabilium. Vol. 3. $16^{\text {th }}$ Edition. Librariae Dieterichianar, Göttingen.

Swofford, D.L. 2003. PAUP*: Phylogenetic analysis using parsimony (*and other methods). Version 4. Sinauer Associates, Sunderland, Massachusetts.

Takahashi, M., Nowicke, J.W., Webster, G., Orli, S.S. \& Yankowski, S. 2000. Pollen morphology, exine structure, and systematics of Acalyphoideae (Euphorbiaceae), part 3 tribes Epiprineae, Adelieae, Alchorneae, Acalypheae pro parte. Rev. Palaeobot. Palynol. 110: 1--66. 
Van Den Berg, C., Higgins, W.E., Dressler, R.L., Whitten, W.M., Soto-Arenas, M.A., Culham, A. \& Chase, M.W. 2000. A phylogenetic analysis of Laeliinae (Orchidaceae) based on sequence data from Internal Transcribed Spacers (ITS) of nuclear ribosomal DNA. Lindleyana 15: 96--114.

Van Den Berg, C., Goldman, D.H., Freudenstein, J.V., Pridgeon, A.M., Cameron, K.M., \& Chase, M.W. 2005. An overview of the phylogenetic relationships within Epidendroideae inferred from multiple DNA regions and recircumscription of Epidendreae and Arethuseae (Orchidaceae). Amer. J. Bot. 92: 613--624.

Webster, G.L. 1975. Conspectus of a new classification of the Euphorbiaceae. Taxon. 24: 593--601.

Webster, G.L. 1994. Synopsis of the genera and suprageneric taxa of Euphorbiaceae. Ann. Missouri Bot. Gard. 81: 33--144.

White, T.J., Bruns, T., Lee, S. \& Taylor, J. 1990. Amplification and direct sequencing of fungal ribosomal RNA genes for phylogenetics. Pp. 315--322 in: Innis, M.A., Gelfand, D. H., Sninsky, J.J. \& White, T.J. (eds.), PCR protocols: A guide to methods and applications. Academic Press, San Diego, California.

Willdenow, K.L. 1805. Species plantarum. Volume 4, part 1. $4^{\text {th }}$ Edition. G. C. Nauk, Berlin.

Wurdack, K.J., Hoffmann, P. \& Chase, M.W. 2005. Molecular phylogenetic analysis of uniovulate Euphorbiaceae (Euphorbiaceae sensu stricto) using plastid rbcL and trnLF DNA sequences. Amer. J. Bot. 92: 1397--1420.

Zanoni, T.A. 1986. Las expediciones botánicas de Wiliam L. Abbott y Emery C. Leonard a la isla de la Española. Moscosoa. 4: 6--38. 
Fig. 4. One of the 14 most parsimonious trees from the analysis of ITS nucleotide sequences. This tree was identical to the $50 \%$ majority rule consensus tree inferred from the Bayesian analysis except for the branch indicated with "*". This branch collapsed in the Bayesian topology. Number of steps along each branch are indicated in italics. Bootstrap values from parsimony analysis are above branches, clade credibility values from Bayesian analysis are below branches. This tree was identical to the strict consensus tree obtained after the parsimony analysis.

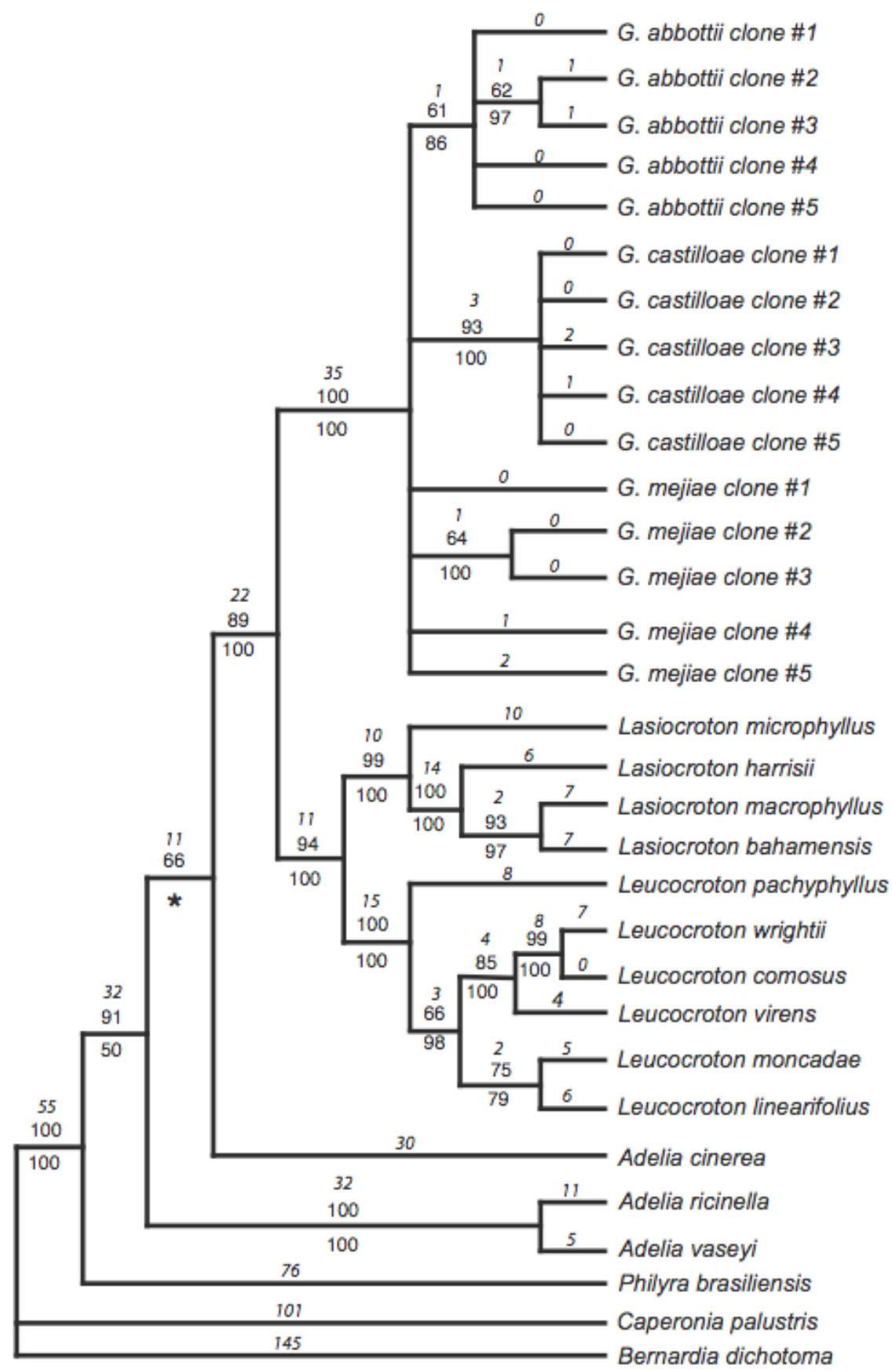


Fig. 5. Topologies recovered after parsimony analyses of nucleotide sequences of the two regions of the chloroplast genome. Top, One of the six most parsimonious trees from the analysis of $p s b M-t r n D$ nucleotide sequences. The branch that collapses in the strict consensus tree is indicated with an arrow. Bottom, The single most parsimonious tree from the analysis of $y c f 6-p c b M$ nucleotide sequences. Trees were identical to the $50 \%$ majority rule consensus tree inferred from the Bayesian analyses except for the branches indicated with "*". These branches collapsed in the Bayesian topologies. Numbers of steps for each branch are indicated in italics. Bootstrap values ( $>50 \%)$ from parsimony analysis are above branches, clade credibility values from Bayesian analysis are below branches. An additional conflict between the Bayesian and parsimony topologies ( $p c b M-t r n D$ data set) was detected for the branch indicated with "\#”.
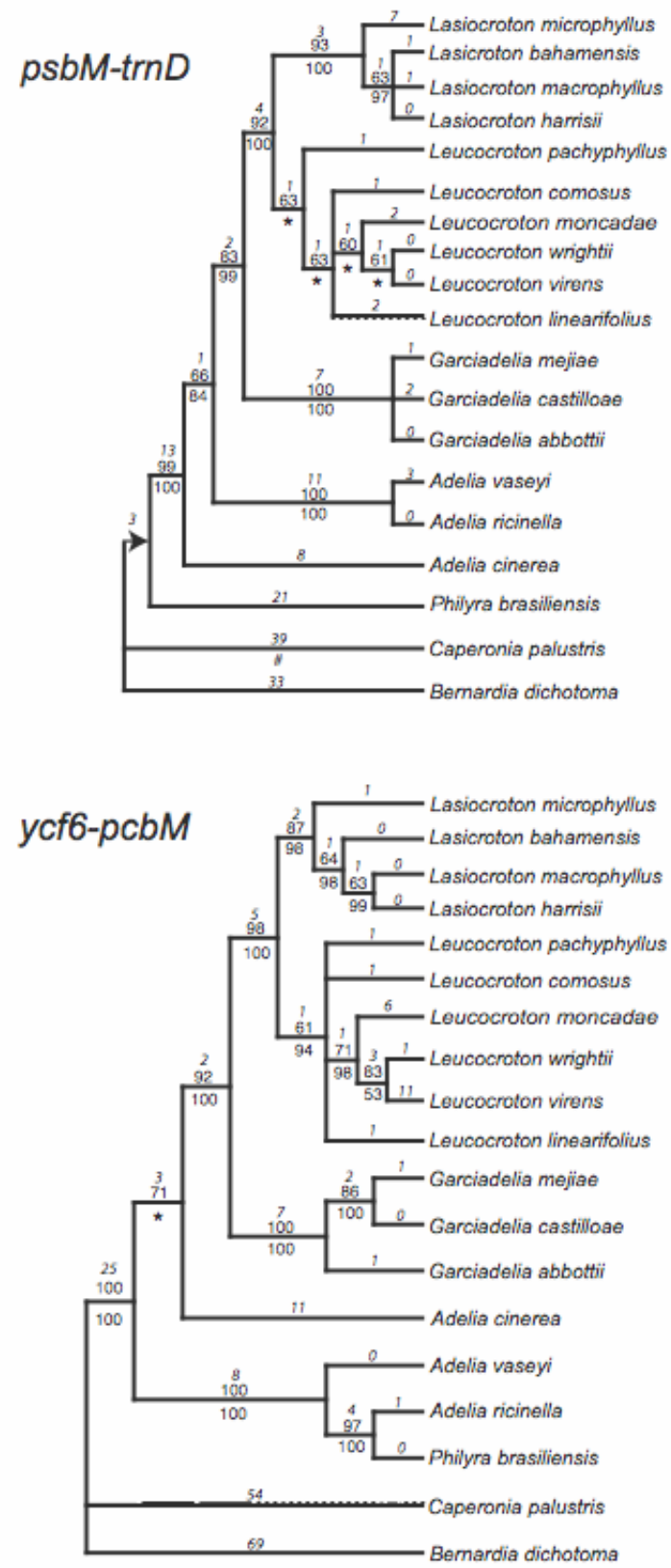
Fig. 6. The single most parsimonious tree from the analysis of the combined datasets. This tree was identical to the $50 \%$ majority rule consensus tree inferred from the Bayesian analysis except for the branch indicated with "*". This branch collapsed in the Bayesian topology. Bootstrap values $(>50 \%)$ from parsimony analysis are above branches, clade credibility values from Bayesian analysis are below branches. An additional conflict between the Bayesian and parsimony topologies was detected for the branch indicated with "\#". Number of steps along each branch, according to the Deltran algorithm, are indicated above the bootstrap values in italics. The expected rate of change per character (x1000 for scale) from the Bayesian analysis is shown in italics below the clade credibility values.

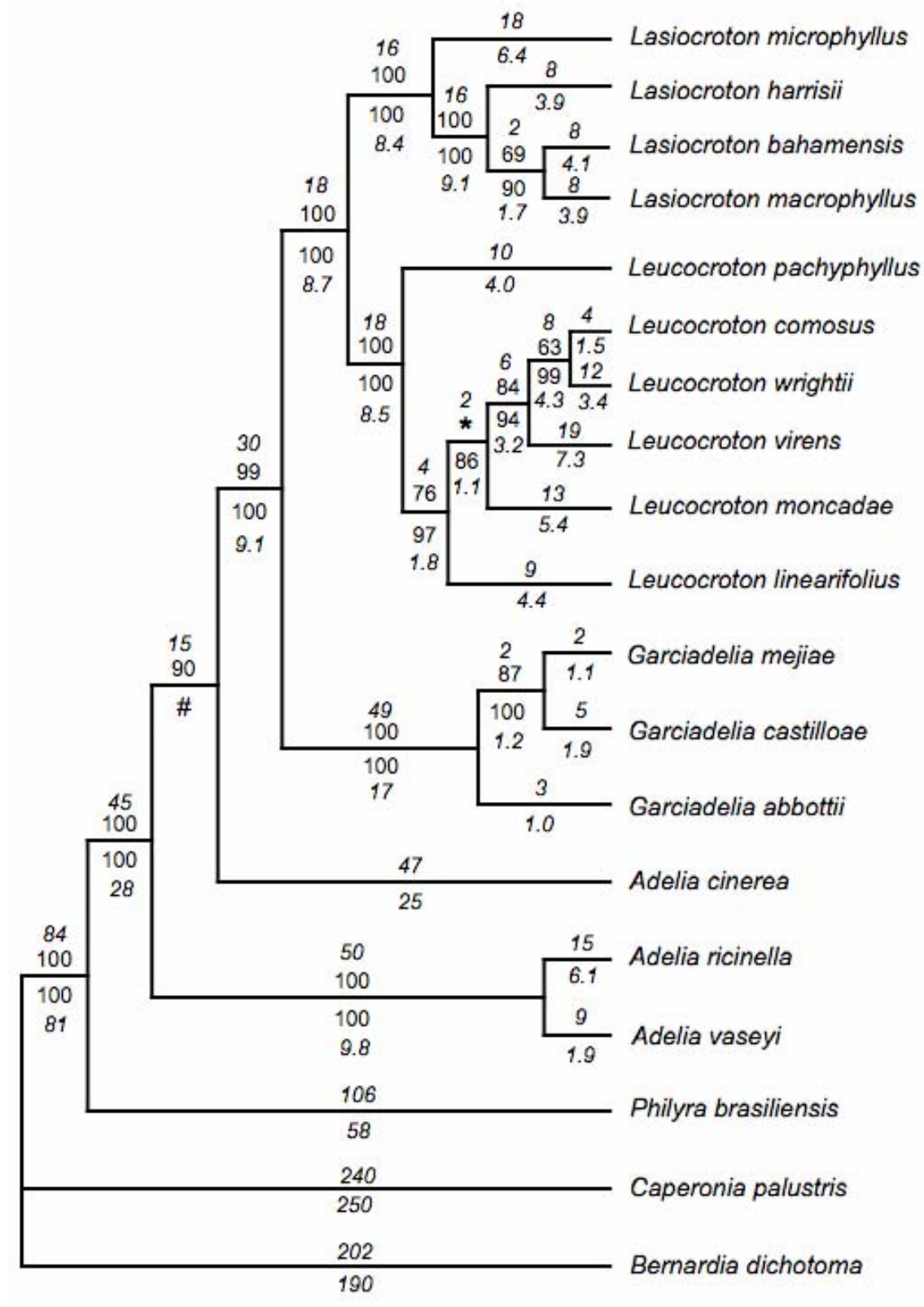


Fig. 7. SEM of pollen of the Leucocroton alliance. A, Garciadelia mejiae. B, G. castilloae. C, G. abbottii. D, Lasiocroton bahamensis. E, L. harrisii. F, L. microphyllus. G, Leucocroton pachyphyllus, H, L. virens, I, L. linearifolius.
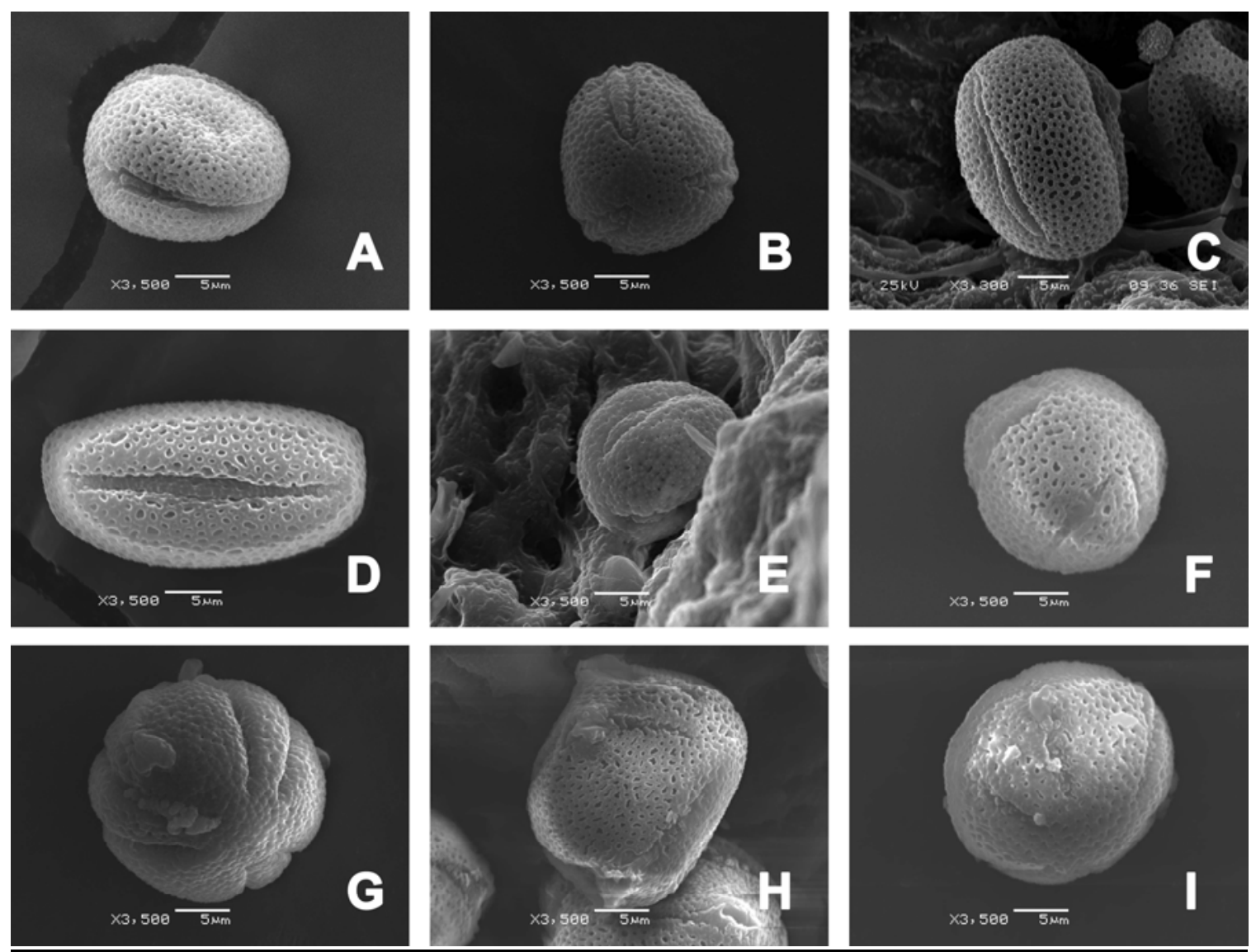
Fig. 8. Map of Hispaniola showing the known localities of the four species of Garciadelia. Triangle, G. abbottii. Square, G. castilloae, Circle, G. leprosa. Star, G. mejiae.

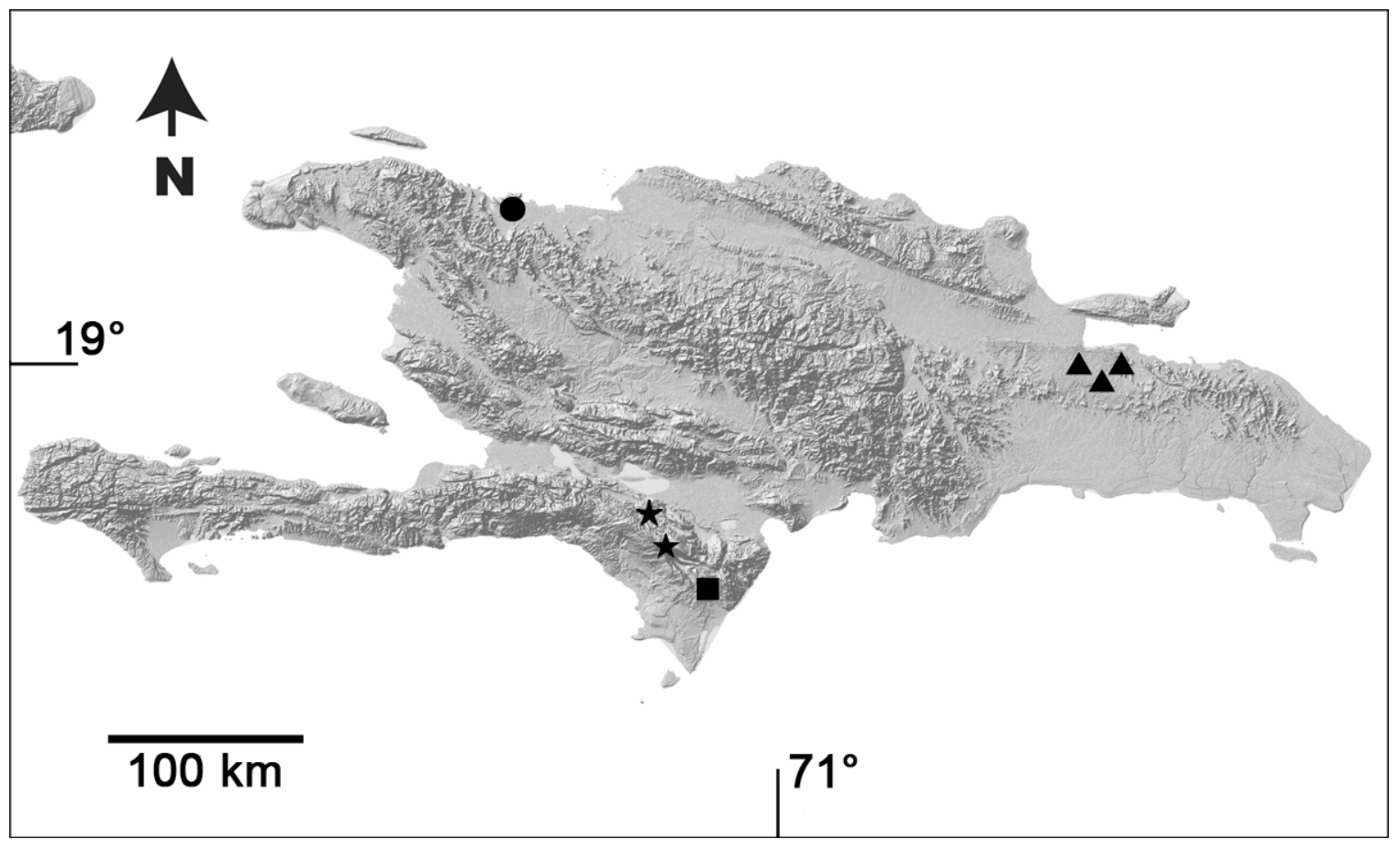


Fig. 9. Map of Cuba showing the known localities for the new species of Lasiocroton described in this study. Diamond, L. gutierrezii.

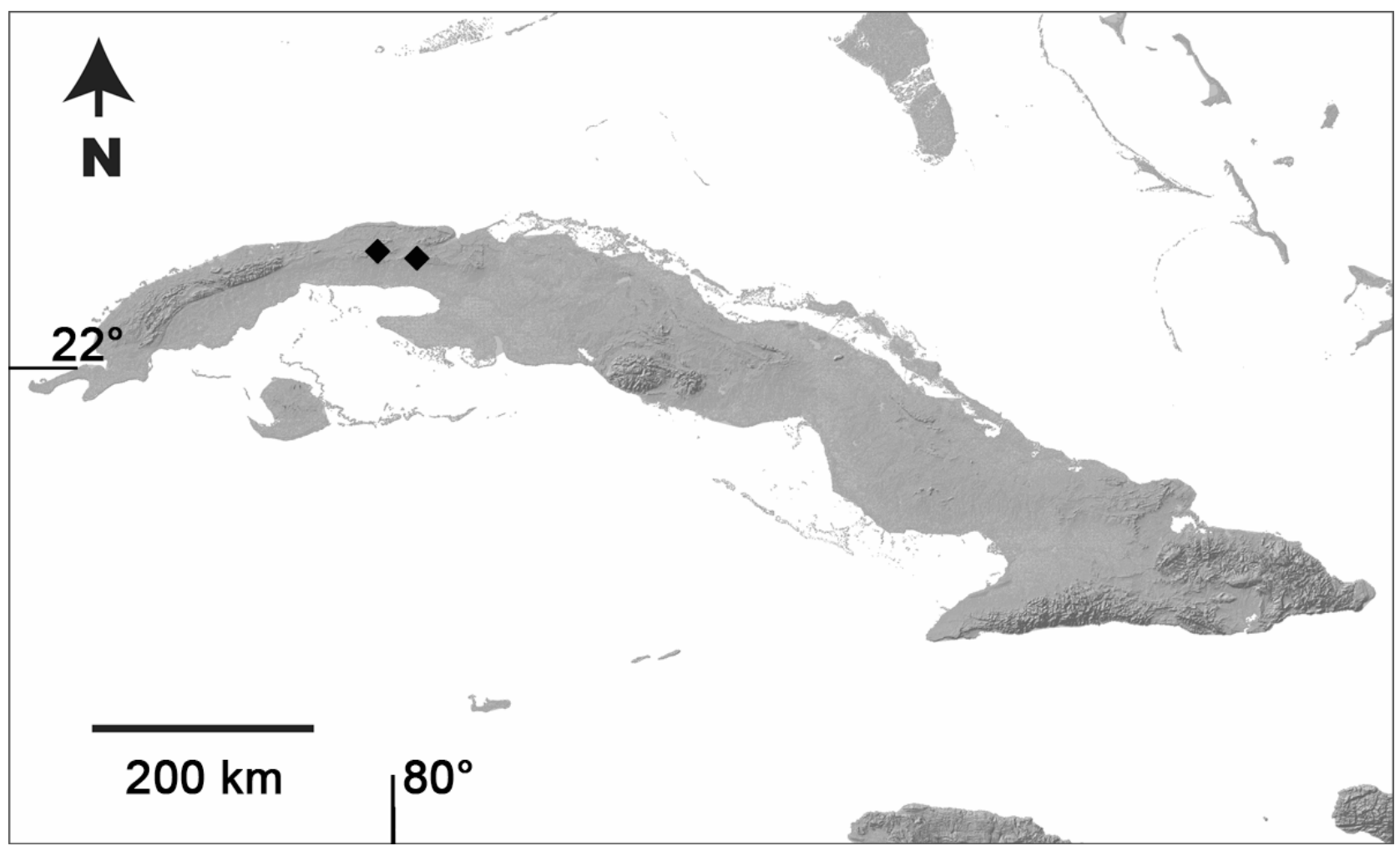


Fig. 10. Lasiocroton gutierrezii. A, Flower, pistillate. B, Flower, staminate. C, Branch, fertile pistillate. D, Branch, fertile staminate. (A, C, from J. Acuña \& Roig 16912; B, D, from Alain 5289).
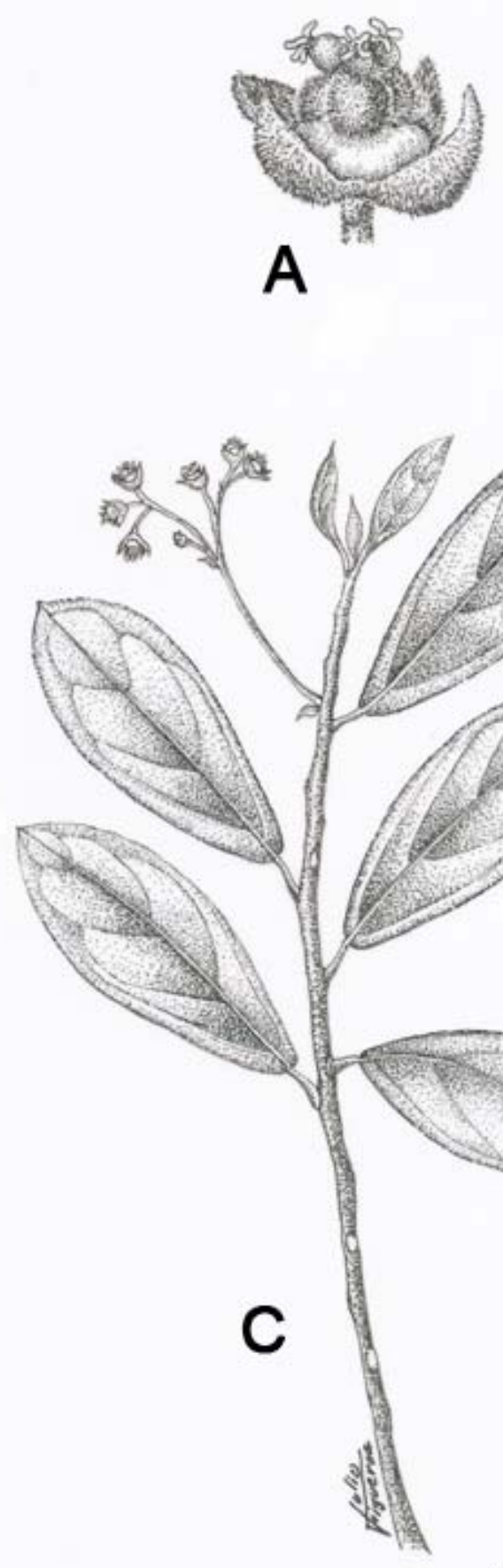

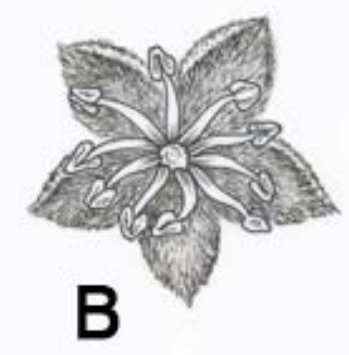


Fig. 11. Garciadelia. A, G. leprosa, Branch, staminate. B, G. mejiae, Inflorescence, pistillate. C, G. mejiae, Flower, staminate. D, G. castilloae, Leaf. E, G. abbottii, Leaf. F, G. mejiae, Leaf. (A, from Poiteau s.n.; B, from Jestrow \& F. Jiménez 1019; C, from Jestrow \& F. Jiménez 1018; D, from Jestrow \& Jiménez 1020; E, from W.L. Abbott 1306; F, Liogier 326).

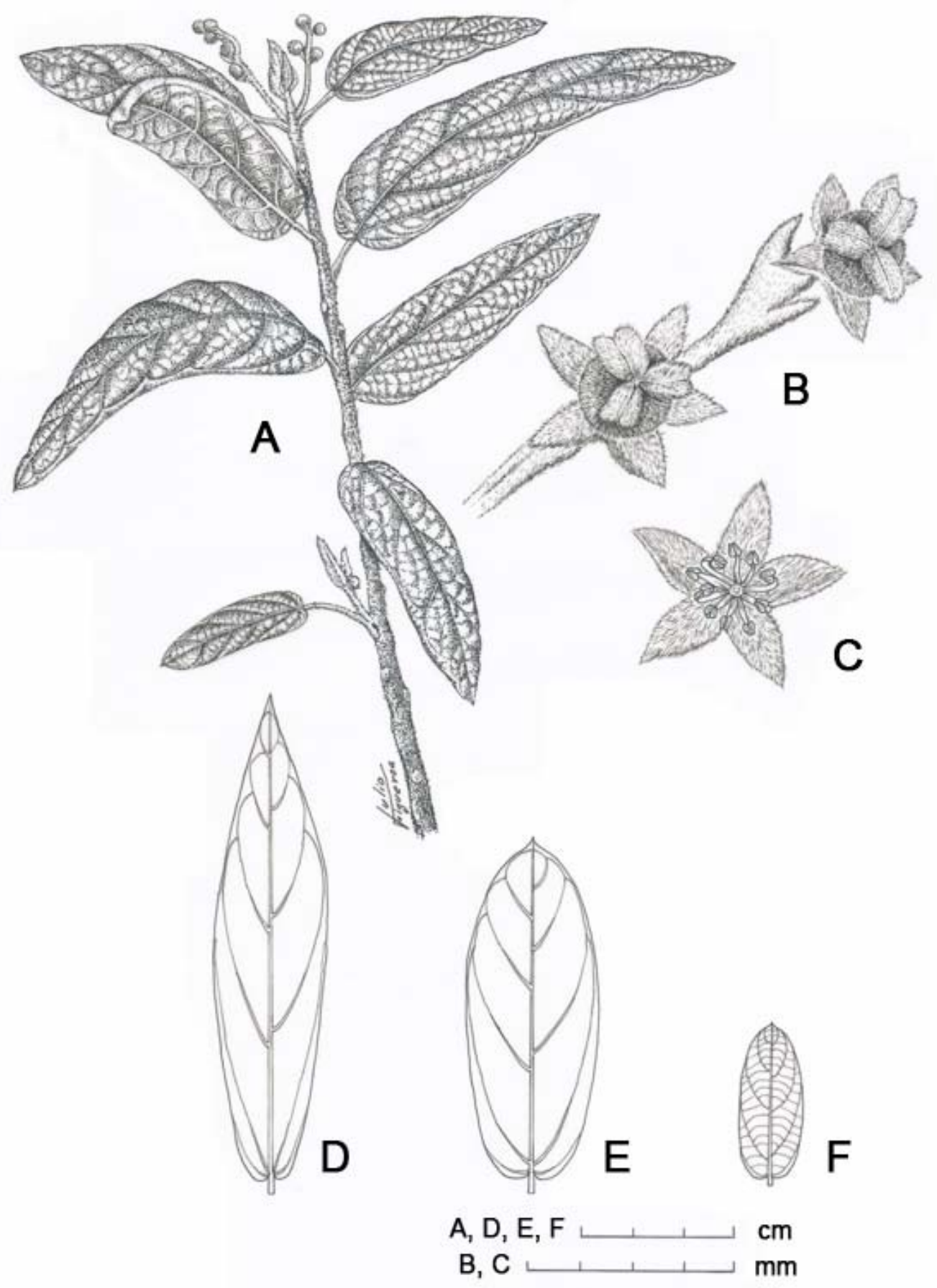


Table 2. Parsimony statistics of tree topologies.

\begin{tabular}{|c|c|c|c|c|c|c|}
\hline DNA region & AL & $\mathrm{N}$ & Total PI & LA PI & MPT & $\mathrm{CI} / \mathrm{RI} / \mathrm{RC}$ \\
\hline ITS & $764(7)$ & $19(15)$ & $175(5)$ & $89(3)$ & $14(689)$ & $0.66 / 0.81 / 0.62$ \\
\hline pcbM-trnD & $1065(42)$ & 19 & $38(15)$ & $8(10)$ & $6(171)$ & $0.78 / 0.86 / 0.78$ \\
\hline усf6-pcbM & $1222(45)$ & 19 & $43(16)$ & $16(7)$ & $1(224)$ & $0.83 / 0.91 / 0.85$ \\
\hline Combined data set & $3051(94)$ & 19 & $252(36)$ & $109(20)$ & $1(1056)$ & $0.67 / 0.75 / 0.61$ \\
\hline
\end{tabular}

$\mathrm{AL}=$ alignment length (number of coded gaps); $\mathrm{N}=$ number of taxa (number of sequenced clones); Total PI = total parsimony informative nucleotides (number of parsimony informative coded gaps); LA PI = parsimony informative nucleotides within the Leucocroton alliance (number of PI coded gaps); MPT = number of most parsimonious trees (tree score); $\mathrm{CI} / \mathrm{RI} / \mathrm{RC}=\mathrm{consistency}$ index excluding uninformative characters, retention index, and rescaled consistency index 
Appendix. Species names, voucher information, specimens examined $(*=$ photo of herbarium specimen was examined), pollen voucher specimens (\#), and Genbank accession numbers for the sequences used in the molecular analyses (ITS, pcbM-trnD, ycf6-pcbM, respectively).

Adelia cinerea (Wiggins \& Rollins) A. Cerv., V. W. Steinm. \& Flores Olv.; Mexico; Steinmann 971 (RSA); GU000027; GU000042; GU000048. Adelia ricinella L.; Cuba; HAJB 81949 (FTG); GU000023; GU000045; GU000049. Adelia vaseyi (J.M. Coult.) Pax \& K.Hoffm.; Mexico; De-Nova 191 (XAL); GU000026; GU000043; GU000050. Bernardia dichotoma Müll. Arg.; Jamaica; Jestrow 1001 (FTG); GU000029; GU000047; GU000051. Caperonia palustris A. St.-Hil.; USA; GU000030; GU000046; GU000052. Garciadelia abbottii Jestrow \& Jiménez Rodr.; Dominican Republic; W.L. Abbott 1306 (BM, GH, JBSD, US); P. Acevedo-Rodríguez. 8571 (JBSD); Ekman 15393 (US); F. Jiménez, A. Veloz \& B. Peguero 3577 (FTG\#); clone1 GU000002; clone2 GU000003; clone3 GU000004; clone4 GU000005; clone5 GU000006; GU000041; GU000055; A. H. Liogier 14495 (GH, NY); T. Zanoni, M. Mejía \& J. Pimentel 21209 (NY); T. Zanoni, M. Mejía, J. Pimentel \& R. García 34204 (JBSD). Garciadelia castilloae Jestrow \& Jiménez Rodr.; Dominican Republic; $T$. Clase, B. Peguero \& C. De los Santos 4341 (JBSD); Jestrow \& Jiménez 1020 (FTG\#); clone1 GU000007; clone2 GU000008; clone3 GU000009; clone4 GU000010; clone5 GU000011; GU000040; GU000053. Garciadelia leprosa (Willd.) Jestrow \& Jiménez Rodr.; Haiti. Ekman 2726 (IJ, K, NY, S, US); Poiteau s.n. (B-W*, BM, CGE, G*, G-DC*, P*). Garciadelia mejiae Jestrow \& Jiménez Rodr.; Dominican Republic; R. García, G. Caminero \& D. Höner 4409-A (JBSD); Jestrow \& F. Jiménez 1018 (FTG*); clone1 GU000012; clone2 
GU000013; clone3 GU000014; clone4 GU000015; clone5 GU000016; GU000039; GU000054; Jestrow \& F. Jiménez 1019 (FTG); Liogier 326 (GH, NY); F. Jiménez, R. García \& R. Rodríguez 4152 (FTG, JBSD). Lasiocroton bahamensis Pax \& K. Hoffm.; Bahamas; W. Gillis 10451 ex situ (FTG\#); GU000024; GU000032; GU000056. Lasiocroton gutierrezii Jestrow; Cuba. Alain 5289 (GH, HAC); J. Acuña \& Roig 16912 (HAC). Lasiocroton harrisii Britton; Jamaica; Jestrow 1009 (FTG); GU000018; GU000033; GU000057; Jestrow 1010 (FTG\#). Lasiocroton macrophyllus (Sw.) Griseb.; Jamaica; Jestrow 1002 (FTG); HM185116; HM185117; HM185118. Lasiocroton microphyllus (A. Rich) Jestrow; Cuba; J. Acuña 17846 (HAC*); J. Acuña \& Correll 18667 (HAC*, HAJB*); Bro. Alain 5289 (GH); Bisse \& al. HAJB 29791 (HAC*); Britton \& al. 5619 (F, NY); A. Areces \& al. 31330 HAJB (HAC*, HAJB*); Britton \& al. 5675 (F, NY); Britton \& al. 5980 (F, NY); Britton \& al. 6244 (F, NY); Britton \& al. 13979 (NY); G. Bucher (NY); I. Castañeda \& I. Alemán 1363 (HAC*); Bro. Clemente 1223 (HAC*); Bro. Clemente 3039 (HAC*, HAJB*, NY, US); Bro. Clemente 3259 (HAC*); Bro. Clemente 5724 (GH, HAC*, US); Bro. Clemente 7223 (GH, US); Bro. Clemente 7534 (GH, HAC*); R. Comb. 575 (F, GH, K, NY); Ekman 398 (S); Ekman 334 (S); Ekman 1100 (F, MGE, S); Ekman 8920 (K); Ekman 13317 (S); Ekman 13659 (S); Ekman 15534 (NY, S, US); Greene 4 (K*); J. Grudzinskaya \& N. Tuchanitzkaja 454 (HAC*); Gutiérrez \& al. 81915 (FTG); Gutiérrez \& al. 81947 (FTG\#); GU000017; GU000031; GU000058; Gutiérrez \& al. 81839 (FTG); $R$. Howard \& al. 4 (A); E.P. Killip 13826 (US); Bro. León 2908 (NY, HAC*); Bro. León 6865 (NY); Bro. León 7177 (GH, HAC*, NYBG); Bro. León 9084 (NY); Bro. León 10655 (HAC*); M. López 61 (HAJB*, US); M. López 62 (HAC*); M. López 173 (HAC*, HAJB*, US); M. López 1048 (HAC*, HAJB*); M. López 1138 (HAJB*); M. López 1177 (HAC*, 
HAJB*); Moldruke, Bro. León, Bro. Alain \& J. Acuña 16913 (HAC*); G. Proctor 16424 (A, IJ); R. de la Sagra (P*, G-DC*, G-DC*); G.L. Webster 83 (A); G.L. Webster 4046 (GH, MGR, NY, US); G.L. Webster 4047 (US, MGR); C. Wright 1977 (BM, F, G-DC*, GH, HAC*, HAJB*, K, NY, S). Leucocroton comosus Urb.; Cuba; Gutiérrez \& al. 81722 (FTG); GU000020; GU000035; GU000059. Leucocroton linearifolius Britton; Cuba; Berazaín 71542 (US\#); Gutiérrez \& al. 81807 (FTG); GU000022; GU000038; GU000060.

Leucocroton moncadae Borhidi; Cuba; Gutiérrez \& al. 84363 (HAJB); GU000021; GU000036; GU000061. Leucocroton pachyphyllus Urb.; Cuba; Gutiérrez \& al. 81896 (FTG); GU000019; GU000034; GU000062; Shafer 4164 (US\#). Leucocroton virens Griseb.; Cuba; Bro. Alaín \& Bro. Clemente 1002 (US\#); Gutiérrez \& al. 81851 (FTG); GU000025; GU000037; GU000063. Leucocroton wrightii Griseb.; Cuba; Bennet 7590 (FTG); HM185119; HM185120; HM185121. Philyra brasiliensis Klotzsch.; Brazil; Thomas \& al. 12565 (NY); GU000028; GU000044; GU000064. 


\section{CHAPTER III}

Islands within Islands; a Molecular Phylogenetic Study of a Plant Radiation across the Serpentine Archipelago of Cuba

Brett Jestrow $^{1,2, *}$, Jorge Gutiérrez ${ }^{3}$ and Javier Francisco-Ortega ${ }^{1,2}$

- ${ }^{1}$ Department of Biological Sciences, Florida International University, Miami, FL, USA, ${ }^{2}$ Center for Tropical Plant Conservation, Fairchild Tropical Botanical Garden, Coral Gables, FL, USA, and ${ }^{3}$ Jardín Botánico Nacional, Habana, Cuba

\footnotetext{
*Correspondence: Brett Jestrow, Department of Biological Sciences, Florida International University, Miami, FL, USA

E-mail: bjest001@fiu.edu
} 


\begin{abstract}
Aim My aim was to investigate the historical biogeography of the three genera, Garciadelia Jestrow \& Jiménez Rodr., Lasiocroton Griseb., and Leucocroton Griseb. (Euphorbiaceae) known collectively as the Leucocroton alliance.
\end{abstract}

Location Garciadelia (endemic to Hispaniola) and Lasiocroton (restricted to the Bahamas, Cuba, and Jamaica) thrive on limestone soils. Leucocroton is endemic to serpentine soil regions across Cuba.

Methods Members of the Leucocroton alliance along with representatives from tribe Adelieae (Adelia L. and Philyra Klotzsch.) were included in a molecular phylogenetic analysis based upon nucleotide sequences of the internal transcribed spacers of the nuclear ribosomal DNA and the non-coding chloroplasts regions, $p s b M-t r n D$ and $y c f 6-p c b M$. I included 37 collections representing 28 species.

Results Phylogenetic analyses support the monophyly of the three genera. Incongruence tests identified conflicts among the three data sets; the major topological incongruence concerned the placement of Lasiocroton macrophyllus (Sw.) Griseb. The chloroplast phylogenies and the Bayesian analyses of the combined ITS-cpDNA data set placed this taxon as sister to two other Jamaican species (i.e., L. fawcettii Urb., and L. harrisii Britton). In contrast the other phylogenetic analyses supported a clade formed by this species and the widespread L. bahamensis Pax \& K.Hoffm. Multiple accessions of five species formed distinct clades, supporting them as distinct taxa. In contrast, multiple accessions for two 
species did not form two distinct monophyletic groups. Phylogenetic relationships within these groups, however, received low statistical support. The ancestral area of the Leucocroton alliance is Eastern Cuba and Hispaniola. Ancestral forms of Leucocroton arose on eastern Cuba and underwent two migrations across the island. The ancestor of Lasiocroton also originated on Eastern Cuba followed by later dispersal and speciation events to the other islands. My study also suggests that ancestral forms of the Leucocroton alliance most likely occurred on limestone soils.

Main conclusions My study concurs with previous hypotheses suggesting that the flora of serpentinite regions of the Caribbean derives from other types of soils. The serpentine endemics of the Leucocroton alliance have a single origin and represent one of the most extraordinary examples of speciation in this unique environment of the New World. The high colonization success achieved by the members of Leucocroton on serpentine soils was not attained by the other genera of the alliance, which occur on limestone areas.

\section{Keywords}

Caribbean Islands, Adelia, Garciadelia, Lasiocroton, Leucocroton, nickel, hyperaccumulator, phylogeography, serpentine, ultramafic 


\section{INTRODUCTION}

Most molecular phylogenetic studies concerning plant adaptive radiation of insular systems focus on remote volcanic oceanic islands such as the Galápagos, the Hawaiian Archipelago, Juan Fernández, Macaronesia, and St. Helena (Andrus et al., 2009; Eastwood et al. 2004; Francisco-Ortega et al., 1996; Price \& Wagner, 2004; Ruiz et al., 2004; Trusty et al., 2005;).

Fewer studies have targeted larger tropical systems such as the Caribbean Islands, Indonesia, Malesia, and the Philipines. As opposed to the volcanic oceanic islands, these other tropical islands have complex geologies and broad soil diversities as they follow the ophiolitic regions of the orogenic belts (Brooks, 1987).

With over 1,000 islands and islets, the West Indies are unique because of their ancient isolation from the mainland. According to the Gaarlandia hypothesis, the most recent landbridge between these islands and the mainland dates to the Eocene-Oligocene boundary ( $\sim 34$ Ma) and connected the Greater Antilles with South America through the Aves Ridge (Iturralde-Vinent \& MacPhee, 1999), a geographic connection significantly older than the well known land-bridges that joined Indonesia, Malesia, and the Philippines with the Asian continent during the Pleistocene (Voris, 2000).

Another point of interest of the West Indies is the presence of ultramafic rocks, rocks which consist of more than $70 \%$ mafic (i.e., magnesium-iron based) silicate minerals. The vast majority of these rocks are intrusive and are either metamorphic (e.g., serpentinite) or igneous (e.g., peridotite). The ultramafic rocks occur on all large tropical island systems in disproportion to their occurrence on continents, unlike the oceanic volcanic islands, where this rock type is virtually nonexistent (Révillon et al., 2000). While less than $1 \%$ of the earth's terrestrial surface consists of ultramafic rock (Brooks, 1987), Cuba is covered by 
about 7\% of ultraqmafic rock (Reeves et al. 1999). New Caledonia is an exceptional example with nearly a third of its geological substrate composed of ultramafic rocks (Jaffré, 1980). Within the Greater Antilles, ultramafic rocks occur on Cuba, Hispaniola, Jamaica, and Puerto Rico (Lewis et al., 2006), while a single ultramafic area of Jamaica encompasses a very small patch of $0.25 \mathrm{~km}^{2}$ (Abbott et al., 1999). In tropical regions, nickel lateritic soils usually develop from ultramafic rocks through weathering processes. Depending on the specific mineral constituents of the ultramafic substrate, these soils are identifiable by their high magnesium to calcium ratios as well as high levels of the metals nickel and cobalt; these characteristics exert selective pressures on the plants growing on them. High selection pressure is the typical case for the Caribbean Island ultramafic laterites, generally referred to as serpentine soils in biological literature (Brooks, 1987).

Botanists have recognized the correlation of ultramafic substrates with unusual floras for hundreds of years (Brooks, 1987). Morphological tendencies such as sclerophylly, microphylly, and other traits related to xeromorphism are typical for plants inhabiting these soils in the tropics (Borhidi, 1996). Despite the dramatic morphologies, few biogeographical studies have used molecular tools to understand the origin and evolution of insular floras thriving on this unique habitat. Most such studies have focused on continental regions with small radiations over serpentine areas, as in the Mediterranean, Asia Minor, and California (e.g., Cecchi \& Selvi, 2009; Nguyen et al., 2008). Serpentine radiations within tropical islands are even more poorly researched. The remote island of New Caledonia has been the subject of two recent studies of members of the Cunoniaceae. One study focused on Codia J.R. Forst \& G. Forst with seven serpentine obligate endemic species (Pillon et al., 2009a), and the other was on Spiraeanthemum A. Gray with three serpentine obligate endemic 
species (Pillon et al., 2009b, 2009c). These studies focused on describing the reticulate evolution and hybridization within the respective genera. A similar paucity of research exists for the Caribbean Islands, with most relevant studies being taxonomic in nature with little or no reference to soil types (see Discussion below). As far as I am aware, no molecular phylogenies focusing on large radiations of West Indian plants endemic to serpentine soils have been produced, though many potential genera exist. For instance, Calyptranthes Sw. (Myrtaceae), Eugenia L. (Myrtaceae), Ossaea DC. (Melastomataceae), and Rondeletia L. (Rubiaceae) each have over twenty species of serpentine obligates within Cuba (Reeves, 1999).

Many of the species found on these soils are serpentine obligates, but only a subset of species are nickel hyperaccumulators. Plants described as Ni-hyperaccumulators have over $1,000 \mu \mathrm{g} / \mathrm{g}$ nickel per dry plant material; this is between one and two orders of magnitude higher than a typical serpentine obligate (Reeves et al., 1999). Nickel, though a required nutrient, is typically found in very low concentrations in non-serpentine land plants, and is considered toxic at the high levels found in many serpentine soils. Physiologically, serpentine plants must deal with the heavy metal either by hyperaccumulation or by inhibiting their uptake at the root-soil interfaces (Verbruggen et al., 2008). The world total of Nihyperaccumulators has last been tallied at only 390 species (Verbruggen et al., 2008), although new hyperaccumulators are routinely identified (Ghaderian et al., 2007; Reeves et al., 2007). Other metal hyperaccumulators are known ( 450 hyperaccumulating species in total; Verbruggen et al., 2008), but those dealing with nickel ( 90\%) represent the majority. From a biogeographic perspective, several studies consider Ni-hyperaccumulation as a syndrome of paleoendemism, arguing that the required complex metabolic pathways for 
hyperaccumulation imply significant evolutionary change and can only have originated in ancient groups (Borhidi, 1996; Reeves et al., 1999).

Cuba, with over 150 species of Ni-hyperaccumulators, ranks highly in global importance for diversity of hyperaccumulators. While Ni-hyperaccumulation has been identified in many different genera within the flora of this island, three are particularly species-rich. Two of them, (i.e., Buxus L. (Buxaceae) and Phyllanthus L. (Phyllanthaceae)), have wide distributions outside Cuba (Reeves et al., 1999). These are taxonomically difficult genera, with a large number of endemic species on Cuba (Buxus: 37 species; Phyllantus: 53 species and subspecies) and occurring on a wide array of soils and ecosystems. Buxus has 17 Ni-hyperaccumulating endemic species, whereas Phyllanthus has 25 . The third genus, the focus of this research, is the Cuban endemic taxon Leucocroton Griseb. (Euphorbiaceae) (Fig. 1). Leucocroton has more Ni-hyperaccumulating species than any other genus within the Caribbean Islands (Bordács \& Borhidi, 1993; Borhidi, 1991, 1996; Borhidi et al. 1992; Reeves et al., 1996, 1999). The present delimitation of Leucocroton (Jestrow et al., in press) includes 26 species; all are Ni-hyperaccumulators restricted to the serpentine soil areas across Cuba.

Lewis et al. (2006) divide the ultramafic substrates of Cuba into ten primary massifs distributed from the western to the eastern extremes of the island (Fig. 2). All of the massifs are metamorphic in origin and have undergone varying amounts of serpentinization, therefore the ultramafic rocks of Cuba can be broadly classified as serpentinite. On the basis of their developmental age, the soils formed on these massifs are divided into two major groups. Finko et al. (1967) identify the western massif region, Cajálbana and the two Eastern massifs, Mayarí-Cristal and Moa-Baracoa, as having mature soils ranging from 10-30 Ma. 
The other massifs of central Cuba are considered to be much younger at about $1 \mathrm{Ma}$ or less (Finko et al., 1967). However, Lewis et al. (2006) suggest that the soil development of the central Cuban massif Camagüey to date to the Miocene (5-20 Ma), with the laterites of Camagüey having undergone significant erosion into neighboring sedimentary basins. While the proposed ages and constituent minerals of these massifs differ, species of Leucocroton are known to occur on eight of these massifs from western, central, and eastern Cuba (Fig. 2). This serpentine obligate genus has diversified throughout the serpentine archipelago of Cuba, representing a unique evolutionary model system within the Caribbean Islands.

Leucocroton together with Garciadelia Jestrow \& Jiménez Rodr. and Lasiocroton Griseb., constitute the Leucocroton alliance, a monophyletic group endemic to the West Indies (Francisco-Ortega et al., 2007) (Fig. 1). Garciadelia is restricted to Hispaniola, whereas Lasiocroton has a wider distribution of the Bahamas, Cuba, Hispaniola, and Jamaica (Fig. 3). Members of this alliance are woody, long-lived, evergreen plants ranging from small shrubs to canopy trees (Fig. 1). All members of the alliance are dioecious. Though no field pollination study exists for the group, I consider most of the alliance putatively to be windpollinated, as most of the species exhibit many of the wind-pollination syndromes described by Freidman and Barrett (2009) (e.g., many flowers, small or absent petals, greenish or white flowers, unscented flowers, few ovules per flower, unvarying pollen size, massive pollen production, lack of pollen ornamentation, unisexual flowers, synchronous flowering, and occurrence in open habitats with high conspecific density).

In a prior taxonomic study, I defined the Leucocroton-alliance as a clade within the tribe Adelieae (Jestrow et al., 2008, in press). This tribe is composed of two additional genera: Adelia L., and Phylira Klotzsch. The former is found on the continent from Mexico 
south to Brazil with a single species, A. ricinella L., reaching the Caribbean Islands. Philyra is native to Eastern South America.

Because Garciadelia (four species) and Lasiocroton (seven species) are restricted to limestone areas, while Leucocroton is endemic to serpentine soils, the Leucocroton alliance has a unique biogeography, including taxa occurring on several islands and on two major soil types. In this paper I use molecular phylogenies to understand the historical biogeographical patterns of this taxon both across the Caribbean Islands (i.e., within the Lasiocroton alliance) and across the serpentinite archipelago of Cuba (i.e., within Leucocroton).

\section{MATERIALS AND METHODS}

\section{Taxon Sampling}

A total of 37 individual collections were sampled from 28 recognized species (Table 1). The most distant outgroup was Philyra brasiliensis. This monospecific genus has been shown to represent the earliest diverging lineage of the tribe (Wurdack et al., 2005; Jestrow et al., 2008). The outgroup also included three species of Adelia, the sister genus to the Leucocroton-alliance. (De-Nova \& Sosa, 2007). Two of these species, A. ricinella and A. vaseyi represent the two primary clades of the genus (De-Nova \& Sosa, 2007). The third one, A. cinerea is a distinctive species of uncertain phylogenetic placement. De-Nova \& Sosa (2007) found this taxon to be the earliest diverging lineage of Adelia, while other studies place A. cinerea as sister to the Leucocroton alliance (De-Nova \& Sosa., 2007; Jestrow et al., in press).

The ingroup consisted of representatives from the Leucocroton alliance. It included five of the seven known species of Lasiocroton (Jestrow et al., 2008, in press) (Table 1). 
Lasiocroton gracilis Britton \& P.Wilson was not part of my study. This extremely rare taxon is known from a single collection dating from 1910, possibly representing a rare hybrid of $L$. bahamensis and L. microphyllus (see Discussion below). The other omitted species is the recently described L. gutierrezii Jestrow; this taxon is known from only two collections dating from 1949 and 1956, and is closely related to L. microphyllus (Jestrow et al., in press); however, during my field studies in Cuba, I was unable to find this species. I included two accessions from different localities of L. bahamensis, L. harrisii, and L. microphyllus (see Table 1.)

Formerly, Leucocroton was divided into three sections (Borhidi, 1991): Adeliocroton Borhidi (2 spp.), Lasiocrotonopsis Borhidi (7 spp.), and Leucocroton Borhidi (19 spp.). The two species belonging to section Adeliocroton are no longer included in the genus because one has been moved to Lasiocroton as L. microphyllus, and the other has been transferred to Garciadelia as G. leprosa (Willd.) Jestrow \& Francisco Rodr. Sixteen of the 26 species of Leucocroton were selected to represent its morphological variability and geographical distribution. Thirteen of them belonged to the section Leucocroton and three to the section Lasiocrotonopsis (i.e., L. moncadae, L. subpeltatus, L. virens) as described by Borhidi (1991). I included the type of the genus, L. wrightii (Webster, 1994; Radcliffe-Smith, 2001). The ten species of Leucocroton that were not included in this study have a limited collection history with poorly known geographical distributions and few collection localities. On the basis of my taxonomic studies, minor morphological characters distinguish these enigmatic species from those included in the present study. For example, L. longibracteatus Borhidi, a taxon morphologically similar to L. wrightii, was described on the basis of a single collection from Taco Bay of the Moa-Baracoa massif dating from 1952. I traveled to this 
locality and were unable to find a single exemplar of this species. When examining herbarium collections, I did not find additional localities for this taxon, nor any specimens collected after the type material. In spite of these difficulties in collecting these poorly known taxa of Leucocroton, I have included all species occurring in Western and Central Cuba. In Eastern Cuba, I have collected the two species from the Holguín massif (L. anomalus and L. virens). I am missing only nine enigmatic taxa (L. acunae, L. brittonii, L. cordifolius, L. discolor, L. incrustatus, L. longibracteosus, L. moaensis, L. obovatus, and L. pallidus) from the species-rich massifs of Mayarí-Cristal and Moa-Baracoa (Fig. 2). For a few of the taxa, I was unable to collect samples for every massif where they have been reported. For example, while L. moncadae is recorded for three different massifs, this taxon is presently known from a single population of the Habana-Matanza massif. I have included multiple collections of four taxa (i.e., L. comosus, L. ekmanii, L. linearifolius, and L. pachyphyllus), as I was able to find these species from different localities.

As for the recently described genus Garciadelia (formerly in Leucocroton section Adeliocroton), I included three species (i.e., G. abbottii, G. castilloae, and G. mejiae). Unfortunately, I did not study the Haitian endemic G. leprosa (Willd.) Jestrow \& Jiménez Rodr. because I was unable to obtain samples of this extremely rare species, last collected in 1924 (Jestrow et al., in press).

\section{DNA extraction, amplification, and sequencing}

Plant DNA was extracted from silica-dried material using a DNeasy Plant Mini Kit (Qiagen, Valencia, California). I used PuReTaq Ready-To-Go PCR Beads (GE Healthcare Life Sciences, Piscataway, New Jersey) for the PCR amplification reaction mix. For all regions, 
the cycle program used was as follows: (1) $80^{\circ} \mathrm{C}$ for $5 \mathrm{~min}$; (2) $94^{\circ} \mathrm{C}$ for $1 \mathrm{~min}$; (3) $50^{\circ} \mathrm{C}$ for $1 \mathrm{~min}$; (4) $72^{\circ} \mathrm{C}$ for $2 \mathrm{~min}$; 35 cycles from step (2); and (7) $72^{\circ} \mathrm{C}$ for $5 \mathrm{~min}$. The chloroplast DNA (cpDNA) noncoding regions, $p s b M-t r n D$ and $y c f 6-p c b M$ were amplified with primers previously published by Shaw et al. (2005). The ITS1, 5.8s, and ITS2 of the nuclear ribosomal DNA were amplified as one region using primers ITS 5 (Downie \& Katz-Downie, 1996) and ITS 4 (White et al., 1990). For members of Garciadelia and the species Leucocroton subpeltatus, the total ITS regions were cloned prior to sequencing. Cloning was required because of the poor quality of sequences obtained after direct sequencing (see Results below) for these particular taxa only. I used TOPO TACloning (Invitrogen, Carlsbad, California), following the manufacturer's guidelines. Cycle sequencing was performed in both directions with the PRISM BigDye v.3.1 Terminator Cycle Sequencing Kit (Applied Biosystems, Foster City, California) following the manufacturers instructions. The primers used for PCR amplification were also utilized for the cycle sequencing reactions. Nucleotide sequences were visualized on a PRISM 377 Automated DNA Sequencer (Applied Biosystems, Foster City, California) at the Florida International University (FIU) DNA Core Facility. All new sequence data were submitted to GenBank (see Table 1).

\section{Phylogenetic analysis}

All sequences were assembled and visually aligned, using Sequencher 3.1.1 (Gene Codes Corporation, Ann Arbor, Michigan). A single region in the $y c f 6-p c b M$ alignment was removed because of a large " $T$ " repeat (30-40 bp) in both the ingroups and outgroups, which could lead to slippage of the DNA polymerase. All regions were gap-coded using the Simple Indel Coding method (Simmons \& Ochoterena, 2000). 
When analyzing the ITS and the ITS-cpDNA combined data sets, the parsimony analyses were conducted as a two-step heuristic search in PAUP*4.0b10 (Swofford, 2003). First, trees were found using a 10,000 replicate heuristic search, saving no more than ten trees per replicate with Multrees off. The second step used the trees previously saved as the starting trees for another heuristic search with Multrees on.

The chloroplast data were run similarly, but as a result of the large number of seed trees, Multrees was not engaged for the second step. I conducted three analyses of the chloroplast data set; (1) $p s b M-t r n D$, (2) ycf6-pcbM, and (3) the combined two regions. Branch lengths for the total combined dataset were calculated according to the Deltran algorithm. Clade support was assessed with bootstrap analysis (Felsenstein, 1985) and searches were conducted using a 10,000 replicate heuristic approach with starting trees from random addition. The consistency index excluding uninformative characters $(\mathrm{CI})$, retention index (RI), and rescaled consistency index (RC) were also calculated (Kluge and Farris, 1969; Farris, 1989). Incongruence Length Difference (ILD) tests were run between the three major data sets (ITS, $p s b M-t r n D$, and $y c f 6-p c b M$ ).

Bayesian methods were also used for phylogenetic inferences in order to identify possible long branch attraction. However with the Bayesian analyses, I did not include gapcoding data given the uncertainties regarding molecular evolution modeling. Each region (ITS1, 5.8s, ITS2, psbM-trnD, ycf6-pcbM) was run separately through Modeltest v.3.06 (Posada \& Crandall, 1998). Models were chosen on the basis of the Akaike Information Criterion (AIC) following Posada and Crandall (1998). I used the following models for the Bayesian analyses: ITS 1, GTR+G; 5.8s, K80; ITS2, TIM+G; psbM-trnD, TIM+I; and ycf6pcbM, K81uf+I. Bayesian inferences were conducted using MrBayes 3.1.2 (Huelsenbeck \& 
Ronquist, 2001) with two Markov chain Monte Carlo (MCMC) runs of four linked chains for 1,000,000 generations sampling every 100 generations. The four chains included one cold, and the other three with incremental heating as per the default of MrBayes. Of the 10,001 trees produced per MCMC run, the first $25 \%$ of these trees were removed as burnin, resulting in a total of 15,000 trees. The burnin of $25 \%$ was determined to be adequate from the likelihood values, as the values leveled off at between 100,000 and 200,000 generations for the datasets. All Bayesian analyses produced split frequencies of less than 0.02 , showing convergence between the paired runs. I then used PAUP* to compute the majority consensus tree for the total data to give the posterior probabilities.

\section{Ancestral analysis}

For the ancestral area analyses, the members of the Leucocroton alliance were placed into six areas: (1) Western Cuba, (2) Central Cuba, (3) Eastern Cuba, (4) the Bahamas, (5) Jamaica, and (6) Hispaniola. The division of Western and Central Cuba was drawn between the two massifs, Havana-Matanza and Villa Clara, while Central and Eastern Cuba were separated between the Camagüey and Holguín massifs (Fig. 2). Three of the outgroup taxa do not occur on the Caribbean Islands, therefore they were assigned to either Central or South America. The exception was Adelia ricinella as this taxon is present in Cuba, Hispaniola, Jamaica, and South America.

Ancestral area analyses were conducted via two different methods: a cladistic approach described by Bremer (1992) and the dispersal-vicariance (DIVA) procedure of Ronquist (1997a). Both methods were applied to area and soil types using both Bayesian and parsimony tree topologies based on the ITS-cpDNA combined dataset. As both methods 
require fully bifurcating topologies, I randomly selected four fully resolved trees from both the parsimony and Bayesian methods as the basis to perform Bremer and DIVA ancestral areas reconstructions. As the cladistic method of Bremer can be calculated only for a particular node in a phylogeny, I chose two nodes to analyze my data. The first one was the basal node of the Leucocroton alliance (see Results below) and the second was the node defining the Lasiocroton clade (see Results below). As the parsimony and Bayesian topologies conflicted (see below), I calculated the Bremer values for these two nodes along both topologies. Ronquist's approach was implemented with the program DIVA 1.1 (Ronquist, 1997b) using the same topologies that were utilized for Bremer's cladistic method.

\section{RESULTS}

\section{ITS analysis}

The aligned ITS data matrix was 678 nucleotide positions in length and included 135 parsimony informative (PI) nucleotide positions along with 15 coded gaps, ten of which were PI (Table 2). Of these, 109 nucleotides and five coded gaps were PI within the Leucocroton alliance. The cladistic analysis yielded 5880 most parsimonious trees. The strict consensus tree shows Adelia cinerea to be sister to the Leucocroton alliance, with bootstrap support of 91\% (Fig. 4a). Within the Leucocroton alliance, the Hispaniolan genus Garciadelia was found to be sister to a clade formed by Lasiocroton and the Cuban genus Leucocroton, with bootstrap support of $87 \%$. The monophyly of the three genera of the Leucocroton alliance was strongly supported with bootstrap values exceeding 99\%. Within Leucocroton, Leucocroton section Lasiocrotonopsis (i.e., L. moncadae, L. subpeltatus, and L. virens) was 
found to be paraphyletic. The Jamaican endemic Lasiocroton macrophyllus formed a clade with $L$. bahamensis, with bootstrap value equal to $89 \%$. The Bayesian analysis produced a tree without any conflict to the parsimony strict consensus tree. Bayesian posterior probabilities for the monophyly of each genus were $100 \%$. The Bayesian posterior probabilities were higher than the bootstrap values for all clades, except for a single node that had the lowest bootstrap value of the phylogeny (60\%) (see asterisk, Fig. 4a).

The ITS regions of Garciadelia abbottii, G. castilloae, G. mejiae, and Leucocroton subpeltatus were cloned because of difficulties with direct sequencing. I blasted the cloned sequences of these four species through GenBank and found that some matched ITS accessions of endophytic Ascomycetes, which explains my difficulties in obtaining readable ITS sequences from direct PCR products. The fungal clones from the Garciadelia species were quite similar to each other, while the fungal clone from L. subpeltatus was significantly different. My initial GenBank searches showed that most of the cloned sequences matched ITS accessions of the Leucocroton alliance. I was able to recover five ITS clone sequences for each of these five taxa. Within each species, the five cloned sequences were extremely similar (Jestrow et al. in press), and, therefore, for my phylogenetic analyses I decided to include one representative clone per taxon. I chose the clones based on the minimum number of autapomorphic characters, thus allowing us to avoid false inflation of the branch lengths.

\section{Chloroplast analyses}

The aligned $p s b M-t r n D$ and $y c f 6-p s b M$ data matrices were 1070 and 1204 nucleotide positions in length, respectively (Table 2). The data set of psbM-trnD included 23 PI nucleotide positions along with 14 PI coded gaps. The $y c f 6-p s b M$ data matrix had 35 PI 
nucleotide positions and 13 PI coded gaps. Within the Leucocroton alliance, the psbM-trnD data set yielded 12 PI nucleotide positions with ten PI coded gaps. The $y c f 6-p s b M$ alignment had 27 PI nucleotide positions and ten PI coded gaps. The ILD test identified incongruence between the two chloroplast data sets $(\mathrm{p}=0.01)$. The $y c f 6-p s b M$ tree conflicted with the $p s b M$ trnD topology by nesting the outgroup taxon Philyra within the Adelia clade. The incongruence was resolved when this species was removed $(\mathrm{p}=0.47)$. The inclusion or exclusion of P. brasiliensis did not change the topology of the ingroup. The combined chloroplast cladistic analyses yielded 6646 most parsimonious trees.

In contrast to the results produced by the analyses of the ITS data, the combined chloroplast phylogeny found the Leucocroton clade poorly supported with a bootstrap value of only $56 \%$. However, the Garciadelia and Lasiocroton clades received strong support, with bootstrap values of $100 \%$ and $99 \%$, respectively. Within Leucocroton, resolution of the species relationships was weak. Only three clades were recovered within the genus, receiving bootstrap values below $55 \%$.

The main differences between the ITS and cpDNA topologies concerned the placement of Lasiocroton macrophyllus. The chloroplast phylogeny placed this taxon within a clade formed exclusively of taxa endemic to Jamaica (Fig. 4b). The Jamaican assemblage was weakly supported by a $63 \%$ bootstrap, although it received a higher support from the Bayesian analyses (see below).

Bayesian and parsimony analyses conflicted in the position of a single taxon, Leucocroton comosus. The Bayesian analysis placed (78\% posteriori probability) this Eastern Cuban species as sister to another species from that region of the island, L. saxicola. In contrast, the cladistic analyses weakly supported (54\% bootstrap value) a sister relationship 
between L. comosus and L. moncadae; the latter is restricted to the Central and Western Cuba. Interestingly, the clade of Lasiocroton species endemic to Jamaica received a stronger support from the Bayesian analyses (100\% a posteriory probability), but had a low bootstrap value of $63 \%$ after the parsimony analyses.

\section{Combined analysis}

The ILD tests showed conflicts between the ITS with both $p s b M-t r n D$ and $y c f 6-p s b M$ regions ( $\mathrm{P}=0.01)$. After removing Philyra brasiliensis and Lasiocroton macrophyllus, the conflict between the ITS and chloroplast regions remained. I analyzed the ITS-cpDNA combined data in spite of this incongruence, in order both to include the largest sample of informative characters and to compare the combined with the separate nuclear and chloroplast datasets. I followed the strategy of Wiens (1998) by including both the combined and separate ITS and cpDNA datasets, and discuss the differences and similarities found among them.

The parsimony analyses of the ITS-cpDNA combined data set confirmed the monophyly of the genera endemic to Cuba (Leucocroton, $100 \%$ bootstrap value) and Hispaniola (Garciadelia, 100\% bootstrap value). The species of the third genus of the alliance, Lasiocroton, also formed a monophyletic group supported by a bootstrap value of 99\%. This cladistic analysis found Adelia cinerea of Northern Mexico to be sister to the Leucocroton alliance, a relationship that was supported with a $100 \%$ bootstrap value.

The ITS and the ITS-cpDNA combined data sets had similar phylogenies, and they both recovered the same major clades within each of the three genera. Two major clades were found within Leucocroton. The first one had the two accessions of the Eastern Cuba endemic, L. pachyphyllus. The second clade received a $73 \%$ bootstrap support and had the 
remaining 15 taxa of the genus. This second clade had three lineages that collapsed in a polytomy. The first lineage had a single species, L. subpeltatus of Eastern Cuba. The second lineage had 12 species, ten of them are restricted to Eastern Cuba and they formed a monophyletic group strongly supported with a $94 \%$ bootstrap value. The remaining two taxa of this lineage formed another monophyletic group ( $80 \%$ bootstrap value). One of these taxa is restricted to Western Cuba (i.e., L. flavicans) whereas the second one (i.e., L. virens) has a widespread distribution on serpentine areas of Central and Western Cuba. The third lineage was weakly supported with a $53 \%$ bootstrap value and had seven species. Three of them (i.e., L. havanensis, L. moncadae, and L. revolutus) are from Western and/or Central Cuba and formed a strongly supported clade with a $100 \%$ bootstrap value. The remaining four species are Eastern Cuban endemics, but only three of them formed a monophyletic group (i.e., $L$. anomalus, L. stenophyllus, and L. saxicola) that was supported with a $99 \%$ bootstrap value. The fourth, L. linearifolius, was the earliest divergent branch of the third lineage.

Lasiocroton was composed of two major clades. The first one had the two accessions of the Cuban endemic L. microphyllus. The second clade was supported with a bootstrap value of $100 \%$ and had two lineages. The first one comprised the two Jamaican endemics $L$. fawcettii and L. harrisii (bootstrap support of 95\%). The second lineage had the other two species of this genus, L. bahamensis (a species with a widespread distribution in the Bahamas, Cuba, and Hispaniola) and L. macrophyllus (endemic in Jamaica). However, a sister relationship between these two taxa was weakly supported with a $68 \%$ bootstrap value.

The two species of Garciadelia from Southern Hispaniola formed a monophyletic group (supported with a $96 \%$ bootstrap value) that was sister to G. abbottii, an endemic in the Northeastern part of the island (Fig. 3d). 
The topologies from parsimony and Bayesian methods conflicted within the genus Leucocroton at three nodes, but these nodes lacked support ( $<50 \%$ bootstrap value). The only other conflict between the parsimony and Bayesian reconstructions concerned Lasiocroton macrophyllus. The Bayesian topology (51\% clade credibility) grouped this taxon as sister to the Jamaican species, but the parsimony topology placed this species with L. bahamensis ( $68 \%$ bootstrap value).

\section{Ancestral area analysis}

For the Leucocroton-alliance node, the cladistic method (Bremer, 1992) strongly favored Eastern Cuba (1.00 AA value) as the ancestral area in both parsimony and Bayesian topologies (Table 3 ). This method yielded Hispaniola as a second choice $(0.38)$ for the Bayesian topology, while the parsimony reconstruction found Hispaniola, Jamaica and Western Cuba as second in importance (0.36). I found that these cladistic historical biogeography reconstructions were sensitive to the distribution scoring of a single species, Lasiocroton bahamensis, known from Hispaniola by a single collection from Haiti (see Discussion below). The omission of "Hispaniola" from the distribution scoring of $L$. bahamensis significantly increases the statistics for Hispaniola as an ancestral area for the alliance for both parsimony (0.50) and Bayesian reconstructions (0.57), though Cuba was still the first choice (1.00) (see asterisks Table 3).

For the Lasiocroton clade, Bremer's method yielded different results along the Bayesian and parsimony topologies (Table 4). The parsimony tree supported the three areas of Cuba and Jamaica as equally likely ancestral areas (1.00) for the genus. In contrast, reconstruction along the Bayesian tree found the three areas of Cuba as the ancestral area 
(1.00). Removal of "Hispaniola" from the distribution scoring of L. bahamensis did not change the results of the cladistic method for the Lasiocroton clade, as L. bahamensis was the only member of the clade to occur on the island.

Dispersal-vicariance analysis produced similar results to Bremer's method. For the Leucocroton-alliance, DIVA shows Eastern Cuba and Hispaniola as the ancestral area, according to both parsimony and Bayesian trees (Fig. 6). Furthermore, both topologies found the ancestral area of Garciadelia to be Hispaniola and of Leucocroton to be Eastern Cuba. The only discrepancies between the two topologies in the DIVA analysis are found within the Lasiocroton clade. Based on the parsimony reconstruction, Eastern Cuba or Eastern Cuba Jamaica are the ancestral areas for this genus. In contrast, DIVA selected only Eastern Cuba as the ancestral area along the Bayesian tree. Interestingly, within the Lasiocroton clade, the Bayesian topology produced an output with fewer ancestral areas than the parsimony topology as it identified the Jamaican taxa as a monophyletic group (Fig. 6).

Unlike the Bremer reconstruction which was sensitive to the scoring of Lasiocrton bahamensis, DIVA was resilient and consistent. The DIVA analysis, when including Hispaniola in the scored distribution of L. bahamensis, produced a single change with the parsimony topology. This subtlety is seen as the inclusion of Hispaniola as one of many ancestral areas for the L. bahamensis clade (Fig. 6).

Concerning Leucocroton, DIVA yielded identical results both along the Bayesian and parsimony topologies. Eastern Cuba is the ancestral area for the genus. Indeed, most of the clades have this region as an ancestral area, with two exceptions: (1) the assemblage of $L$. flavicans and L. virens had the three areas of Cuba as a potential ancestral area; and (2) the clade of $L$. havanensis, L. moncadae, and L. revolutus had Western Cuba as its ancestral area. 


\section{DISCUSSION}

\section{Biogeographical patterns across islands and soils}

All of the analyses agreed that the ancestral forms of the Leucocroton alliance originated in Eastern Cuba and/or Hispaniola. These two regions are geographically close $(75 \mathrm{~km}$ between Cajobabo in Eastern Cuba and Môle St. Nicolas in Haiti), and they formed a single geographical unit until the early Miocene ( 16 Ma) when they started to separate through tectonic processes (Iturralde-Vinent, 2006; Pindell et al., 2006; Pindell \& Kennan, 2009).

The earliest split of the alliance yielded two major groups, one of them restricted to limestone regions of Hispaniola (i.e., Garciadelia clade) with only four species. Ancestral forms of this group originated on this island. Notably, none of the species of this genus colonized the available serpentine areas of Hispaniola (i.e., Loma Caribe and North Coast Belt, Fig. 3d). The second speciation group comprised two clades. The members of the first of these clades, Lasiocroton, successfully colonized limestone areas of Cuba (three endemic species) and Jamaica (three endemic species), with L. bahamensis reaching the Bahamas, Cuba, and Hispaniola (a single and uncertain record, see below). None of the members of this clade have colonized serpentine regions. My historical biogeography reconstructions primarily supported Eastern Cuba as the ancestral area for the Lasiocrotron clade.

The second clade (i.e., Leucocroton), although limited to the serpentine areas of Cuba, has the highest number of species (26 spp.) and provides the most extensive example of speciation within the alliance. None of the species of this clade thrive on the limestone areas of Cuba. Ancestral area reconstructions identified Eastern Cuba as the region where this genus originated. 
A study of ancestral soil types using Bremmer's method and DIVA (data not presented) showed that limestone areas represent the ancestral soil type for the alliance. Several molecular phylogenies have included West Indian endemics that are restricted to serpentine soils (e.g., McDowell \& Bremer, 1998, McDowell et al., 2003; Lavin et al., 2001; Loockerman et al., 2003; Liu et al., 2004; Namoff et al., 2007; Pelser et al., 2007; Cariaga et al., 2008; Francisco-Ortega et al., 2008; Michelangeli et al., 2008, pers. comm.; van Ee et al., 2008; Rova, 2009). However, most of these studies focus on plant systematics and rarely discuss speciation events and soil adaptation in a historical biogeographical context. An exception was provided by Liu et al. (2004) who reported forms from serpentine soils of Cuba as ancestral types to the Sachsia Griseb. Rhodogeron Griseb. group (Asteraceae). These authors indicated that the evolutionary history of these genera has followed a colonization track from serpentine to limestone areas. My results indicate a different evolutionary pathway for the Leucocroton alliance, and concurs with Borhidi (1996) who suggested that plant colonization in Cuba has occurred from non-serpentine areas towards those with ultramafic soils. This direction of colonization is also supported by results for the Neotropical genus Exostema (Pers.) Bonpl. (Rubiaceae) (MacDowell \& Bramwell, 1998; MacDowell et al., 2003), which showed that the five serpentine species endemic to Cuba and Hispaniola not only had three independent origins but also were part of the terminal branches of the phylogeny of the genus.

My results support a single origin for the serpentine species of Leucocroton. A similar pattern has been reported for endemics of Croton L. subgenus Moacroton (Croizat) van Ee \& P.E. Berry (van Ee et al., 2008). However, multiple origins for 
serpentine endemics have also been found not only within Exostema (see above), but within the "Caribbean clade" of the tribe Miconieae (Melastomataceae) (Michelangeli et al., 2008, pers. comm.).

I included multiple collections for each of seven species of the Leucocroton alliance. For five of them, these multiple accessions formed distinct monophyletic groups, therefore my phylogeny supports them being distinct taxa that have differentiated from the rest of the members of the alliance. In contrast, the multiple accessions of $L$. cosmosus and of L. ekmanii did not form two distinct monophyletic groups. However, phylogenetic relationships within these collections and their sister taxa received low statistical support and therefore it is premature to draw conclusions concerning the phylogenetic placement of these accessions and the monophyly of these two species.

\section{Leucocroton and the serpentine islands of Cuba}

Leucocroton arose in Eastern Cuba on the large ultramafic massifs. The lateritic soils derived from these massifs date between 10-30 million years aga (Ma), and are about the same age as the small serpentine area of Western Cuba, at Cajálbana (Finko et al., 1967; Borhidi, 1996; Lewis et al., 2006). The serpentine areas between these extremities are ca. 1 Ma (Finko et al., 1967; Borhidi, 1996). Paleogeographical studies suggested that Eastern and Western Cuba were two separate islands until approximately 6 Ma when a land-bridge was established between them (Iturralde-Vinent, 2006). Groups with this biogeographical disjunction have been identified in the tribe Tageteae (Asteraceae) (i.e., Lescaillea Griseb. and Harnackia Urb.), Heptanthus Griseb. (Asteraceae), Spathelia L. (Rutaceae), and Purdiaea Planch. (Cyrillaceae) (reviewed by Bordács \& Borhidi, 1993; 
Borhidi, 1996). My molecular phylogenies do not detect two clades supporting a strict Eastern-Western Cuba split. The biogeographical situation of Leucocroton follows a more complex pattern. All taxa restricted to a particular area do not group in a single separate clade. For instance, the nine species from Eastern Cuba belong to three different monophyletic groups. Likewise the two species confined to Western Cuba belong to two different clades. These results suggest that the genus has undergone multiple introductions to each of the "islands" that form the serpentine archipelago of Cuba.

Although, some of the nodes within the Leucocroton clade have low statistical support, it appears that at least two migrations across the island occurred in the evolutionary history of this genus. The first one was supported with a $88 \%$ a posteriori probability and included three species from Eastern Cuba (i.e., L. anomalus, L. saxicola, and L. stenophyllus) and three from Western and/or Central Cuba (i.e., L. havanensis, L. moncadae, and L. revolutus). Historical biogeographical analyses identified EasternWestern Cuba as the ancestral area for this assemblage. The second migration group received a $99 \%$ posteriori probability and included five species from the Eastern portion of the island, one from Central-Eastern Cuba, and one restricted to Western Cuba. This group had Eastern Cuba as an ancestral area.

The historical biogeographical study suggested Eastern Cuba as the major center of diversification of Leucocroton species and supported a general east to west migration route. Interestingly, Borhidi (1996) in his seminal work on Cuban phytogeography indicated that Eastern Cuba is the "starting point for the most important migrations" on the island. My results appear to confirm this hypothesis. 


\section{Conflicting topologies: biogeographical implications}

Within the Leucocroton alliance, the placement of the Jamaican endemic Lasiocroton macrophyllus is the primary culprit of the main topological conflicts between the nuclear and chloroplast phylogenies. The ITS topology placed this species as sister to the widespread L. bahamensis. In contrast, the cpDNA data supported this taxon as part of a clade composed exclusively of Jamaican endemics. Likewise, the parsimony and Bayesian analyses of the combined data set did not agree about the placement of this taxon. The former supported L. macrophyllus as sister to L. bahamensis (bootstrap support of 68\%), whereas the Bayesian analyses placed this taxon within the Jamaican clade with a low a posteriori probability of $51 \%$.

Both lineage sorting between the nuclear and chloroplast regions and/or hybridization could explain this conflict. Lasiocroton bahamensis does not reach Jamaica, and although I cannot rule out that this species occurred on the island in the past, the available evidence suggests that hybridization is not the best explanation for the conflicting placement of L. macrophyllus. Morphologically this species is very similar to L. bahamensis, with only subtleties of branching habit, leaf apex, and stigma structure differentiating them. Lasiocroton bahamensis was initially identified as L. macrophyllus (Northrop, 1902) before being formally described as a distinct species (Pax \& K. Hoffm., 1914). In addition, both species occur on coastal limestone. I believe that L. macrophyllus evolved in the lowlands of Jamaica as a transitional form between L. bahamensis and the two other Jamaican endemics. These two other taxa are confined to montane environments of this island (Fig. 3c). Therefore, I hypothesize that lineage sorting 
between the nuclear and chloroplast markers, rather than hybridization, provides the best explanation for the conflictive phylogenetic placement of L. macrophyllus.

Because of the conflict concerning the placement of Lasiocroton macrophyllus, reconstruction of ancestral areas for the Lasiocroton clade using DIVA yielded different results along the Bayesian and parsimony topologies (Fig. 6). However, I favor the results along the Bayesian phylogeny, as this reconstruction agrees with my hypothesis of $L$. macrophyllus as a taxon with its ancestor in Jamaica (see above). In contrast, results along the parsimony topology yielded five putative ancestral areas for the ancestor of $L$. macrophyllus.

In my study I am not arguing that hybridization has not been relevant in the evolutionary history of the Leucocroton alliance. A good example of its importance is provided by the Cuban endemic Lasiocroton gracilis. Known from a single collection from southern Cuba in 1902, this taxon exhibits intermediate characters of L. bahamensis and the Cuban endemic L. microphyllus. I suggest that the best interpretation of $L$. gracilis is that it arose from a rare hybrid between these two morphologically-distinct species (Jestrow, in preparation). Unfortunately, during my field trips to Eastern Cuba I was unsuccessful in trying to locate plants of this putative hybrid species.

\section{Lasiocroton bahamensis: the biogeography of a widespread species}

Lasiocroton bahamensis is unique as it is the only species in the Leucocroton alliance to occur on more than one island. While originating in Eastern Cuba (Fig. 6), the species has dispersed to the Bahamas and the northeastern tip of Hispaniola. Within the Bahamas it has been collected from four islands: Eleuthera, Great Ragged Island, Great Exuma, and 
South Andros (Fig. 3b). These four Bahamian islands are part of the Great Bahama Bank which formed a large landmass during the last glacial maximum, approximately 18,000 yr BP (Hearty \& Kaufman, 2000). This ancient land mass was separated from Cuba by only ca. 20 kilometers and had approximately the same area of current Hispaniola. While L. bahamensis dispersed to the Bahamas, the other coastal limestone species of Cuba, $L$. microphyllus, is only found on Cuba. One difference between these two coastal limestone species is fruit production. Plants of Lasiocrotom bahamensis produce copious amounts of fruit per inflorescence and they are held high in the trees. In contrast, L. microphyllus has only 1-3 fruits and they are typically held near the ground. This morphological difference suggests a more limited ability for dispersal by L. microphyllus and may help explain why L. bahamensis has migrated across the narrow strait between Cuba and the Bahamas. However, the distribution of L. bahamensis on Hispaniola raises other questions. The single collection of the species on the island was made by the great plant collector Erik Ekman in 1925 (located at S) near "Môle St. Nicholas." Ekman's notes for this specimen states “obs. only one poor individual found!" Ekman was familiar with the species, having collected broadly in Cuba, and clearly looked specifically for more plants of this species at the Haitian locality, without success. Môle St. Nicolas is a port on a bay and was a hub of commerce in the Caribbean from the late $15^{\text {th }}$ century until its eventual decline in the late 1800's (Barskett, 1818). The long history of commerce, combined with knowledge that only a single plant has ever been collected from this site, raises the question if this represents a record for a human-based introduction or for a truly native Hispaniolan species. 


\section{REFERENCES}

Abbott, R.N., Jackson, T.A. \& Scott, P.W. (1999) The serpentinization of peridotite from Cedar Valley, Jamaica. International Geology Review, 41, 836-844.

Andrus, N., Tye, A., Nesom, G., Bogler, D., Lewis, C., Noyes, R., Jaramillo, P. \& Francisco-Ortega, J. (2009). Phylogenetics of Darwiniothamnus (Asteraceae: Astereae) -Molecular evidence for multiple origins in the endemic flora of the Galápagos Islands. Journal of Biogeography, 36, 1055-1069.

Barskett, J. (1818) History of the Island of St. Domingo, from its first discovery by Columbus to the present period. Rest Fenner, London.

Bordács, M.M. \& Borhidi, A. (1993) Preliminary studies of possible Nihyperaccumulators in the serpentine flora of Cuba. II. Acta Botanica Hungarica, 38, 447-454.

Borhidi, A. (1991). Taxonomic revision of genus Leucocroton (Euphorbiaceae). Acta Botanica Hungarica, 36, 13-40.

Borhidi, A., Baker A.J.M., Zequeira, M.F. \& Prieto, R.O. (1992). Preliminary studies on the possible Ni-hyperaccumulator plants of Cuba. Acta Botanica Hungarica. 37, 279286.

Borhidi, A. (1996). Phytogeography and Vegetative Ecology of Cuba, Akademiai Kiado, Budapest.

Bremer, K. (1992) Ancestral areas: A cladistic reinterpretation of the center of origin concept. Systematic Biology. 41, 436-445.

Brooks, R.R. (1987) Serpentine and its vegetation: a multidisciplinary approach. Croom Helm, London.

Cariaga, K.A., Pruski, J.F., Oviedo, R., Anderberg, A.A., Lewis, C.E. \& FranciscoOrtega, J. (2008) Phylogeny and systematic position of Feddea (Asteraceae: Feddeeae): a taxonomically enigmatic and critically endangered genus endemic to Cuba. Systematic Botany. 33, 193-202.

Cecchi, L. \& Selvi, F. (2009) Phylogenetic relationships of the monotypic genera Halacsya and Paramoltkia and the origins of serpentine adaptation in circummediterranean Lithospermeae (Boraginaceae): insights from ITS and matK DNA sequences. Taxon, 58, 700-714.

De-Nova, J.A. \& Sosa, V. (2007) Phylogeny and generic delimitation of Adelia (Euphorbiaceae) inferred from molecular and morphological data. Taxon. 56, 10271036. 
Downie, S.R. \& Katz-Downie, D.S. (1996) A molecular phylogeny of Apiaceae subfamily Apioideae: evidence from nuclear ribosomal DNA internal transcribed spacer sequences. American Journal of Botany. 83, 234-251.

Draper, G. \& Barros, J.A. (1994) Cuba: in Donovan S.K. and Jackson, T. A. (eds.) Caribbean Geology: an introduction, University of the West Indies Publishers Association/University of the West Indies Press, Kingston, Jamaica, p. 65-86.

Draper, G. Guitierrez, G. \& Lewis, J.F. (1996) Thrust emplacement of the Hispaniola peridotite belt: orogenic expression of the mid Cretaceous Caribbean arc polarity reversal? Geology, 24, 1143-1146.

Eastwood, A., Gibby, M. \& Cronk, Q.C.B. (2004) Evolution of St. Helena arborescent Astereae (Asteraceae): relationships of the genera Commidendrum and Melanodendron. Botanical Journal of the Linnean Society, 144, 69-83.

Finko, V. I., Korin, I. Z., \& Formell, C. F. (1967) Sobre la edad de la corteza del intemperismo y las lateritas de Cuba. Revista Geológica. Academia de Ciencias de Cuba. 1, 29-47.

Farris, J.S. (1989) The retention index and homoplasy excess. Systematic Zoology. 38, 406-407.

Felsenstein, J. (1985) Confidence limits of phylogenies: An approach using bootstrap. Evolution. 39, 783-791.

Francisco-Ortega, J., Jansen, R.K. \& Santos-Guerra, A. (1996) Chloroplast DNA evidence of colonization, adaptive radiation, and hybridization in the evolution of the Macaronesian flora. Proceedings of the National Academy of Sciences of the United States of America, 93, 408-4090.

Francisco-Ortega, J., Santiago-Valentin, E., Acevedo-Rodriguez, P., Lewis, C., Pipoly, J., Meerow, A.W., Maunder, M. (2007) Seed plant genera endemic to the Caribbean island Biodiversity hotspot: A review and a molecular phylogenetic perspective. Botanical Review, 73, 183-234

Francisco-Ortega, J., Ventosa, I., Oviedo, R., Jimenez, F., Herrera, P., Maunder, M. \& Panero, J.L. (2008) Caribbean Island Asteraceae: Systematics, molecules, and conservation on a biodiversity hotspot. Botanical Review, 74, 112-131.

Friedman, J. \& Barrett S.C.H. (2009) Winds of change: new insights on the ecology and evolution of pollination and mating in wind-pollinated plants. Annals of Botany. 103, 1515-1527. 
Ghaderian, S.M., Mohtadi, A., Rahiminejad, R., Reeves, R.D. \& Baker, A.J.M. (2007) Hyperaccumulation of Nickel by two Alyssum species from the serpentine soils of Iran. Plant and Soil. 293, 91-97.

Hearty, P.J. \& Kaufman, D.S. (2000) Whole-rock aminostratigraphy and quarternary sealevel history of the Bahamas. Quarternary Research. 54, 163-173.

Huelsenbeck, J.P. \& Ronquist, F. (2001) MrBayes: Bayesian inference of phylogenetic trees. Bioinformatics. 17, 754-755.

Iturralde-Vinent, M.A. \& MacPhee, R.D.E. (1999) Paleogeography of the Caribbean region: implications for Cenozoic biogeography. Bulletin of the American Museum of Natural History, 238, 1-95.

Iturralde-Vinent, M.A. (2006) Meso-Cenozoic Caribbean paleogeography: implications for the historical biogeography of the region. International Geology Review, 48, 791827.

Jaffré, T. (1980) Etude Ecologique du Peuplement Végétal des Sols Dérivés de Roches Ultrabaiques en Nouvelle Calédonie. O.R.S.T.O.M., Paris.

Jestrow, B., Proctor, G. \& Francisco-Ortega, J. (2008) Lasiocroton trelawniensis (Euphorbiaceae), a critically endangered species from the Cockpit Country of Jamaica, belongs to Bernardia (Euphorbiaceae). Botanical Review, 74, 166-177.

Jestrow, B., Jiménez, F. \& Francisco-Ortega, J. (in press) Generic delimitation in the Antillean Adelieae (Euphorbiaceae) with the description of the Hispaniolan endemic genus Garciadelia. Taxon.

Kluge, A.G. \& Farris, J.S. (1969) Quantitative phyletics and the evolution of anurans. Systemtic Zoolology. 18, 1-32.

Lavin, M., Wojciechowski, M.F., Richman, A., Rotella, J., Sanderson, M.J. \& Matos, A.B. (2001) Identifying tertiary radiations of Fabaceae in the Greater Antilles: alternatives to cladistic vicariance analysis. International Journal of Plant Sciences. 162, S53-S76.

Lewis, J.F., Draper, G., Proenza, J.A., Espaillat, J. \& Jimenez, J., (2006) Ophioliterelated ultramafic rocks (serpentinites) in the Caribbean region: a review of their occurrence, composition, origin, emplacement and Ni-laterite soils formation. Geologica Acta. 4, 237-263.

Liu, H., Trusty, J., Oviedo, R., Anderberg, A. \& Francisco-Ortega, J. (2004) Molecular Phylogenetics of the Caribbean genera Rhodogeron and Sachsia (Asteraceae). International Journal of Plant Sciences. 165, 209-217. 
Loockerman, D.J., Turner, B.L. \& Jansen, R.K. (2003) Phylogenetic relationships within the Tageteae (Asteraceae) based on nuclear ribosomal ITS and chloroplast ndhF gene sequences. Systematic Botany. 28, 191-207.

McDowell, T. \& Bremer, B. (1998) Phylogeny, diversity, and distribution in Exostema (Rubiaceae): implications of morphological and molecular analyses. Plant Systematics and Evolution. 212, 215-246.

McDowell, T. Volvsek, M. \& Manos, P. (2003) Biogeography of Exostema (Rubiaceae) in the Caribbean region in light of molecular phylogenetic analyses. Systematic Botany. 28, 431-441.

Michelangeli, F.A., Judd, W.S., Penneys, D.S., Skean Jr., J.D., Bécquer-Granados, E.R., Goldenberg, R. \& Martin, C.V. (2008) Multiple events of dispersal and radiation of the tribe Miconieae (Melastomataceae). Botanical Review. 74, 53-77.

Namoff, S., Thorton, H.E.B., Lewis, C.E., Oviedo, R. \& Francisco-Ortega, J. (2007) Molecular evidence for phylogenetic relationships of Jacquemontia reclinata House (Convolvulaceae) - a critically endangered species from south Florida. Botanical Journal of the Linnean Society. 154, 443-454.

Nguyen, N.H., Driscoll, H.E. \& Specht, C.D. (2008) A molecular phylogeny of the wild onions (Allium; Alliaceae) with a focus on the western North American center of diversity. Molecular Phylogenetics and Evolution. 47, 1157-1172.

Northrop, A.R. (1902) Flora of New Providence and Andros, Memoirs of the Torrey Botanical Club. 12, 1-98.

Pax, F. \& Hoffman, K. (1914) Euphorbiaceae-Acalypheae-Mercurialinae. Pp. 1--473 in: A. Engler (ed.), Das Pflanzenreich. IV. 147. VII (63). Wilhelm Engelmann, Berlin.

Pelser, P.B., Nordenstam, B., Kadereit, J.W. \& Watson, L.E. (2007) An ITS phylogeny of tribe Senecioneae (Asteraceae) and a new delimitation of Senecio L. Taxon. 56, 10771104.

Pillon, Y., Munzinger, J., Amir, H., Hopkins, H.C.F. \& Chase, M.W. (2009a) Reticulate evolution on a mosaic of soils: diversification of the New Caledonian endemic genus Codia (Cunoniaceae). Molecular Ecology. 18, 2263-2275.

Pillon, Y., Hopkins, H.C.F., Munzinger, J., Amir, H. \& Chase, M.W. (2009b) Cryptic species, gene recombination and hybridization in the genus Spiraeanthemum (Cunoniaceae) from New Caledonia. Botanical Journal of the Linnean Society. 161, 137-152. 
Pillon, Y., Hopkins, H.C.F., Munzinger, J. \& Chase, M.W. (2009c) A molecular and morphological survey of the genetic limits of Acsmithia and Spiraeanthemum (Cunoniaceae). Systematic Botany. 34, 141-148.

Pindell, J., Kennan, L., Stanek, K.P., Maresch, W.V. \& Draper, G. (2006) Foundations of Gulf of Mexico and Carribean evolution: eight controversies resolved. Geologica Acta. 4, 303-341.

Pindell, J. \& Kennan, L. (2009) Tectonic evolution of the Gulf of Mexico, Caribbean and northern South America in the mantle reference frame: an update. Geological Society, London, Special Publications. 328, 1-55.

Posada, D. \& Crandall, K.A. (1998) Modeltest: Testing the model of DNA substitution. Bioinformatics. 14, 817-818.

Price, J.P. \& Wagner, W.L. (2004) Speciation in Hawaiian angiosperm lineages: cause, consequence, and mode. Evolution. 58, 2185-2200.

Radcliffe-Smith, A. (2001) Genera Euphorbiacearum. Royal Botanic Gardens, Kew.

Reeves, R.D., Baker, A.J.M., Borhidi, A. \& Berazain, R. (1996). Nickel-accumulating plants from the ancient serpentine soils of Cuba. New Phytologist. 133, 217-224.

Reeves, R.D., Baker, A.J.M., Borhidi, A. \& Berazain, R. (1999). Nickel Hyperaccumulation in the Serpentine Flora of Cuba. Annals of Botany. 83, 29-38.

Reeves, R.D., Baker, A.J.M., Becquer, T., Echevarria, G. \& Miranda, Z.J.G. (2007) The flora and biogeochemistry of the ultramafic soils of Goiás state, Brazil. Plant and Soil. 293, 107-119.

Révillon, S., Arndt, N.T., Chauvel, C. \& Hallot, E. (2000) Geochemical study of ultramafic volcanic and plutonic rocks from Gorgon island, Colombia: the plumbing system of an oceanic plateau. Journal of Petrology. 41, 1127-1153.

Ronquist, F. (1997) Dispersal-vicariance analysis: a new approach to the quantification of historical biogeography. Systematic Biology. 46, 195-203.

Rova, J.H.E., Delprete, P.G. \& Bremer, B. (2009) The Rondeletia complex (Rubiaceae): an attempt to use ITS, rps16, and trnl-f sequence data to delimit Guettardeae, Rondeletieae, and sections within Rondeletia. Annals of the Missouri Botanical Garden, 96, 182-193.

Shaw, J., Lickey, E.B., Beck, J.T., Farmer, S.B., Liu, W., Miller, J., Siripun, K.C., Winder, C.T., Schilling, E.E. \& Small, R.L. (2005) The tortoise and the hare II: Relative utility of 21 noncoding chloroplast DNA sequences for phylogenetic analysis. American Journal of Botany. 92, 142-166. 
Simmons, M.P. \& Ochoterena, H. (2000) Gaps as characters in sequence-based phylogenetic analyses. Systematic Biology. 49, 369-381.

Swofford, D.L. (2003) PAUP*: Phylogenetic analysis using parsimony (*and other methods). Version 4. Sinauer Associates, Sunderland, Massachusetts.

Trusty, J.L., Olmstead, R.G., Santos-Guerra, A., Sa-Fontinha, S. \& Francisco-Oretga, J. (2005) Molecular phylogenetics of the Macaronesian endemic genus Bystropogon (Lamiaceae): paleo-islands, ecological shifts, and inter-island colonizations. Molecular Ecology. 14, 1177-1189.

van Ee, B.W., Berry, P.E., Riina, R. \& Guitérrez, J.E. (2008) Molecular phylogenetics and biogeography of the Caribbean-centered Croton subgenus Moacroton (Euphorbiaceae s.s.). Botanical Review. 74, 132-165.

Verbruggen, N., Hermans, C. \& Schat, H. (2008) Molecular mechanisms of metal hyperaccumulation in plants. New Phytologist. 181, 759-776.

Voris, H.K. (2000) Maps of Pleistocene sea levels in Southeast Asia: Shorelines, river systems and time durations. Journal of Biogeography. 27,1153-1167.

Webster, G.L. (1994) Synopsis of the genera and suprageneric taxa of Euphorbiaceae. Annals of the Missouri Botanical Garden. 81, 33-144.

Wiens, J.J. (1998) Combining data sets with different phylogenetic histories. Systematic Biology. 47, 315-324.

White, T.J., Bruns, T., Lee, S. \& Taylor, J. (1990) Amplification and direct sequencing of fungal ribosomal RNA genes for phylogenetics. Pp. 315-322 in: Innis, M.A., Gelfand, D. H., Sninsky, J.J. \& White, T.J. (eds.), PCR protocols: A guide to methods and applications. Academic Press, San Diego, California.

Wurdack, K.J., Hoffmann, P. \& Chase, M.W. (2005) Molecular phylogenetic analysis of uniovulate Euphorbiaceae (Euphorbiaceae sensu stricto) using plastid rbcL and trnLF DNA sequences. American Journal of Botany. 92, 1397-1420. 
Figure 1 Photographs of staminate inflorescences in the left column and pistillate in the right of species of the Leucocroton alliance. (a) Garciadelia abbottii in Los Haitises, Dominican Republic (photograph by Brett Jestrow). (b) G. mejiae in Sierra de Bahoruco, Dominican Republic (photograph by Francisco Jiménez). (c) Lasiocroton microphyllus, living collections of the National Botanical Garden of Cuba (photograph by Benjamin van Ee). (d) L. bahamensis in coastal Guantánamo, Cuba (photograph by Benjamin van Ee). (e) Leucocroton pachyphyllus in Minas Iberia, Holguín, Cuba (photograph by Benjamin van Ee). (f) L. comosus Sierra del Nipe, Holguín, Cuba (photograph by Benjamin van Ee).
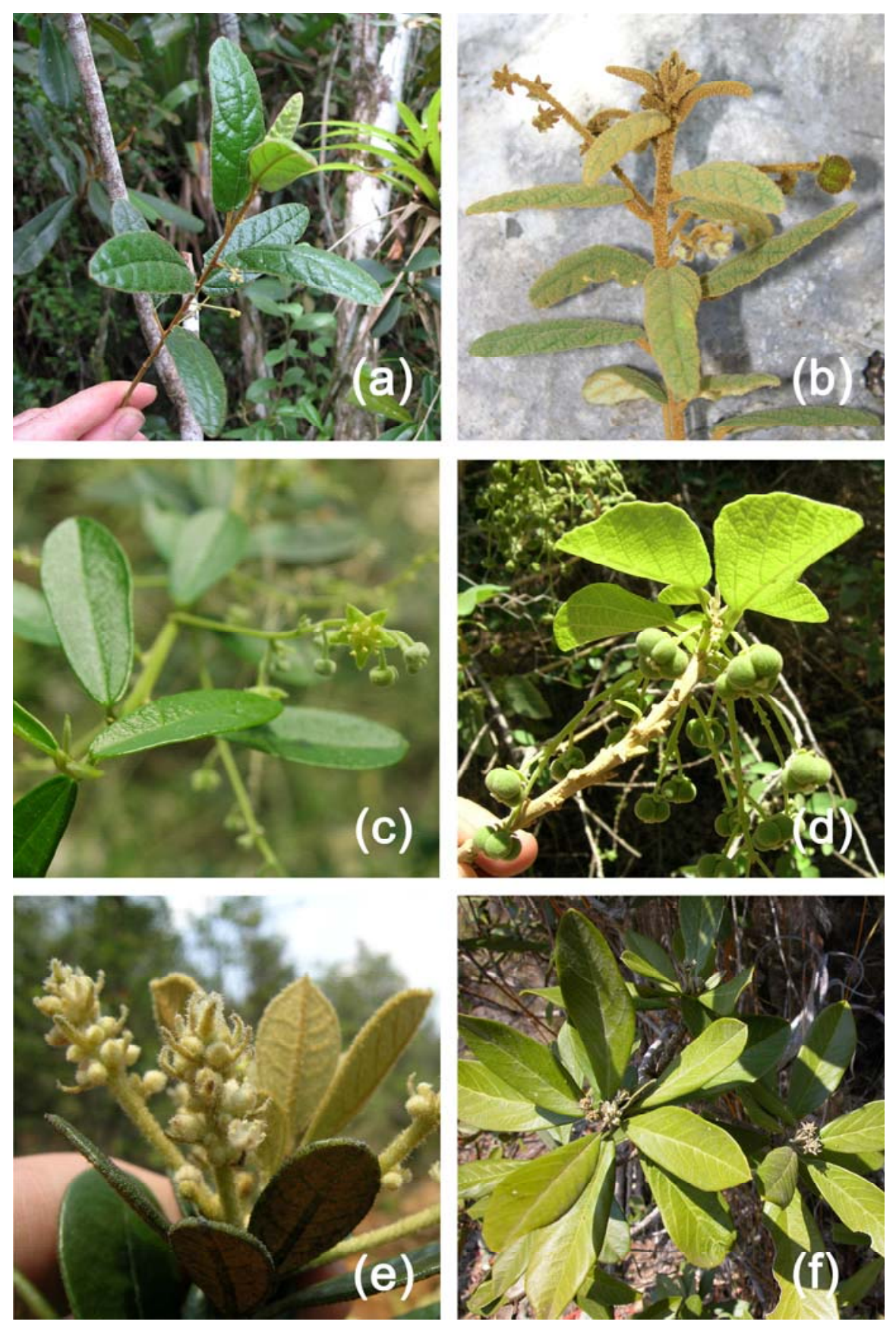
Figure 2 The nine major ultramafic massifs of Cuba showing the distribution of Leucocroton. A tenth small massif, Alto de la Corea, is not shown separate form the large Mayarí-Cristal massif which it borders. Species are listed for every massif where they have been recorded. Underlined species were not included in the molecular analyses. (adapted from Lewis et al., 2006 and Reeves et al., 1999).

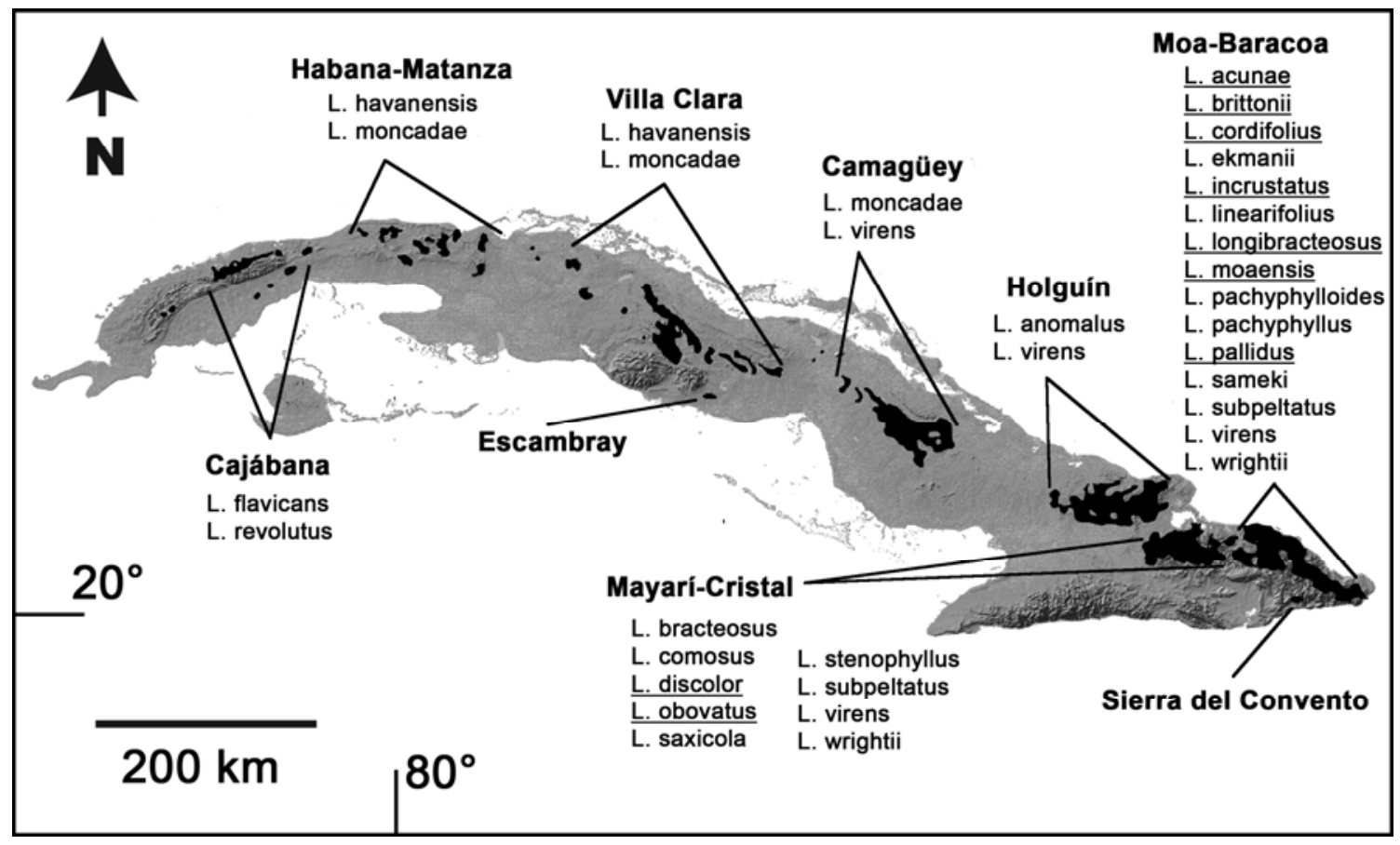


Figure 3 Geographical distribution of species of Lasiocroton and Garciadelia. (a) Cuba; (b) the Bahamas; (c) Jamaica; (d) Hispaniola. The ultramafic massifs for Hispaniola (adapted from (adapted from Draper \& Barros, 1994, Draper et al., 1996, and Lewis et al., 2006) and Jamaica (adapted from Abbott et al., 1999 and Lewis et al., 2006) are labeled. Species coded as follows: $(\diamond)$ G. abbottii, ( $\square)$ G. castilloae, (П) G. leprosa,

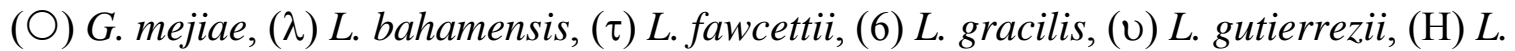
harrisii, and $(\sigma)$ L. microphyllus. Where L. bahamensis and L. microphyllus occur together, the symbols have been overlapped.

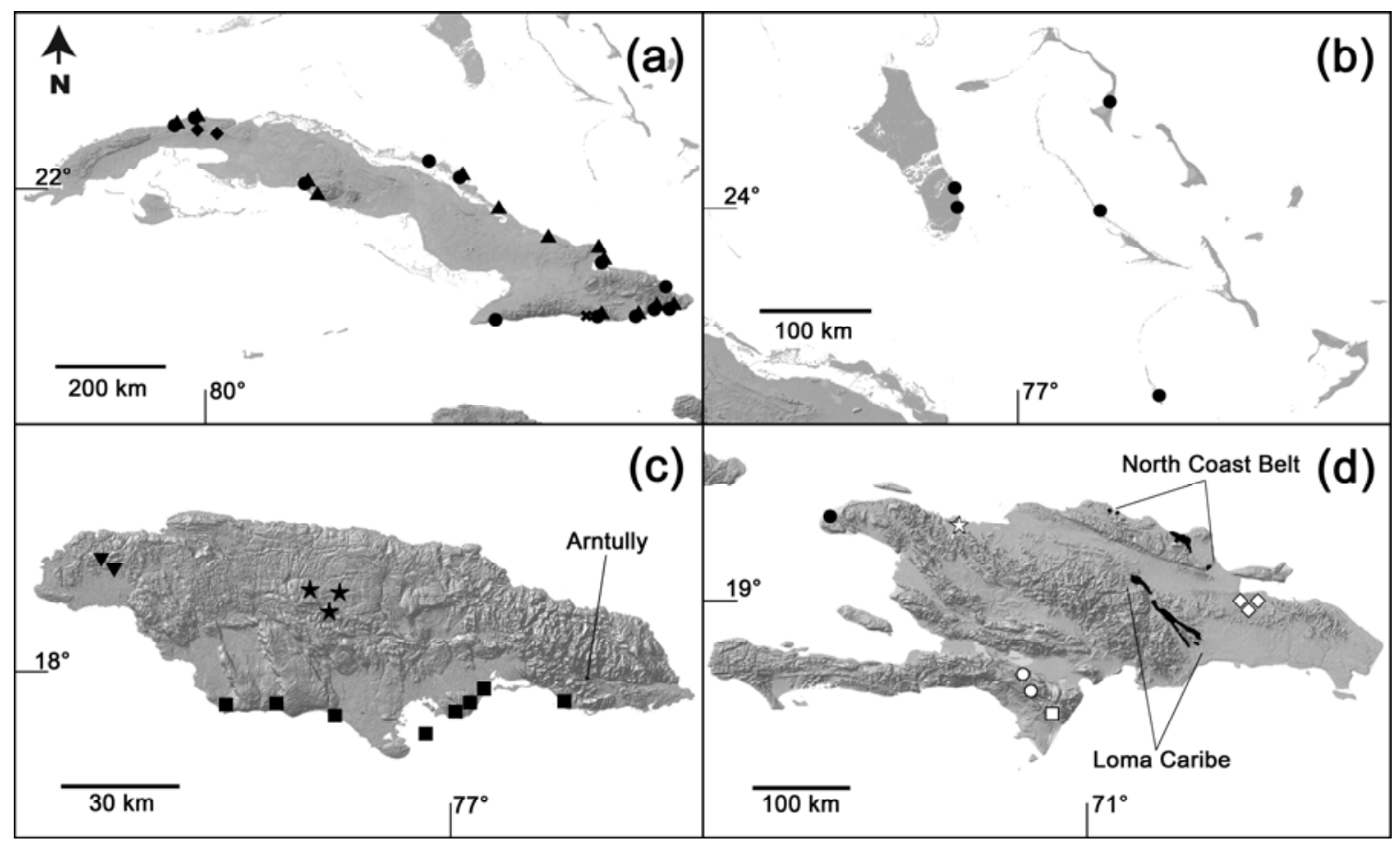


Figure 4 The strict consensus trees of the ITS and combined cpDNA datasets. Top topology, the ITS strict consensus tree of the 5880 most parsimonious trees. Bottom topology, the combined cpDNA strict consensus tree of the 6646 most parsimonious trees. Bootstrap values $(>50 \%)$ from parsimony analysis are above branches, clade credibility values from Bayesian analysis are below branches. For both analyses, support values of less than $50 \%$ are denoted with an asterisk. The two conflicts between the Bayesian and parsimony topologies (cpDNA data set) are indicated with "\#”.

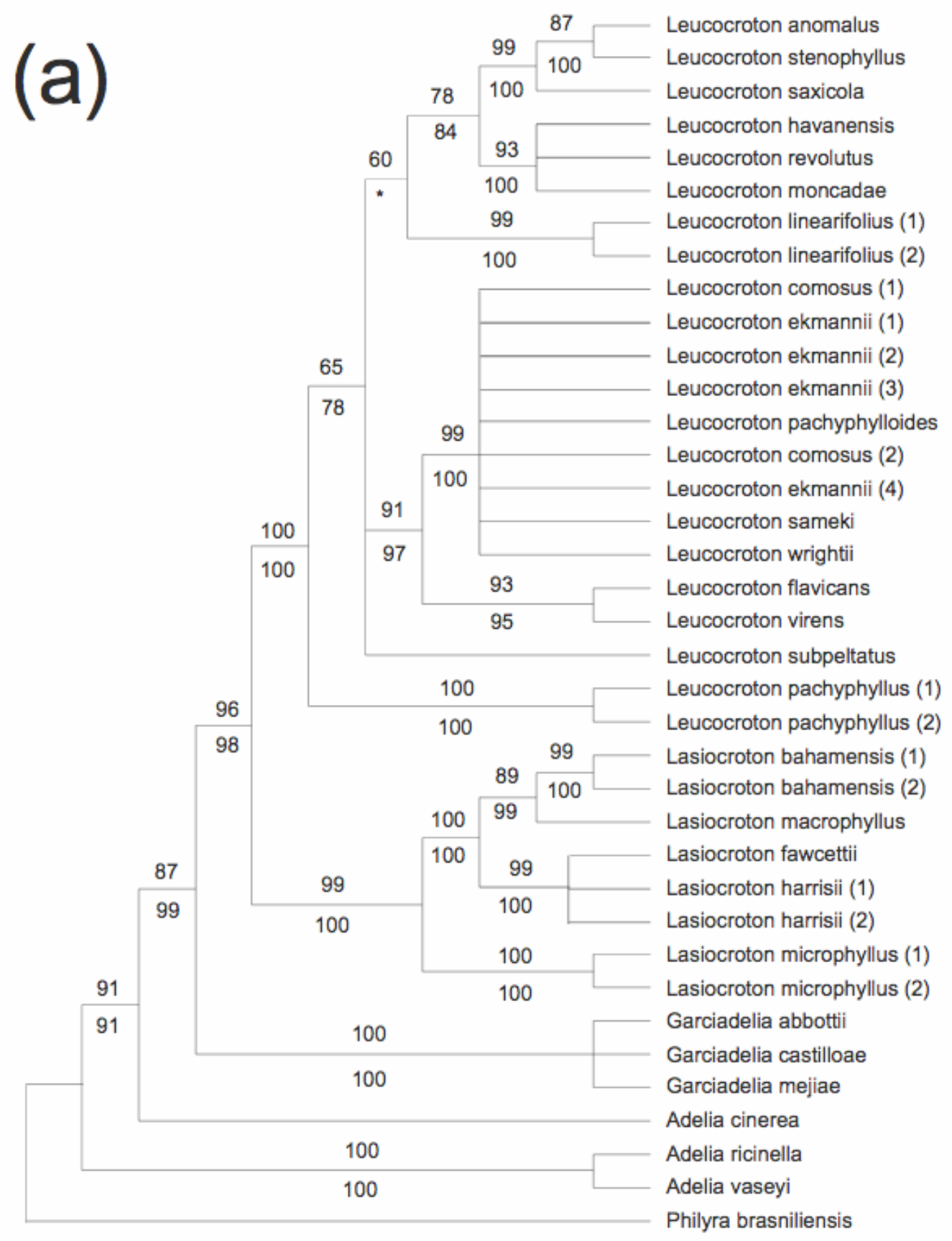




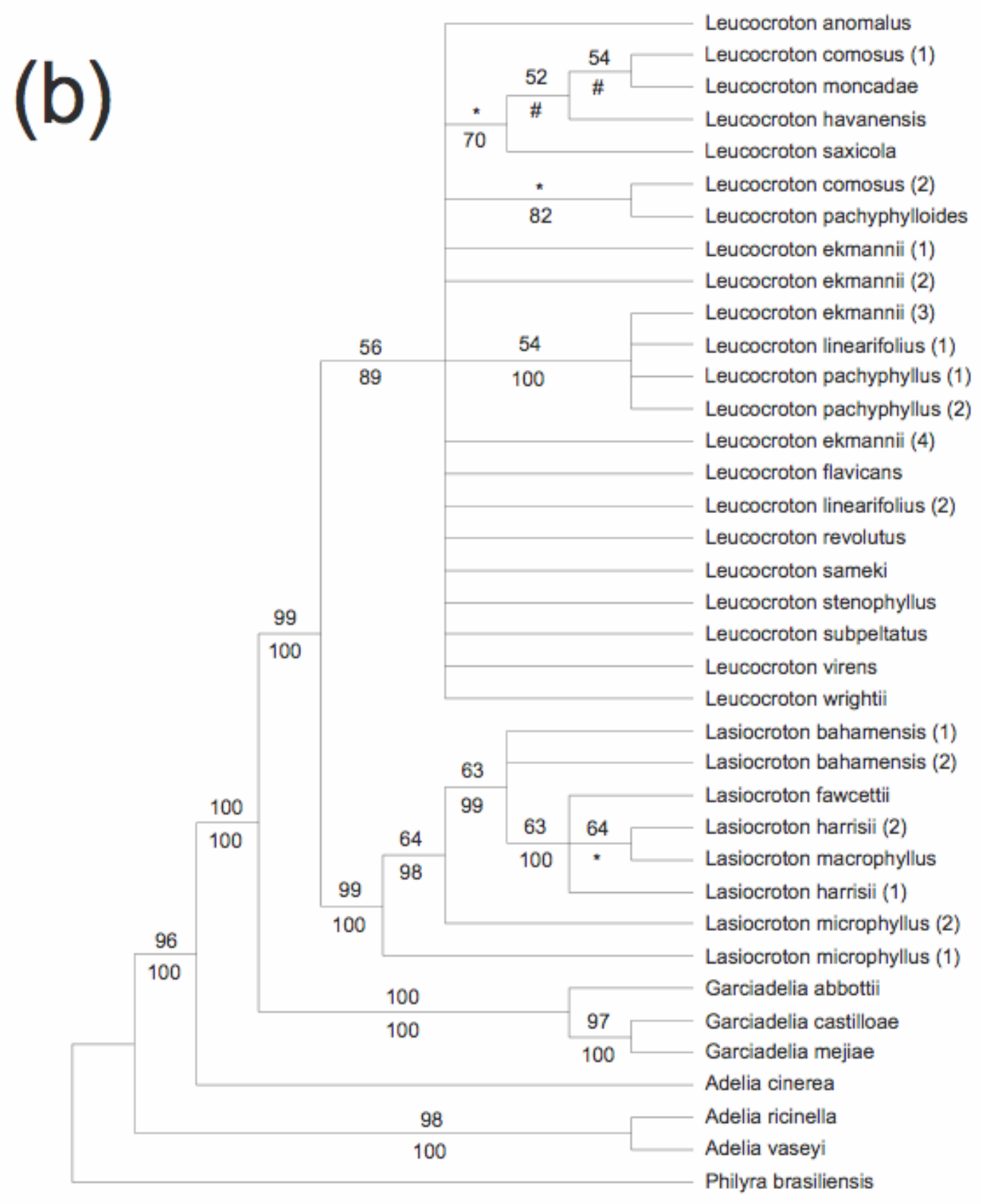


Figure 5 One of the twelve most parsimonious trees from the total combined ITScpDNA dataset. Bootstrap values ( $>50 \%)$ from parsimony analysis are above branches, clade credibility values from Bayesian analysis are below branches. Bootstrap values of less than $50 \%$ are denoted with an asterisk. The three conflicts between the Bayesian and parsimony topologies are indicated with "\#”. Number of steps along each branch are indicated in italics. The branch that collapses in the strict consensus tree is indicated with an arrow.

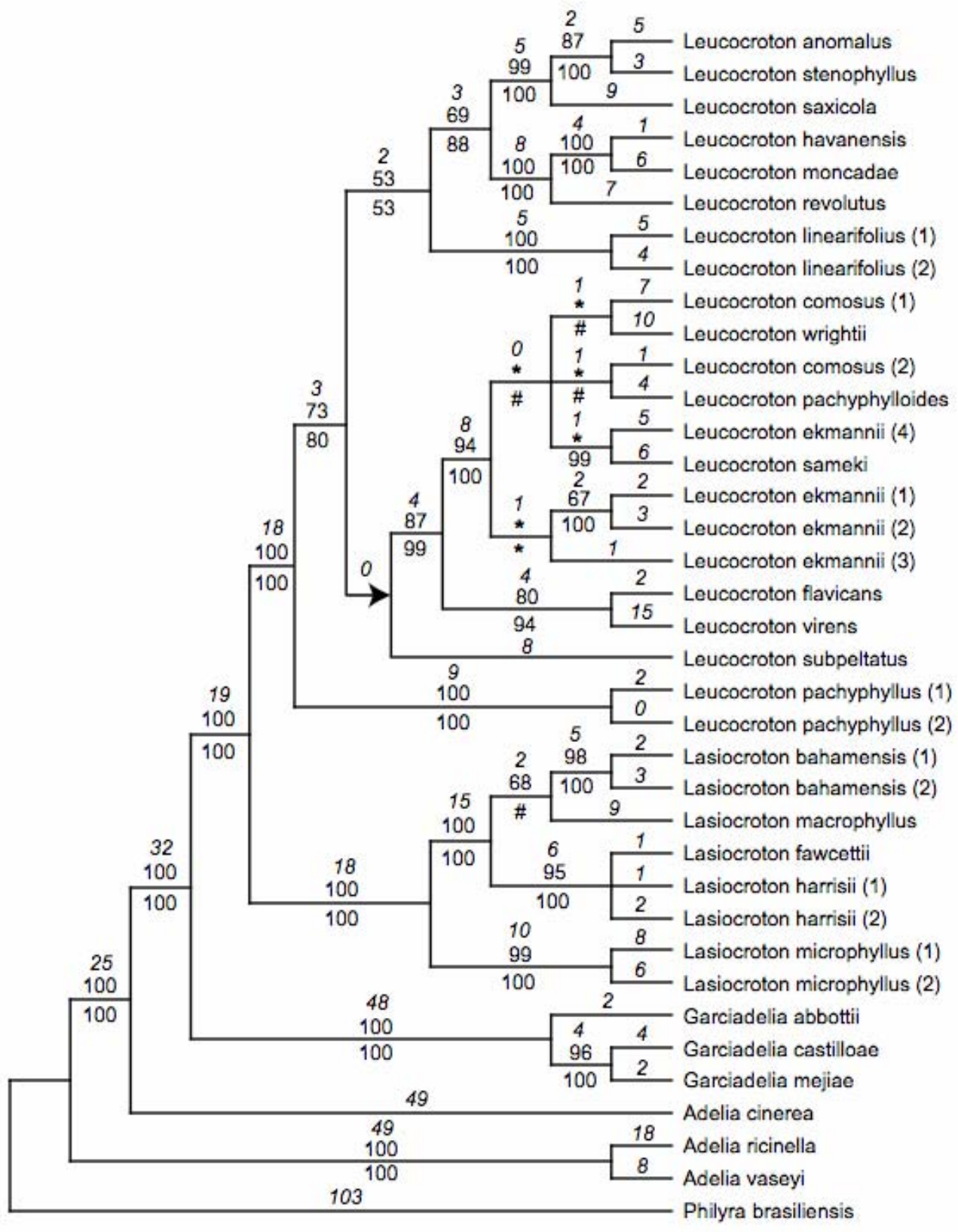


Figure 6 Reconstruction of ancestral areas using DIVA area analyses along topologies obtained after phylogenetic analyses of the ITS-cpDNA combined data set. Top topology, reconstruction along one of the most parsimonious trees yielded by parsimony. Bottom topology, reconstruction along one of the trees yielded by Bayesian inferences. Notice that the Bayesian tree only shows reconstructions along the Lasiocroton clade as the parsimony and Bayesian topologies were identical for the remaining branches.

(a)

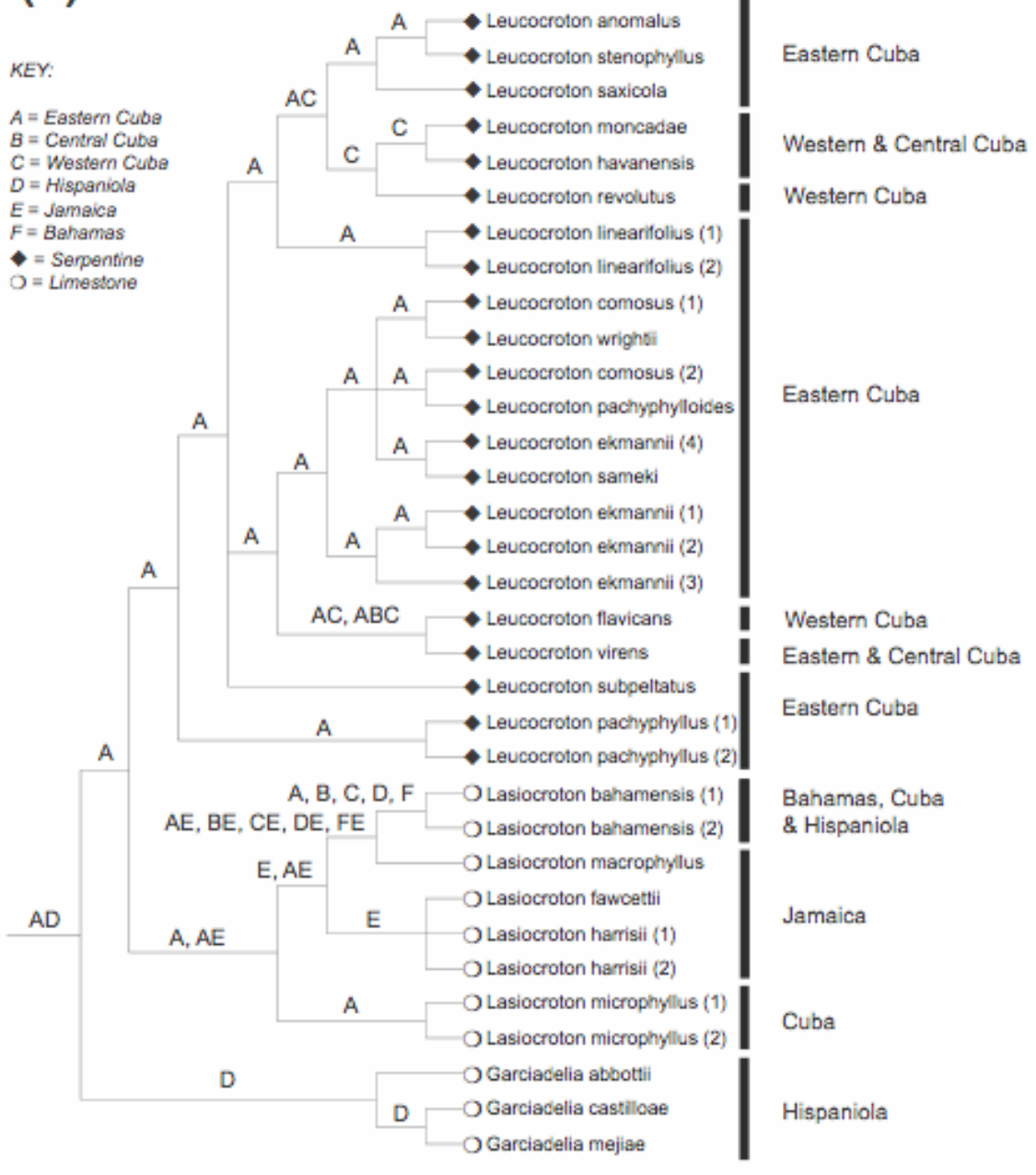

(b)

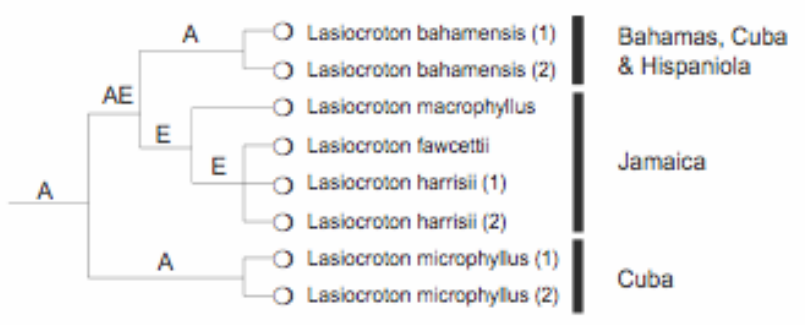


Table 1 Plant Collections: localities, collectors, and genbank numbers.

Species (reference \#)

Garciadelia abbottii Jestrow \& Jiménez Rodr.

Garciadelia castilloae Jestrow \& Jiménez Rodr.

Garciadelia mejiae Jestrow \& Jiménez Rodr.

Lasiocroton bahamensis Pax \& K.Hoffm. (1)

Lasiocroton bahamensis Pax \& K.Hoffm. (2)

Lasiocroton fawcettii Urb.

Lasiocroton harrisii Britton (1)

Lasiocroton harrisii Britton (2)

Lasiocroton macrophyllus (Sw.) Griseb.

Lasiocroton microphyllus (A.Rich.) Jestrow (1)

Lasiocroton microphyllus (A.Rich.) Jestrow (2)

Leucocroton anomalus Borhidi

Leucocroton comosus Urb. (1)

Leucocroton comosus Urb.(2)

Leucocroton ekmanii Urb. (1)

Leucocroton ekmanii Urb. (2)

Leucocroton ekmanii Urb. (3)

Leucocroton ekmanii Urb. (4)

Leucocroton flavicans Müll.Arg. in DC.

Leucocroton havanensis Borhidi

Leucocroton linearifolius Britton (1)
Collection Locality

Los Haitises, Hato Mayor, Hispaniola Sierra del Bahoruco, Barahona,

Hispaniola

Sierra del Bahoruco, Independencia,

Hispaniola

South Andros, Bahamas

Punta Macambo, Guantánamo, Cuba

Dolphin Head, Hanover, Jamaica

Peckham Woods, Clarendon, Jamaica

Aboukir, St. Ann, Jamaica

Hellshire Hills, St Catherine, Jamaica

Baitiquirí, Guantánamo, Cuba

Playa Caletica, Holguín, Cuba

Melones, Holguín, Cuba

Sierra de Nipe, Holguín, Cuba

Sierra de Nipe, Holguín, Cuba

near the base of Mina Iberia,

Guantánamo, Cuba

near the peak of Mina Iberia,

Guantánamo, Cuba

La Melba, Holguín, Cuba

Baracoa, Guantánamo, Cuba

Cajálbana, Pinar del Río, Cuba

Canasí, Matanzas, Cuba

La Melba, Holguín, Cuba
Genetic Voucher

GenBank (ITS, $p s b M-t r n D, y c f 6-p c b M)$

Jiménez 3577 (FTG)

Jestrow \& Jiménez 1020

(FTG)

Jestrow \& Jiménez 1018

(FTG)

GU000002 GU000041, GU000055

GU000008 GU000040, GU000053

GU000012 GU000039, GU000054

W. Gillis 10451 (ex situ FTBG)

HAJB 81950 (FTG)

Jestrow 1004 (FTG)

Jestrow 1009 (FTG)

Jestrow 1016 (FTG)

Jestrow 1002 (FTG)

HAJB 81947 (FTG)

HAJB 81839 (FTG)

HAJB 81831 (FTG)

Bennet 7608 (FTG)

HAJB 81722 (FTG)

HAJB 81859 (FTG)

HAJB 81864 (FTG)

HAJB 81794 FTG)

R. Oviedo 24/10/04 (HAC)

HAJB 81972 (FTG)

HAJB 82009 (FTG)

HAJB 81793 (FTG)
GU000024, GU000032, GU000056 HM223459, HM223460, HM223461 HM223462, HM223463, HM223464 GU000018, GU000033, GU000057 HM223465, HM223466, HM223467 HM185116, HM185117, HM185118 GU000017, GU000031, GU000058 HM223468, HM223469, HM223470

HM223471, HM223472, HM223473 HM223474, HM223475, HM223476 GU000020, GU000035, GU000059 HM223477, HM223478, HM223479 HM223480, HM223481, HM223482 HM223483, HM223484, HM223485 HM223486, HM223487, HM223488 HM223489, HM223490, HM223491 HM223492, HM223493, HM223494 HM223495, HM223496, HM223497 
Leucocroton linearifolius Britton (2)

Leucocroton moncadae Borhidi

Leucocroton pachyphylloides Borhidi

Leucocroton pachyphyllus Urb. (1)

Leucocroton pachyphyllus Urb. (2)

Leucocroton revolutus C.Wright in Sauvalle

Leucocroton sameki Borhidi

Leucocroton saxicola Britton

Leucocroton stenophyllus Urb.

Leucocroton subpeltatus (Urb.) Alain

Leucocroton virens Griseb.

Leucocroton wrightii Griseb.

Adelia cinerea (Wiggins \& Rollins) A.Cerv., V.W.Steinm. \& Flores Olv.

Adelia ricinella $\mathrm{L}$.

Adelia vaseyi (J.M.Coult.) Pax \& K.Hoffm.

Philyra brasiliensis Klotzsch.
La Melba, Holguín, Cuba

Loma de Coca, La Habana, Cuba

La Melba, Holguín, Cuba

Mina Iberia, Guantánamo, Cuba

La Melba, Holguín, Cuba

Cajálbana, Pinar del Río, Cuba

Yamanigüey, Holguín, Cuba

Sierra de Nipe, Holguín, Cuba

Sierra de Nipe, Holguín, Cuba

Sierra de Nipe, Holguín, Cuba

Baracoa, Guantánamo, Cuba

Moa, Holguín, Cuba

Sonora, Mexico

Guantánamo, Cuba

Tamaulipas, Mexico

Bahia, Brazil
HAJB 81807 (FTG)

HAJB 84363 (HAJB)

HAJB 81806 (FTG)

HAJB 81896 (FTG)

HAJB 81808 (FTG)

HAJB 81968 (FTG)

HAJB 81781 (FTG)

HAJB 81744 (FTG)

HAJB 81748 (FTG)

Bennet 7609 (FTG)

HAJB 81851 (FTG)

Bennet 7590 (FTG)

Steinmann 971 (RSA)

HAJB 81949 (FTG)

De Nova 191 (XAL)

Thomas et al. 12565 (NY)
GU000022, GU000038, GU000060

GU000021, GU000036, GU000061

HM223498, HM223499, HM223500

GU000019, GU000034, GU000062

HM223501, HM223502, HM223503

HM223504, HM223505, HM223506 HM223507, HM223508, HM223509 HM223510, HM223511, HM223512 HM223513, HM223514, HM223515 HM223516, HM223517, HM223518 GU000025, GU000037, GU000063 HM185119, HM185120, HM185121

GU000027, GU000042, GU000048

GU000023, GU000045, GU000049

GU000026, GU000043, GU000050 
Table 2 Parsimony statistics of trees and characters.

\begin{tabular}{cccccc}
\hline $\begin{array}{c}\text { DNA } \\
\text { Region }\end{array}$ & AL & Total PI & LA PI & MPT & CI/RI/RC \\
\hline \hline ITS & $678(15)$ & $135(10)$ & $109(5)$ & $5880(397)$ & $0.65 / 0.86 / 0.62$ \\
psbM-trnD & $1070(35)$ & $23(14)$ & $12(10)$ & $9870(102)$ & $0.79 / 0.91 / 0.82$ \\
& & & & & \\
$y c f 6-p c b M$ & $1204(25)$ & $35(13)$ & $27(10)$ & $236(99)$ & $0.74 / 0.88 / 0.73$ \\
\hline Chloroplast & $2274(60)$ & $58(27)$ & $39(20)$ & $6646(211)$ & $0.82 / 0.85 / 0.70$ \\
Total & $2952(75)$ & $193(37)$ & $148(25)$ & $12(624)$ & $0.64 / 0.85 / 0.63$ \\
\hline \hline
\end{tabular}

$\mathrm{AL}=$ alignment length (number of coded gaps); Total $\mathrm{PI}=$ total parsimony informative nucleotides (number of parsimony informative coded gaps); LA PI = parsimony informative nucleotides within the Leucocroton alliance (number of PI coded gaps); MPT $=$ number of most parsimonious trees (tree score); $\mathrm{CI} / \mathrm{RI} / \mathrm{RC}=$ consistency index excluding uninformative characters, retention index, and rescaled consistency index 
Table 3 Bremer's Ancestral Areas Analysis for the Leucocroton alliance clade according to both parsimony and Bayesian topologies. The asterisks denote the Bremer values with Lasiocroton bahamensis scored as absent from Hispaniola.

\begin{tabular}{lcccc} 
Parsimony & \multicolumn{1}{l}{ G } & L & G/L & AA \\
\hline \hline Eastern Cuba & 7 & 5 & 1.40 & 1.00 \\
Central Cuba & 4 & 10 & 0.40 & 0.29 \\
Western Cuba & 4 & 8 & 0.50 & 0.36 \\
Hispaniola & 2 & 4 & 0.50 & 0.36 \\
Jamaica & 2 & 4 & 0.50 & 0.36 \\
Bahamas & 1 & 5 & 0.20 & 0.10 \\
\hline Hispaniola* & 1 & 1 & 1.00 & 0.50 \\
\hline \hline
\end{tabular}

Bayesian

\begin{tabular}{ccccc}
\hline & G & L & G/L & AA \\
\hline \hline Eastern Cuba & 7 & 4 & 1.75 & 1.00 \\
Central Cuba & 4 & 7 & 0.57 & 0.33 \\
Western Cuba & 4 & 7 & 0.57 & 0.33 \\
Hispaniola & 2 & 3 & 0.67 & 0.38 \\
Jamaica & 1 & 4 & 0.25 & 0.14 \\
Bahamas & 1 & 4 & 0.25 & 0.14 \\
\hline Hispaniola* & 1 & 1 & 1.00 & 0.57 \\
\hline \hline
\end{tabular}


Table 4 The Bremer Ancestral Areas Analysis for the Lasiocroton clade according to both parsimony and bayesian topologies.

\begin{tabular}{ccccc} 
Parsimony & & & & \\
\hline Eastern Cuba & G & L & G/L & AA \\
Central Cuba & 2 & 2 & 1 & 1 \\
Western Cuba & 2 & 2 & 1 & 1 \\
Hispaniola & 1 & 2 & 1 & 1 \\
Jamaica & 2 & 2 & 0.33 & 0.33 \\
Bahamas & 1 & 3 & 0.33 & 1 \\
\hline \hline
\end{tabular}

\begin{tabular}{lllcc} 
Bayesian & & & & \\
\hline \hline Eastern Cuba & G & L & G/L & AA \\
Central Cuba & 2 & 1 & 2 & 1 \\
Western Cuba & 2 & 1 & 2 & 1 \\
Hispaniola & 1 & 1 & 2 & 1 \\
Jamaica & 1 & 2 & 0.5 & 0.25 \\
Bahamas & 1 & 2 & 0.5 & 0.25 \\
\hline \hline
\end{tabular}




\section{CHAPTER IV}

\section{CONCLUSION AND FUTURE RESEARCH DIRECTIONS}

- Combined phylogenetic analyses of trnL-F and $r b c L$ showed that the critically endangered Jamaican endemic, Lasiocroton trelawniensis (Euphorbiaceae; Adelieae) belongs to the genus Bernardia. Pollen SEM and macromorphological characters further support the finding. Bernardia trelawniensis (C.D. Adams) Jestrow \& G.R. Proctor is a new taxonomic combination, placing the species in a different tribe. The new placement explains many of the previously misunderstood morphological characters (e.g., denticulate margins), which suggested that the species underwent significant evolutionary change. The placement in Bernardia now shows a species closely related the type of the genus,

B. dichotoma, a taxon widely distributed across the Greater Antilles. My investigation further found that Bernardia dichotoma poses a possible species complex including, not only B. trelawniensis but, other varieties and synonyms from varying elevations of different islands. Further phylogenetic and population genetic studies are required to unravel the relationships of these Caribbean Bernardia.

- Members of the Adelieae, along with outgroups from neighboring tribes, were included in phylogenetic analyses of both chloroplast (i.e., psbM-trnD and ycf6$p c b M$ ) and nuclear (i.e., ITS) regions. This showed that the Caribbean genera, Lasiocroton and Leucocroton were not monophyletic in respect to each other because of two species of Leucocroton. One of these was moved to Lasiocroton as Lasiocroton microphyllus, a taxonomic change further supported by 
morphological characters (e.g. thick pistillate disk). The other species was found to represent ancestral lineage before the dichotomization of the two genera. This species, formally recognized as Leucocroton leprosus, was described as the basis of the new genus, Garciadelia. The separation of these two species from Leucocroton now defines the genus as a nickel hyperaccumulators, endemic to the serpentine areas of Cuba. As no other members of the tribe either occur on serpentine or hyperaccumulate nickel, this genus provides an example of an isolated evolutionary development towards heavy metal tolerance. As genetic methods improve, the identification of this radiation provides an ideal project into the physiology of heavy metal tolerance.

- The genus Garciadelia was published based on the aforementioned species, Garciadelia leprosa. This formed, together with Lasiocroton and Leucocroton, a monophyletic assemblage of three genera endemic to the Caribbean Islands, now known as the Leucocroton-alliance Furthermore three new species of differing morphologies and from disparate localities were described. The genus is endemic to Hispaniola, and all species were classified according to the IUCN guidelines. The possibility of gene flow between these species is not supported by the phylogeny. As all species of the genus are represented by few individuals, the level of inbreeding depression is a concern. The genus represents an ideal subject of population genetics for critically endangered taxa of the Caribbean.

- The species Lasiocroton gutierrezii was described from two historical collections previously identified as Lasiocroton microphyllus. Unlike L. microphyllus, the new species is found on an upland habitat and is differentiable both by sterile 
(e.g., lack of stem spines) and fertile (e.g., many flowered pistillate inflorescence) structures. Publishing this species bring attention to the field botanists of Cuba, in order to recollect this presumably rare species. If found, the two closely related species would be an ideal subject both for a common garden experiment and a genetic investigation to determine the genetic and phenotypic differences between these taxonomic entities.

- The historical biogeography of the Leucocroton-alliance was studied based on phylogenetic analyses of the same gene regions, though with a more rigorous sampling of taxa. Bremer and DIVA algorithms were used to reconstruct the ancestral areas. The alliance arose on Eastern Cuba and Hispaniola, with Garciadelia separating from the Lasiocroton-Leucocroton clade as a vicariant event. This suggests a time of divergence of $\sim 15 \mathrm{Ma}$, though a later dispersal is still a possibility. Fossils are unknown within the alliance, however future studies of the Dominican amber lagerstätte could provide relevant pollen specimens for the dating of nodes.

- Lasiocroton and Leucocroton arose on Eastern Cuba. Lasiocroton dispersed across Cuba and also eventually to the Bahamas and Jamaica. The low elevation species of Jamaica, L. macrophyllus, represents a link between those of upland Jamaican and those of the Bahamas and Cuba. Within Leucocroton, two separate clades of the genus have representatives in Western Cuba. This gives evidence of two westward migrations across the serpentine islands of Cuba. While my phylogeny gave no evidence of hybridization, the species boundaries of the genus 
require further investigation. This is could be approached through both population genetics, as well as a detailed field study of extant populations. 
VITA

\section{BRETT ANTHONY JESTROW}

March $12^{\text {th }}, 1979$

2002

2008

\section{PUBLICATIONS}

Jestrow, B., G. Proctor, and Francisco-Ortega. 2008. Lasiocroton trelawniensis (Euphorbiaceae), a critically endangered species from the cockpit country of Jamaica, belongs to Bernardia (Euphorbiaceae). Botanical Review 74: 166-177

Jestrow, B., F. Jiménez, and J. Francisco-Ortega. In press. Generic delimitation in the Antillean Adelieae (Euphorbiaceae) with the description of the Hispaniolan endemic genus Garciadelia. Taxon.

Jestrow, B., J.E. Gutiérrez Amaro, and J. Francisco-Ortega. In preparation. Islands within Islands; a plant radiation across the serpentine archipelago of Cuba. Journal of Biogeography.

\section{PRESENTATIONS}

Jestrow, B. (2006) Seminar held at the Fairchild Tropical Botanic Garden. "Phylogenetics, conservation, and historical biogeography of the West Indian genera Lasiocroton and Leucocroton (Euphorbiaceae)."

Jestrow, B. (2006) Poster presented at the annual EPA GRO-STAR Fellowship Conference. "Phylogenetics, conservation, and historical biogeography of the West Indian genera Lasiocroton and Leucocroton (Euphorbiaceae)."

Jestrow, B. Oral presentation delivered at the Botanical Society of America and American Society of Plant Taxonomists meeting in Chico, California. Jestrow, B., J. Francisco-Ortega, J. Gutierrez, and P. Berry. "Phylogenetics, conservation, and historical biogeography of the West Indian genera Lasiocroton and Leucocroton (Euphorbiaceae)." 
van Ee, B.W. (2006) Oral presentation co-authored at the Ninth Congreso Latinoamericano de Botánica, Jardín Botanico Nacional, Santo Domingo, República Dominicana. Berry, P. E., J.Francisco-Ortega, J. E. Gutierrez, B. Jestrow, W. van Ee. "Avances moleculares recientes de tres generos de Euphorbiaceae, en las Antillas: Croton, Euphorbia, y Leucocroton."

Jestrow, B. (2007) Oral presentation delivered at the Ninth Annual Biology Symposium. Jestrow, B., G. Proctor, and J. Francisco-Ortega. "Lasiocroton trelawniensis (Euphorbiaceae), a critically endangered species from the cockpit country of Jamaica, belongs to Bernardia (Euphorbiaceae)."

Jestrow, B. (2008) Oral presentation delivered at the Tenth Annual Biology Symposium. Jestrow, B. "Phylogenetic relationships within the tribe Adelieae (Euphorbiaceae)."

Jestrow, B. (2010) Oral presentation delivered at the Botanical Society of America and American Society of Plant Taxonomists meeting in Providence, Rhode Island. Jestrow, B., J. Gutierrez, and J. Francisco-Ortega. "Islands within Islands; a radiation across the serpentine archipelago of Cuba." 